\title{
The UMIST database for astrochemistry 1995^
}

\author{
T.J. Millar, P.R.A. Farquhar and K. Willacy \\ Department of Physics, UMIST, P.O. Box 88, Manchester, M60 1QD, UK
}

Received February 12; accepted May 14, 1996

\begin{abstract}
We report the release of a new version of the UMIST database for astrochemistry. The database contains the rate coefficients of 3864 gas-phase reactions important in interstellar and circumstellar chemistry and involves 395 species and 12 elements. The previous (1990) version of this database has been widely used by modellers. In addition to the rate coefficients, we also tabulate permanent electric dipole moments of the neutral species and heats of formation. A numerical model of the chemical evolution of a dark cloud is calculated and important differences to that calculated with the previous database noted.
\end{abstract}

Key words: ISM: molecules - molecular data molecular processes

\section{Introduction}

To date, over 100 molecules have been detected in interstellar and circumstellar regions (Table 1), and detailed models of chemical synthesis have been developed for dark clouds (Hasegawa \& Herbst 1993; Herbst et al. 1994; Bergin et al. 1995; Neufeld et al. 1995; Mackay 1996), hot molecular cores (Charnley et al. 1992; Charnley et al. 1995; MacKay 1995), circumstellar envelopes (Cherchneff et al. 1993; Cherchneff \& Glassgold 1993; Millar \& Herbst 1994), and Photon-Dominated Regions (Sternberg \& Dalgarno 1995). Many of these have used data from previous releases of the UMIST database (Millar et al. 1991b; Farquhar \& Millar 1993), as have modellers of comet chemistry (Eberhardt et al. 1994; Meier et al. 1993, 1994; Eberhardt \& Krankowsky 1995; Altwegg et al. 1994). In this paper, we report on our latest release of the UMIST database which has been extended to include rate coefficients on 3864 reactions among 395 species and 12 elements with neutral molecules containing up to 12 atoms $\left(\mathrm{CH}_{3} \mathrm{C}_{7} \mathrm{~N}\right)$ and represents an increase of around one-third on the 1990 version (Millar et al. 1991b).

Send offprint requests to: T.J. Millar

* Table 4 also available in electronic form at CDS
Section 2 contains a summary of the information contained in the species file and on related information such as electric dipole moments and heats of formation. Section 3 presents the rate coefficients and discusses the important changes made for this update, while Sect. 4 contains the results of a time-dependent calculation of a dense cloud model. Finally, Sect. 5 describes how the data may be obtained.

\section{The species and related data}

Our species set, given in Table 2, contains 395 atomic and molecular species involving the 12 elements $\mathrm{H}, \mathrm{He}, \mathrm{C}, \mathrm{N}$, $\mathrm{O}, \mathrm{Na}, \mathrm{Mg}, \mathrm{Si}, \mathrm{P}, \mathrm{S}, \mathrm{Cl}$ and $\mathrm{Fe}$. The species are ordered by number of atoms, with a sub-ordering given by the number of $\mathrm{H}$ atoms, followed by the number of $\mathrm{C}$ atoms they contain. For computational convenience, some species are written in 'shorthand', for example, $\mathrm{C}_{5} \mathrm{H}_{4}$ represents methyl diacetylene, $\mathrm{CH}_{3} \mathrm{C}_{4} \mathrm{H}$. We have included neutrals with up to 12 atoms. In such cases, the proper chemical formula is contained in parentheses after the 'shorthand' in Table 3 which lists the permanent electric dipole moments of the neutral species. Table 2 also lists the heats of formation of the species contained in the reaction set and can be used to check whether particular reactions are exothermic or endothermic. These data, which were mostly provided by H.-H. Lee (Ohio State University), have been used to exclude a number of highly endothermic ion-neutral reactions which were in the 1990 ratefile. Endothermic neutral-neutral reactions are still contained in this release because such reactions are important in shocked gas; ion-neutrals are relatively unimportant here, although those which are important, for example the reactions of $\mathrm{H}_{n} \mathrm{~S}^{+}(n=0-2)$ with $\mathrm{H}_{2}$ which initiate sulfur chemistry in shocked gas, are included.

The permanent electric dipole moments for the 137 neutral molecules contained in the species set are given, where available, in Table 3 . The rate file distinguishes between some isomers, such as HCN and HNC, as well as $\mathrm{C}_{2} \mathrm{H}_{5} \mathrm{OH}$ and $\mathrm{CH}_{3} \mathrm{OCH}_{3}$, and the dipole moments are listed for each isomer. In those cases in which the ratefile does not distinguish isomers, for example, the various forms of linear and cyclic $\mathrm{C}_{3} \mathrm{H}, \mathrm{C}_{3} \mathrm{H}_{2}$ and $\mathrm{C}_{4} \mathrm{H}_{2}$, the dipole 
Table 1. Observed interstellar and circumstellar molecules as of December 1995

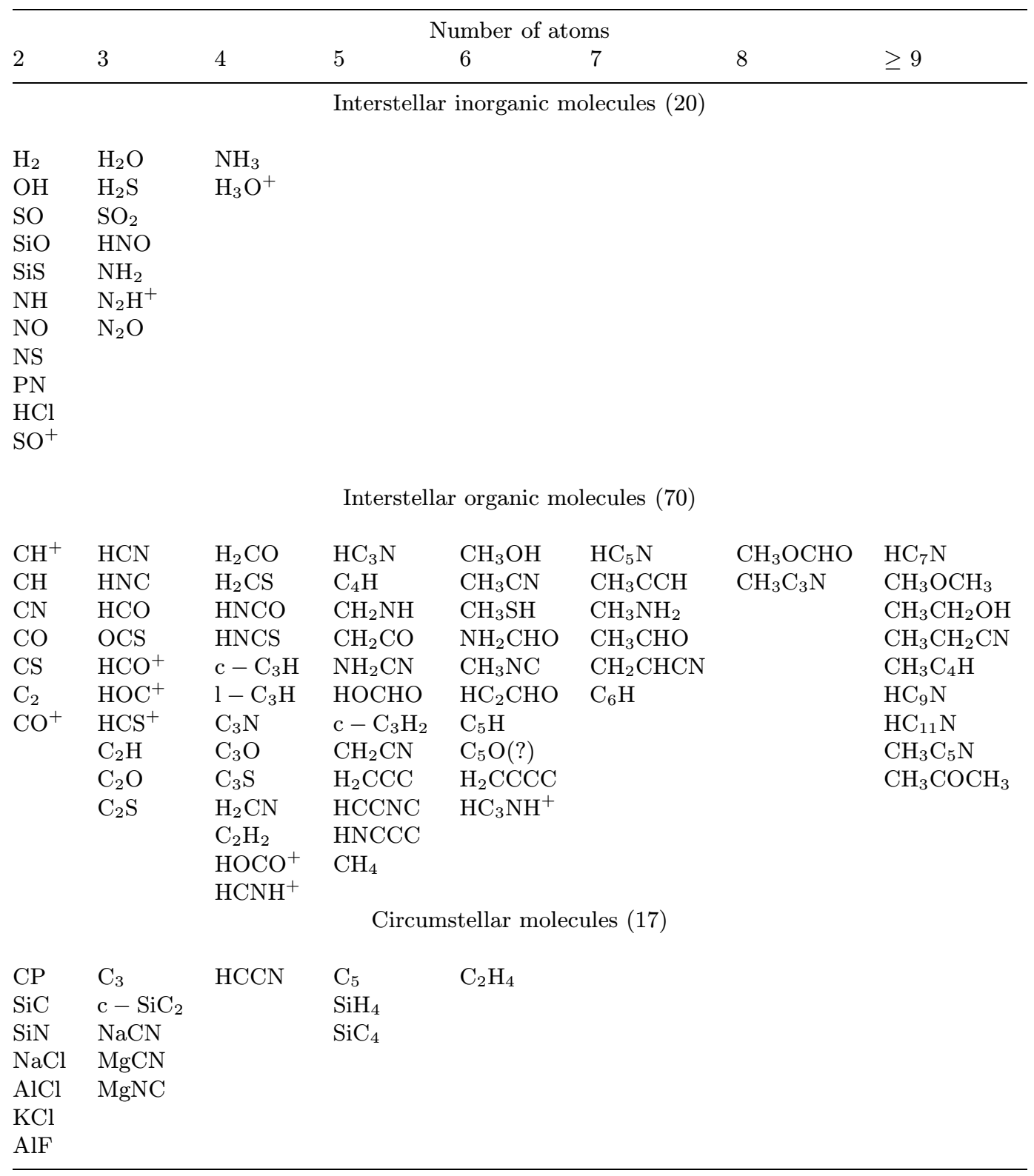

moments for each form are given. The electric dipole moments are important for calculating reaction rate coefficients appropriate for low temperatures $(T<50 \mathrm{~K})$. Various formulae have been suggested, based on theoretical and experimental approaches (Adams \& Smith 1987; Troe 1987; Herbst \& Leung 1986).

\section{The reaction set}

Table 4 contains the fundamental rate coefficient data. In this section, we discuss the general form of the data, describe the format of each entry, discuss particular reac- tions or class of reactions and describe major differences since the 1990 release.

\subsection{General form}

The reactions and associated rate coefficients can be divided up into a number of categories, each of which has been ordered in terms of the mass number of the first reactant, and for a specific first reactant in terms of increasing mass number for the second reactant. The ratefile is organised as follows:

- Reactions 1 - 394. Neutral-neutral reactions. 
Table 2. Species and heats of formation in $\mathrm{kJ} \mathrm{mol}^{-1}$ at $0 \mathrm{~K}$

\begin{tabular}{|c|c|c|c|c|c|c|c|c|c|}
\hline $\mathrm{H}$ & 216.0 & $\mathrm{HE}$ & 0.0 & $\mathrm{C}$ & 711.2 & $\mathrm{~N}$ & 470.8 & $\mathrm{O}$ & 246.8 \\
\hline NA & 107.6 & MG & 146.5 & SI & 446.0 & $\mathrm{P}$ & 315.6 & $\mathrm{~S}$ & 274.7 \\
\hline CL & 119.6 & $\mathrm{FE}$ & 414.0 & $\mathrm{H} 2$ & 0.0 & $\mathrm{CH}$ & 592.5 & $\mathrm{NH}$ & 376.5 \\
\hline $\mathrm{OH}$ & 38.4 & $\mathrm{SIH}$ & 374.9 & $\mathrm{PH}$ & 237.0 & HS & 136.5 & HCL & -92.1 \\
\hline $\mathrm{C} 2$ & 817.0 & $\mathrm{CN}$ & 436.8 & $\mathrm{CO}$ & -113.8 & SIC & 734.7 & $\mathrm{CP}$ & 516.0 \\
\hline CS & 262.0 & CCL & 384.0 & $\mathrm{~N} 2$ & 0.0 & $\mathrm{NO}$ & 90.8 & SIN & 485.0 \\
\hline PN & 106.0 & NS & 263.0 & $\mathrm{O} 2$ & 0.0 & $\mathrm{SIO}$ & -101.6 & $\mathrm{PO}$ & -32.0 \\
\hline $\mathrm{SO}$ & 5.0 & $\mathrm{CLO}$ & 101.8 & SIS & $\ldots \ldots$ & $\mathrm{S} 2$ & 128.3 & $\mathrm{CH} 2$ & 390.0 \\
\hline NH2 & 191.6 & $\mathrm{H} 2 \mathrm{O}$ & -238.9 & SIH2 & 289.0 & PH2 & 142.2 & $\mathrm{H} 2 \mathrm{~S}$ & -17.6 \\
\hline $\mathrm{C} 2 \mathrm{H}$ & 560.0 & $\mathrm{HCN}$ & 135.5 & $\mathrm{HNC}$ & 201.0 & $\mathrm{HCO}$ & 44.8 & HCSI & $\ldots \ldots$ \\
\hline $\mathrm{HCP}$ & 167.0 & HCS & 310.0 & $\mathrm{HNO}$ & 100.0 & HNSI & 162.8 & $\mathrm{O} 2 \mathrm{H}$ & 13.4 \\
\hline $\mathrm{HPO}$ & $\ldots \ldots$ & HS2 & $\ldots \ldots$ & C3 & 831.0 & $\mathrm{CCN}$ & 556.0 & $\mathrm{CCO}$ & $\ldots \ldots$ \\
\hline SIC2 & 610.0 & $\mathrm{CCP}$ & $\ldots \ldots$ & $\mathrm{C} 2 \mathrm{~S}$ & $\ldots \ldots$ & $\mathrm{OCN}$ & 154.0 & SINC & $\ldots \ldots$ \\
\hline $\mathrm{CO} 2$ & -393.1 & OCS & -142.0 & $\mathrm{~N} 2 \mathrm{O}$ & 85.5 & NO2 & 36.0 & SIO2 & -281.2 \\
\hline $\mathrm{SO} 2$ & -294.3 & CH3 & 149.0 & NH3 & -38.9 & SIH3 & 202.9 & $\mathrm{C} 2 \mathrm{H} 2$ & 228.6 \\
\hline $\mathrm{H} 2 \mathrm{O} 2$ & -130.0 & $\mathrm{H} 2 \mathrm{~S} 2$ & 16.0 & $\mathrm{H} 2 \mathrm{CN}$ & 189.0 & $\mathrm{H} 2 \mathrm{CO}$ & -104.7 & SICH2 & $\ldots \ldots$ \\
\hline $\mathrm{H} 2 \mathrm{CS}$ & 105.0 & H2SIO & $\ldots \ldots$ & $\mathrm{C} 3 \mathrm{H}$ & 602.5 & $\mathrm{SIC} 2 \mathrm{H}$ & $\ldots \ldots$ & $\mathrm{HCCP}$ & $\ldots \ldots$ \\
\hline $\mathrm{C} 4$ & 1052.0 & $\mathrm{C} 3 \mathrm{~N}$ & $\ldots \ldots$ & $\mathrm{C} 3 \mathrm{O}$ & $\ldots \ldots$ & SIC3 & $\ldots \ldots$ & $\mathrm{C} 3 \mathrm{P}$ & $\ldots \ldots$ \\
\hline C3S & $\ldots \ldots$ & $\mathrm{CH} 4$ & -66.8 & SIH4 & 46.0 & $\mathrm{C} 2 \mathrm{H} 3$ & 262.2 & $\mathrm{CH} 2 \mathrm{NH}$ & $\ldots \ldots$ \\
\hline SICH3 & $\ldots \ldots$ & $\mathrm{CH} 2 \mathrm{PH}$ & $\ldots \ldots$ & $\mathrm{H} 2 \mathrm{C} 3$ & 512.0 & $\mathrm{C} 3 \mathrm{H} 2$ & $\ldots \ldots$ & $\mathrm{CH} 2 \mathrm{CN}$ & 245.0 \\
\hline $\mathrm{CH} 2 \mathrm{CO}$ & -44.6 & SIC2H2 & $\ldots \ldots$ & $\mathrm{CHOOH}$ & -378.8 & $\mathrm{C} 4 \mathrm{H}$ & $\ldots \ldots$ & $\mathrm{HC} 3 \mathrm{~N}$ & 351.0 \\
\hline SIC3H & $\ldots \ldots$ & C5 & 1081.0 & SIC4 & $\ldots \ldots$ & $\mathrm{C} 4 \mathrm{P}$ & $\ldots \ldots$ & $\mathrm{C} 4 \mathrm{~S}$ & $\ldots \ldots$ \\
\hline $\mathrm{C} 2 \mathrm{H} 4$ & 60.7 & CH3OH & -190.7 & $\mathrm{C} 3 \mathrm{H} 3$ & 343.0 & $\mathrm{CH} 3 \mathrm{CN}$ & 81.0 & $\mathrm{C} 4 \mathrm{H} 2$ & 440.0 \\
\hline $\mathrm{C} 5 \mathrm{H}$ & $\ldots \ldots$ & C6 & 1312.0 & $\mathrm{C} 5 \mathrm{~N}$ & $\ldots \ldots$ & $\mathrm{C} 2 \mathrm{H} 5$ & 130.0 & $\mathrm{C} 3 \mathrm{H} 4$ & 195.1 \\
\hline CH3CHO & -155.0 & H3C3N & 184.0 & $\mathrm{C} 5 \mathrm{H} 2$ & 723.0 & $\mathrm{C} 6 \mathrm{H}$ & $\ldots \ldots$ & $\mathrm{HC} 5 \mathrm{~N}$ & $\ldots \ldots$ \\
\hline $\mathrm{C} 7$ & 1325.0 & $\mathrm{C} 2 \mathrm{H} 6$ & -69.1 & НСOOCH3 & -355.5 & $\mathrm{H} 3 \mathrm{C} 4 \mathrm{~N}$ & 338.0 & $\mathrm{C} 6 \mathrm{H} 2$ & 652.0 \\
\hline $\mathrm{C} 7 \mathrm{H}$ & $\ldots \ldots$ & $\mathrm{C} 8$ & 1487.0 & $\mathrm{C} 7 \mathrm{~N}$ & $\ldots \ldots$ & CH3OCH3 & -166.3 & $\mathrm{C} 2 \mathrm{H} 5 \mathrm{OH}$ & -217.1 \\
\hline $\mathrm{C} 5 \mathrm{H} 4$ & 425.0 & $\mathrm{C} 7 \mathrm{H} 2$ & 933.0 & $\mathrm{C} 8 \mathrm{H}$ & $\ldots \ldots$ & $\mathrm{HC} 7 \mathrm{~N}$ & $\ldots \ldots$ & $\mathrm{C} 9$ & 1554.0 \\
\hline C2H6CO & -217.2 & $\mathrm{H} 3 \mathrm{C} 6 \mathrm{~N}$ & $\ldots \ldots$ & $\mathrm{C} 8 \mathrm{H} 2$ & 864.0 & $\mathrm{C} 9 \mathrm{H}$ & $\ldots \ldots$ & $\mathrm{C} 9 \mathrm{~N}$ & $\ldots \ldots$ \\
\hline $\mathrm{C} 7 \mathrm{H} 4$ & $\ldots \ldots$ & $\mathrm{C} 9 \mathrm{H} 2$ & 1142.0 & $\mathrm{HC} 9 \mathrm{~N}$ & $\ldots \ldots$ & $\mathrm{H} 3 \mathrm{C} 8 \mathrm{~N}$ & $\ldots \ldots$ & $\mathrm{H}-$ & 143.2 \\
\hline $\mathrm{C}-$ & $\ldots \ldots$ & O- & 105.4 & S- & 75.0 & $\mathrm{OH}-$ & -137.7 & $\mathrm{CN}-$ & 63.6 \\
\hline $\mathrm{H}+$ & 1528.0 & $\mathrm{HE}+$ & 2372.0 & $\mathrm{C}+$ & 1797.6 & $\mathrm{~N}+$ & 1873.1 & $\mathrm{O}+$ & 1560.7 \\
\hline $\mathrm{NA}+$ & 603.4 & $\mathrm{MG}+$ & 884.2 & $\mathrm{SI}+$ & 1233.0 & $\mathrm{P}+$ & 1328.0 & $\mathrm{~S}+$ & 1272.0 \\
\hline $\mathrm{CL}+$ & 1371.0 & $\mathrm{FE}+$ & 1173.0 & $\mathrm{H} 2+$ & 1488.3 & $\mathrm{HEH}+$ & 1352.0 & $\mathrm{CH}+$ & 1619.1 \\
\hline $\mathrm{NH}+$ & 1678.1 & $\mathrm{OH}+$ & 1292.7 & $\mathrm{SIH}+$ & 1136.2 & $\mathrm{PH}+$ & 1219.0 & $\mathrm{HS}+$ & 1137.0 \\
\hline HCL+ & 1137.7 & $\mathrm{C} 2+$ & 1992.0 & $\mathrm{CN}+$ & 1796.3 & $\mathrm{CO}+$ & 1238.3 & $\mathrm{SIC}+$ & $\ldots \ldots$ \\
\hline $\mathrm{CP}+$ & 1529.0 & $\mathrm{CS}+$ & 1356.0 & $\mathrm{CCL}+$ & 1243.0 & $\mathrm{~N} 2+$ & 1503.3 & $\mathrm{NO}+$ & 984.7 \\
\hline $\mathrm{SIN}+$ & $\ldots \ldots$ & $\mathrm{PN}+$ & 1249.0 & $\mathrm{NS}+$ & 1119.0 & $\mathrm{O} 2+$ & 1164.7 & $\mathrm{SIO}+$ & 1001.2 \\
\hline $\mathrm{PO}+$ & 778.0 & $\mathrm{SO}+$ & 1000.7 & $\mathrm{CLO}+$ & 1158.0 & SIS+ & $\ldots \ldots$ & $\mathrm{S} 2+$ & 1031.0 \\
\hline $\mathrm{H} 3+$ & 1107.0 & $\mathrm{CH} 2+$ & 1386.0 & $\mathrm{NH} 2+$ & 1266.4 & $\mathrm{H} 2 \mathrm{O}+$ & 977.9 & SIH2+ & 1155.2 \\
\hline $\mathrm{PH} 2+$ & 1090.0 & $\mathrm{H} 2 \mathrm{~S}+$ & 991.0 & $\mathrm{H} 2 \mathrm{CL}+$ & 867.0 & $\mathrm{C} 2 \mathrm{H}+$ & 1689.0 & $\mathrm{HCN}+$ & 1448.0 \\
\hline $\mathrm{HCO}+$ & 825.6 & $\mathrm{HOC}+$ & 963.0 & HCSI+ & $\ldots \ldots$ & $\mathrm{HCP}+$ & 1208.0 & $\mathrm{HCS}+$ & 1018.0 \\
\hline $\mathrm{N} 2 \mathrm{H}+$ & 1035.5 & $\mathrm{HNO}+$ & 1074.4 & HNSI+ & $\ldots \ldots$ & $\mathrm{HPN}+$ & $\ldots \ldots$ & HNS+ & $\ldots \ldots$ \\
\hline $\mathrm{O} 2 \mathrm{H}+$ & 1108.5 & $\mathrm{SIOH}+$ & $\ldots \ldots$ & $\mathrm{HPO}+$ & $\ldots \ldots$ & $\mathrm{HSO}+$ & $\ldots \ldots$ & HSIS+ & $\ldots \ldots$ \\
\hline $\mathrm{S} 2 \mathrm{H}+$ & $\ldots \ldots$ & $\mathrm{C} 3+$ & 2004.0 & $\mathrm{CCN}+$ & 1715.0 & $\mathrm{CNC}+$ & 1620.0 & $\mathrm{C} 2 \mathrm{O}+$ & $\ldots \ldots$ \\
\hline SIC2+ & 1594.0 & $\mathrm{CCP}+$ & $\ldots \ldots$ & $\mathrm{C} 2 \mathrm{~S}+$ & $\ldots \ldots$ & $\mathrm{NCO}+$ & 1289.0 & SINC+ & $\ldots \ldots$ \\
\hline $\mathrm{CO} 2+$ & 935.7 & $\mathrm{OCS}+$ & 936.0 & NO2+ & 977.0 & $\mathrm{SO} 2+$ & 894.0 & CH3+ & 1098.0 \\
\hline NH3+ & 941.0 & $\mathrm{H} 3 \mathrm{O}+$ & 597.0 & SIH3+ & 992.0 & PH3+ & 966.0 & H3S+ & 797.0 \\
\hline $\mathrm{C} 2 \mathrm{H} 2+$ & 1328.5 & $\mathrm{HCNH}+$ & 947.0 & $\mathrm{H} 2 \mathrm{NC}+$ & 1109.0 & $\mathrm{H} 2 \mathrm{CO}+$ & 944.5 & SICH2+ & $\ldots \ldots$ \\
\hline $\mathrm{PCH} 2+$ & $\ldots \ldots$ & $\mathrm{H} 2 \mathrm{CS}+$ & 1006.0 & $\mathrm{H} 2 \mathrm{CCL}+$ & 962.1 & $\mathrm{H} 2 \mathrm{NO}+$ & 939.7 & $\mathrm{SINH} 2+$ & 889.9 \\
\hline PNH2+ & $\ldots \ldots$ & $\mathrm{H} 2 \mathrm{SIO}+$ & $\ldots \ldots$ & $\mathrm{H} 2 \mathrm{PO}+$ & $\ldots \ldots$ & $\mathrm{H} 2 \mathrm{~S} 2+$ & 913.0 & $\mathrm{C} 3 \mathrm{H}+$ & 1593.0 \\
\hline $\mathrm{CCNH}+$ & 1531.0 & $\mathrm{HC} 2 \mathrm{O}+$ & 1096.0 & $\mathrm{C} 2 \mathrm{HO}+$ & $\ldots \ldots$ & SIC2H+ & $\ldots \ldots$ & $\mathrm{PC} 2 \mathrm{H}+$ & $\ldots \ldots$ \\
\hline $\mathrm{HC} 2 \mathrm{~S}+$ & $\ldots \ldots$ & $\mathrm{HNCO}+$ & 1015.0 & SINCH+ & $\ldots \ldots$ & $\mathrm{HCO} 2+$ & 589.0 & HOCS+ & 757.0 \\
\hline HSIO2+ & $\ldots \ldots$ & HSO2+ & 597.0 & $\mathrm{C} 4+$ & 2187.0 & $\mathrm{C} 3 \mathrm{~N}+$ & $\ldots \ldots$ & $\mathrm{C} 3 \mathrm{O}+$ & $\ldots \ldots$ \\
\hline SIC3+ & $\ldots \ldots$ & C3S+ & $\ldots \ldots$ & $\mathrm{C} 2 \mathrm{~N} 2+$ & 1594.8 & $\mathrm{CH} 4+$ & 1140.0 & $\mathrm{NH} 4+$ & 630.0 \\
\hline SIH4+ & 1170.0 & $\mathrm{C} 2 \mathrm{H} 3+$ & 1120.9 & $\mathrm{H} 3 \mathrm{CO}+$ & 703.0 & SICH3+ & 977.0 & PCH3+ & $\ldots \ldots$ \\
\hline H3CS+ & 901.0 & PNH3+ & $\ldots \ldots$ & H3SIO+ & $\ldots \ldots$ & H3S2+ & $\ldots \ldots$ & C3H2+ & 1381.0 \\
\hline $\mathrm{CH} 2 \mathrm{CN}+$ & 1214.0 & $\mathrm{CH} 2 \mathrm{CO}+$ & 882.7 & $\mathrm{SIC} 2 \mathrm{H} 2+$ & $\ldots \ldots$ & $\mathrm{PC} 2 \mathrm{H} 2+$ & $\ldots \ldots$ & $\mathrm{C} 4 \mathrm{H}+$ & 1805.0 \\
\hline
\end{tabular}


Table 2. continued

\begin{tabular}{|c|c|c|c|c|c|c|c|c|c|}
\hline $\mathrm{HC} 3 \mathrm{~N}+$ & 1474.0 & $\mathrm{HC} 3 \mathrm{O}+$ & 971.0 & SIC3H+ & $\cdots$ & $\mathrm{PC} 3 \mathrm{H}+$ & $\cdots$ & HC3S+ & \\
\hline C5+ & 2162.0 & $\mathrm{C} 4 \mathrm{~N}+$ & $\ldots$ & SIC4+ & ....... & $\mathrm{C} 4 \mathrm{P}+$ & ...... & $\mathrm{C} 4 \mathrm{~S}+$ & $\ldots \ldots$ \\
\hline $\mathrm{CH} 5+$ & 905.0 & SIH5+ & 917.0 & $\mathrm{C} 2 \mathrm{H} 4+$ & 1074.0 & $\mathrm{CH} 4 \mathrm{~N}+$ & 745.0 & CH2NH2+ & $\ldots \ldots$ \\
\hline $\mathrm{CH} 3 \mathrm{OH}+$ & 856.2 & SICH4+ & 1015.0 & $\mathrm{PCH} 4+$ & $\ldots$. & C3H3+ & 1075.0 & $\mathrm{H} 2 \mathrm{C} 3 \mathrm{H}+$ & $\ldots \ldots$ \\
\hline $\mathrm{CH} 3 \mathrm{CN}+$ & 1258.0 & $\mathrm{CH} 3 \mathrm{CO}+$ & 653.0 & SIC2H3+ & & $\mathrm{PC} 2 \mathrm{H} 3+$ & $\ldots$. & $\mathrm{CHOOH} 2+$ & 403.0 \\
\hline $\mathrm{C} 4 \mathrm{H} 2+$ & 1422.0 & $\mathrm{H} 2 \mathrm{C} 3 \mathrm{~N}+$ & 1127.5 & $\mathrm{C} 3 \mathrm{H} 2 \mathrm{O}+$ & 1157.0 & SIC3H2+ & ...... & $\mathrm{C} 5 \mathrm{H}+$ & $\ldots \ldots$ \\
\hline $\mathrm{HC} 4 \mathrm{~N}+$ & $\ldots \ldots$ & $\mathrm{SIC} 4 \mathrm{H}+$ & $\ldots \ldots$ & $\mathrm{PC} 4 \mathrm{H}+$ & $\ldots \ldots$ & $\mathrm{HC} 4 \mathrm{~S}+$ & $\ldots \ldots$ & $\mathrm{C} 6+$ & $\ldots \ldots$ \\
\hline $\mathrm{C} 5 \mathrm{~N}+$ & $\ldots \ldots$ & $\mathrm{C} 2 \mathrm{H} 5+$ & 914.0 & CH3OH2+ & 567.0 & C3H4+ & 1194.5 & $\mathrm{H} 4 \mathrm{C} 2 \mathrm{~N}+$ & 817.0 \\
\hline $\mathrm{CH} 3 \mathrm{CHO}+$ & 831.9 & $\mathrm{PC} 2 \mathrm{H} 4+$ & $\ldots \ldots$ & C4H3+ & 1217.0 & $\mathrm{H} 3 \mathrm{C} 3 \mathrm{O}+$ & 751.0 & C5H2+ & $\ldots \ldots$ \\
\hline $\mathrm{H} 2 \mathrm{C} 4 \mathrm{~N}+$ & $\ldots \ldots$ & $\mathrm{PC} 4 \mathrm{H} 2+$ & $\ldots$. & $\mathrm{C} 6 \mathrm{H}+$ & 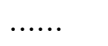 & $\mathrm{HC} 5 \mathrm{~N}+$ & $\ldots$ & $\mathrm{C} 7+$ & 2299.0 \\
\hline $\mathrm{C} 2 \mathrm{H} 6+$ & 1043.0 & $\mathrm{C} 3 \mathrm{H} 5+$ & 969.0 & $\mathrm{C} 2 \mathrm{H} 5 \mathrm{O}+$ & 583. & $\mathrm{H} 5 \mathrm{C} 2 \mathrm{O}+$ & $\ldots \ldots$ & $\mathrm{H} 4 \mathrm{C} 3 \mathrm{~N}+$ & 817.0 \\
\hline $\mathrm{COOCH} 4+$ & 688.0 & C5H3+ & $\ldots \ldots$ & $\mathrm{H} 3 \mathrm{C} 4 \mathrm{~N}+$ & $\ldots \ldots$ & C6H2+ & 1569.0 & $\mathrm{H} 2 \mathrm{C} 5 \mathrm{~N}+$ & $\ldots \ldots$ \\
\hline $\mathrm{C} 7 \mathrm{H}+$ & $\ldots \ldots$ & $\mathrm{C} 8+$ & $\ldots \ldots$ & $\mathrm{C} 7 \mathrm{~N}+$ & $\ldots \ldots$ & $\mathrm{C} 2 \mathrm{H} 7+$ & 856.4 & $\mathrm{C} 2 \mathrm{H} 5 \mathrm{OH}+$ & 793.1 \\
\hline $\mathrm{C} 2 \mathrm{H} 6 \mathrm{O}+$ & 801.0 & $\mathrm{C} 4 \mathrm{H} 5+$ & 1076.0 & $\mathrm{H} 5 \mathrm{C} 2 \mathrm{O} 2+$ & 386.0 & C5H4+ & 1332.0 & $\mathrm{H} 4 \mathrm{C} 4 \mathrm{~N}+$ & $\ldots \ldots$ \\
\hline $\mathrm{C} 6 \mathrm{H} 3+$ & $\ldots \ldots$ & $\mathrm{H} 3 \mathrm{C} 5 \mathrm{~N}+$ & $\ldots$. & $\mathrm{C} 7 \mathrm{H} 2+$ & $\ldots$ & $\mathrm{C} 8 \mathrm{H}+$ & $\ldots$ & $\mathrm{HC} 7 \mathrm{~N}+$ & $\cdots$ \\
\hline $\mathrm{C} 9+$ & 2451.0 & $\mathrm{C} 2 \mathrm{H} 6 \mathrm{OH}+$ & 542.0 & $\mathrm{C} 2 \mathrm{H} 7 \mathrm{O}+$ & 507. & $\mathrm{C} 2 \mathrm{H} 6 \mathrm{CO}+$ & 719.7 & C5H5+ & 1132.0 \\
\hline $\mathrm{C} 6 \mathrm{H} 4+$ & 1400.0 & C7H3+ & $\ldots \ldots$ & $\mathrm{C} 8 \mathrm{H} 2+$ & 1741.0 & $\mathrm{H} 2 \mathrm{C} 7 \mathrm{~N}+$ & $\ldots \ldots$ & $\mathrm{C} 9 \mathrm{H}+$ & $\ldots \ldots$ \\
\hline $\mathrm{C} 10+$ & $\ldots \ldots$ & $\mathrm{C} 9 \mathrm{~N}+$ & $\ldots \ldots$ & $\mathrm{C} 3 \mathrm{H} 6 \mathrm{OH}+$ & 490.0 & $\mathrm{C} 6 \mathrm{H} 5+$ & 1141.3 & C7H4+ & $\ldots \ldots$ \\
\hline $\mathrm{H} 4 \mathrm{C} 6 \mathrm{~N}+$ & $\ldots \ldots$ & C8H3+ & $\ldots \ldots$ & $\mathrm{H} 3 \mathrm{C} 7 \mathrm{~N}+$ & $\ldots \ldots$ & $\mathrm{C} 9 \mathrm{H} 2+$ & $\ldots \ldots$ & $\mathrm{HC} 9 \mathrm{~N}+$ & $\ldots \ldots$ \\
\hline C7H5+ & $\cdots$ & $\mathrm{C} 8 \mathrm{H} 4+$ & $\ldots \ldots$ & C9H3+ & ...... & $\mathrm{H} 2 \mathrm{C} 9 \mathrm{~N}+$ & $\ldots \ldots$ & $\mathrm{C} 8 \mathrm{H} 5+$ & $\cdots \cdots$ \\
\hline $\mathrm{C} 9 \mathrm{H} 4+$ & 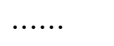 & $\mathrm{H} 4 \mathrm{C} 8 \mathrm{~N}+$ & $\ldots \ldots$ & $\mathrm{H} 3 \mathrm{C} 9 \mathrm{~N}+$ & $\ldots$. & C9H5+ & $\ldots \ldots$ & ELECTR & $\ldots \ldots$ \\
\hline
\end{tabular}

Notes: These data were compiled from the JANAF tables by H.-H. Lee (Ohio State University), with the exception of the heats of formation for the carbon chains $\mathrm{C}_{n}, n=2-7$, which come from Gingerich et al. (1994), and for the carbenes, $\mathrm{H}_{2} \mathrm{C}_{n}$, which come from Bettens et al. (1995).

- Reactions 395 - 3197. Ion-neutral reactions, including reactions of positive and negative ions.

- Reactions 3198 - 3634. Electron reactions, including radiative electron attachment of $\mathrm{H}, \mathrm{C}, \mathrm{O}$ and $\mathrm{S}$, as well as radiative and dissociative recombination of positive ions.

- Reactions 3635 - 3645. Ionisation by cosmic-ray protons.

- Reactions 3646 - 3795. Photoreactions driven by the general interstellar ultraviolet radiation field.

- Reactions 3796 - 3864. Cosmic-ray-induced photoreactions.

\subsection{The entry format}

Each entry in Table 4 has the following form:

$$
\text { I, R1, R2, P1, P2, P3, P4, } \alpha, \beta, \gamma \text {, Note }
$$

where $\mathrm{I}$ is the reaction number, $\mathrm{R} 1$ and $\mathrm{R} 2$ are reactants - R2 can be a cosmic-ray proton (CRP), an interstellar photon (PHOTON), or a cosmic-ray-induced photon (CR$\mathrm{PHOT}$ ) - and $\mathrm{P} 1$ to $\mathrm{P} 4$ are reaction products, with the entry format given by:

1X, A4, 1X, 4(1A7, 1X), A3, 1X, A3, 1PE8.2, 1X, 0PF5.2, 1X, F8.1, A9
For each reaction, $\alpha, \beta$ and $\gamma$ are used to calculate the rate coefficient by:

$k=\alpha(T / 300)^{\beta} \exp (-\gamma / T) \quad \mathrm{cm}^{3} \mathrm{~s}^{-1}$

for two-body reactions, where $T$ is the gas temperature,

$k=\alpha \quad \mathrm{s}^{-1}$

for direct cosmic-ray ionisation $(\mathrm{R} 2=\mathrm{CRP})$,

$k=\alpha \exp \left(-\gamma A_{V}\right) \quad \mathrm{s}^{-1}$

for interstellar photoreactions ( $\mathrm{R} 2=$ PHOTON), where $\alpha$ represents the rate in the unshielded interstellar ultraviolet radiation field, $A_{V}$ is the extinction at visible wavelengths caused by interstellar dust, $\gamma$ is the parameter used to take into account the increased extinction of dust at ultraviolet wavelengths, and

$k=\alpha \gamma /(1-\omega) \quad \mathrm{s}^{-1}$

for cosmic-ray-induced photoreactions ( $\mathrm{R} 2=\mathrm{CRPHOT})$, where $\omega$ is the grain albedo in the far ultraviolet, typically 0.6 at $150 \mathrm{~nm}, \alpha$ the cosmic-ray ionisation rate and $\gamma$ is the probability per cosmic-ray ionisation that the appropriate photoreaction takes place.

Grain surface reactions are not included in this database since there is, as yet, little consensus on the magnitude of the appropriate rate coefficients nor, indeed, on 
Table 3. Permanent electric dipole moments in Debye of the neutral molecules

\begin{tabular}{|c|c|c|c|c|c|}
\hline Species & $\mu_{D}$ & Species & $\mu_{D}$ & Species & $\mu_{D}$ \\
\hline $\mathrm{H} 2$ & 0 & $\mathrm{CH}$ & 1.46 & $\mathrm{NH}$ & 1.3 \\
\hline $\mathrm{OH}$ & 1.66 & $\mathrm{SiH}$ & 0.12 & $\mathrm{PH}$ & 0.64 \\
\hline HS & 0.76 & $\mathrm{HCl}$ & 1.08 & $\mathrm{C} 2$ & 0 \\
\hline $\mathrm{CN}$ & 1.45 & $\mathrm{CO}$ & 0.112 & $\mathrm{SiC}$ & 1.7 \\
\hline $\mathrm{CP}$ & 0.86 & CS & 1.96 & $\mathrm{CCl}$ & $<0.65$ \\
\hline $\mathrm{N} 2$ & 0 & $\mathrm{NO}$ & 0.153 & $\mathrm{SiN}$ & $\sim 2.3$ \\
\hline $\mathrm{PN}$ & 2.75 & NS & 1.81 & $\mathrm{O} 2$ & 0 \\
\hline $\mathrm{SiO}$ & 3.1 & $\mathrm{PO}$ & 1.88 & $\mathrm{SO}$ & 1.55 \\
\hline $\mathrm{ClO}$ & 1.24 & $\mathrm{SiS}$ & 1.73 & $\mathrm{~S} 2$ & 0 \\
\hline $\mathrm{CH} 2$ & 0.57 & NH2 & 1.83 & $\mathrm{H} 2 \mathrm{O}$ & 1.85 \\
\hline $\mathrm{SiH} 2$ & 0.18 & PH2 & $\ldots$ & $\mathrm{H} 2 \mathrm{~S}$ & 0.97 \\
\hline $\mathrm{C} 2 \mathrm{H}$ & 0.8 & $\mathrm{HCN}$ & 2.98 & $\mathrm{HNC}$ & 2.7 \\
\hline $\mathrm{HCO}$ & $\sim 1.0$ & HCSi & $\ldots$. & $\mathrm{HCP}$ & 0.3 \\
\hline HCS & $\ldots$ & HNO & 1.67 & HNSi & 0.16 \\
\hline $\mathrm{O} 2 \mathrm{H}$ & 2.09 & HPO & 2.33 & HS2 & $\ldots$. \\
\hline C3 & 0 & $\mathrm{CCN}$ & 0.6 & $\mathrm{CCO}$ & 1.3 \\
\hline $\mathrm{SiC} 2$ & 2.39 & $\mathrm{CCP}$ & $\ldots$ & $\mathrm{C} 2 \mathrm{~S}$ & 2.8 \\
\hline $\mathrm{OCN}$ & 0.64 & SiNC & 2.03 & $\mathrm{CO} 2$ & 0 \\
\hline OCS & 0.71 & $\mathrm{~N} 2 \mathrm{O}$ & 0.16 & NO2 & 0.32 \\
\hline $\mathrm{SiO} 2$ & $\sim 0.5$ & SO2 & 1.63 & CH3 & 0 \\
\hline NH3 & 1.47 & SiH3 & 0 & $\mathrm{C} 2 \mathrm{H} 2$ & 0 \\
\hline $\mathrm{H} 2 \mathrm{O} 2$ & 1.57 & $\mathrm{H} 2 \mathrm{~S} 2$ & 1.2 & $\mathrm{H} 2 \mathrm{CN}$ & 2.54 \\
\hline $\mathrm{H} 2 \mathrm{CO}$ & 2.33 & $\mathrm{SiCH} 2$ & $\ldots$. & $\mathrm{H} 2 \mathrm{CS}$ & 1.65 \\
\hline $\mathrm{H} 2 \mathrm{SiO}$ & $\ldots$ & l-C3H & 3.1 & $\mathrm{SiC} 2 \mathrm{H}$ & 1.4 \\
\hline HCCP & 0 & $\mathrm{C} 4$ & 0 & $\mathrm{C} 3 \mathrm{~N}$ & 2.2 \\
\hline $\mathrm{C} 3 \mathrm{O}$ & 2.39 & $\mathrm{SiC} 3$ & $\ldots$ & $\mathrm{C} 3 \mathrm{P}$ & $\ldots$. \\
\hline C3S & 3.7 & $\mathrm{CH} 4$ & 0 & $\mathrm{SiH} 4$ & 0 \\
\hline $\mathrm{C} 2 \mathrm{H} 3$ & $\sim 1.5$ & $\mathrm{CH} 2 \mathrm{NH}$ & 2.02 & $\mathrm{SiCH} 3$ & $\ldots$ \\
\hline $\mathrm{CH} 2 \mathrm{PH}$ & $\ldots$ & $\mathrm{c}-\mathrm{C} 3 \mathrm{H} 2$ & 3.4 & $\mathrm{CH} 2 \mathrm{CN}$ & 1.62 \\
\hline $\mathrm{CH} 2 \mathrm{CO}$ & 1.42 & $\mathrm{SiC} 2 \mathrm{H} 2$ & 2.5 & $\mathrm{CHOOH}$ & 1.41 \\
\hline $\mathrm{C} 4 \mathrm{H}$ & 0.9 & $\mathrm{HC} 3 \mathrm{~N}$ & 3.6 & $\mathrm{SiC} 3 \mathrm{H}$ & $\ldots$ \\
\hline C5 & 0 & $\mathrm{SiC} 4$ & 6.3 & $\mathrm{C} 4 \mathrm{P}$ & $\ldots$ \\
\hline $\mathrm{C} 4 \mathrm{~S}$ & $\sim 3.0$ & $\mathrm{C} 2 \mathrm{H} 4$ & 0 & СH3OH & 1.7 \\
\hline $\mathrm{C} 3 \mathrm{H} 3$ & 4.0 & $\mathrm{CH} 3 \mathrm{CN}$ & 3.92 & $\mathrm{H} 2 \mathrm{CCCC}$ & $4.5 \mathrm{D}$ \\
\hline $\mathrm{C} 5 \mathrm{H}$ & 4.3 & C6 & 0 & $\mathrm{C} 5 \mathrm{~N}$ & $\sim 2.7$ \\
\hline $\mathrm{C} 2 \mathrm{H} 5$ & $\ldots$ & $\mathrm{C} 3 \mathrm{H} 4[\mathrm{CH} 3 \mathrm{CCH}]$ & 0.78 & $\mathrm{CH} 3 \mathrm{CHO}$ & 2.69 \\
\hline $\mathrm{H} 3 \mathrm{C} 3 \mathrm{~N}$ [CH2CHCN] & 3.89 & $\mathrm{C} 5 \mathrm{H} 2$ & 2.5 & $\mathrm{C} 6 \mathrm{H}$ & 5.0 \\
\hline $\mathrm{HC} 5 \mathrm{~N}$ & 4.33 & $\mathrm{C} 7$ & 0 & $\mathrm{C} 2 \mathrm{H} 6$ & 0 \\
\hline HCOOCH3 & 1.77 & H3C4N [CH3C3N] & 4.91 & $\mathrm{C} 6 \mathrm{H} 2$ & 0 \\
\hline $\mathrm{C} 7 \mathrm{H}$ & 4.5 & $\mathrm{C} 8$ & 0 & $\mathrm{C} 7 \mathrm{~N}$ & 3.0 \\
\hline CH3OCH3 & 1.3 & $\mathrm{C} 2 \mathrm{H} 5 \mathrm{OH}$ & 1.44 & $\mathrm{C} 5 \mathrm{H} 4[\mathrm{CH} 3 \mathrm{C} 4 \mathrm{H}]$ & 1.21 \\
\hline $\mathrm{C} 7 \mathrm{H} 2$ & 2.5 & $\mathrm{C} 8 \mathrm{H}$ & 5.0 & $\mathrm{HC} 7 \mathrm{~N}$ & 4.62 \\
\hline C9 & 0 & $\mathrm{C} 2 \mathrm{H} 6 \mathrm{CO}$ & 2.8 & $\mathrm{H} 3 \mathrm{C} 6 \mathrm{~N}$ [CH3C5N] & 5.75 \\
\hline $\mathrm{C} 8 \mathrm{H} 2$ & 0 & $\mathrm{C} 9 \mathrm{H}$ & 4.7 & $\mathrm{C} 9 \mathrm{~N}$ & 3.3 \\
\hline $\mathrm{C} 7 \mathrm{H} 4[\mathrm{CH} 3 \mathrm{C} 6 \mathrm{H}]$ & 1.5 & $\mathrm{C} 9 \mathrm{H} 2$ & 2.5 & $\mathrm{HC} 9 \mathrm{~N}$ & 4.84 \\
\hline $\mathrm{H} 3 \mathrm{C} 8 \mathrm{~N}$ [CH3C7N] & 5.47 & & & & \\
\hline
\end{tabular}

Notes: c-C3H $=2.4 \mathrm{D} ; \mathrm{H} 2 \mathrm{CCC}=4.1 \mathrm{D} ; \mathrm{HCCCCH}=0 \mathrm{D} ; \mathrm{H} 2 \mathrm{C} 3 \mathrm{H}($ propargyl $)=0.14 \mathrm{D}$; C3S from Suernam \& Lovas (1994); CH3C3N and CH3C5N from Botschwina et al. (1994); H2CCCC from Oswald \& Botschwina (1995); H2C3H from Botschwina et al. (1995); C5O from Botschwina, Flugge \& Sebald 1995. 
the mode of reaction. One important omission is the formation of $\mathrm{H}_{2}$ which is known to take place on the surfaces of interstellar grains and for which a reasonable estimate of the rate can be deduced both from theory (Hollenbach \& Salpeter 1972) and observation (Jura 1975a,b).

'Note' is a nine-column entry which gives information on the type and source of the data and has the form:-

- Column 1: An ' $\mathrm{M}$ ' here means that the rate coefficient has been measured in the laboratory or, in the case of radiative association, has been deduced with the aid of an experiment on the analogous three-body association. For ion-neutral reactions, the rate coefficients are generally independent of temperature. An important exception are those reactions in which the neutral molecule has a large, say greater than 1 Debye, permanent electric dipole moment. In such cases, the rate coefficients generally increase at low temperatures (Adams et al. 1985). Table 3 gives electric dipole moments, where available, for the neutral species in the database.

Neutral-neutral reactions are usually studied experimentally at room temperature and above and therefore application of laboratory-determined rate coefficients to the low temperature environments of interstellar clouds is fraught with uncertainty. For example, it is possible that several reactions listed in the ratefile as not possessing an activation energy do, in fact, have small barriers $(<100 \mathrm{~K})$ which are not evident in measurements done at room temperature and above.

- Columns 2,3: A two-letter symbol for the type of reaction. The symbols used are: AD, associative detachment; CD, collisional dissociation; $\mathrm{CH}$, chemiionisation; CI, carbon insertion, involving a reaction between a carbon atom and a hydrocarbon ion; $\mathrm{CP}$, cosmic-ray-induced photoreaction; CO, positive ion-neutral reaction in which $\mathrm{H}$ and/or $\mathrm{H}_{2}$ are the only neutral products; CR, cosmic-ray ionisation; CT, charge transfer; DR, dissociative recombination with electrons; HA, hydrogen abstraction; MN, mutual neutralisation; NA, neutral radiative association; NE, neutral exchange; NI, negative ion-neutral; PD, photodissociation; PI, photoionisation; PM, photodetachment of electron; PN, positive ion-neutral; PT, proton transfer; RA, radiative association between a positive ion and a neutral molecule; RM, radiative electron (minus ion) attachment; $\mathrm{RR}$, radiative recombination with electrons.

- Column 4: A label is used to denote the relevance of a reaction. In many instances the user will be interested in using only a subset of the reaction file, and may want, for ease of computation and analysis, to neglect unimportant reactions. Certain types of reaction may be excluded from a particular model. For example, reactions with large activation energy barriers, which are important in shocked gas, and photoreactions can be neglected in models of cold, dark clouds. In addition, however, there are reactions whose neglect will not seriously compromise the results of most models. These are labelled with an ' $\mathrm{E}$ ' in this column. This category is most used for ions, such as $\mathrm{NH}^{+}$and $\mathrm{H}_{2} \mathrm{O}^{+}$, which have rapid reactions with $\mathrm{H}_{2}$. The low abundance of all other species $\mathrm{X}$ relative to $\mathrm{H}_{2}$ in many astronomical regions, means that all ion-X reactions can be excluded. This criterion is only useful if $\mathrm{H}_{2}$ is the dominant form of hydrogen. If a reaction should be included in any comprehensive model it is labelled with an 'A'.

- Column 5: A digit is used to represent the accuracy of the data. We have used such labelling mainly for the ion-neutral and photoreactions, although sometimes the accuracy of the formula given may be restricted to a particular range of temperature. The following scheme has been used:

-1 . Error $<25 \%$

- 2. Error $<50 \%$

- 3. Error to within a factor of 2

- 4. Error within an order of magnitude

-5 . Highly uncertain

We have not attempted to give the accuracy of the unmeasured reactions. The ion-neutral rate coefficients should be accurate to a factor of two, but it is possible that some of the reactions included here have different products or are unreactive.

- Columns 6-9: A label to the source of the data. Labels of the form ' 8010 ' refer to the labelling scheme of Anicich \& Huntress (1986) and Anicich (1993). Details of the letter codes, such as RJ91, are given in the footnote to Table 4. The label 'NIST', used for many of the neutral-neutral reactions, refers to the National Institute of Standards and Technology Chemical Kinetics Database - Ver. 6.0 (Mallard et al. 1994).

\subsection{Alterations present in this release}

Major changes to the original database include:-

- Recently measured reactions of neutral carbon with hydrocarbons (Clary et al. 1994), and low-temperature rate coefficients of CN with neutral molecules (Sims et al. 1992, 1993a,b).

- A more detailed chemistry of phosphorus (Millar 1991; Charnley \& Millar 1994) with experimental data on ion-neutral reactions taken mainly from Adams et al. (1990). Among new phosphorus-bearing molecules included are the organo-phosphorus species HCP, CCP, $\mathrm{HCCP}, \mathrm{C}_{3} \mathrm{P}, \mathrm{C}_{4} \mathrm{P}$ and $\mathrm{CH}_{2} \mathrm{PH}$.

- The chemistry of complex hydrocarbons with neutral molecules containing up to nine carbon atoms, including the cyanopolyynes $\mathrm{HC}_{7} \mathrm{~N}$ and $\mathrm{HC}_{9} \mathrm{~N}$. These reactions are taken from Herbst \& Leung (1989).

- Separate reactions have been included for the linear and cyclic isomers of $\mathrm{C}_{3} \mathrm{H}_{2} \cdot \mathrm{C}_{3} \mathrm{H}_{2}$ and $\mathrm{C}_{3} \mathrm{H}_{3}^{+}$denote the cyclic species and its proton and $\mathrm{H}_{2} \mathrm{C}_{3}$ denotes the 
linear cumulene, $\mathrm{H}_{2} \mathrm{CCC}$, and $\mathrm{H}_{2} \mathrm{C}_{3} \mathrm{H}^{+}$its protonated form.

- The photoreactions caused by the ultraviolet photons induced by the cosmic-ray ionisation of $\mathrm{H}_{2}$, the socalled Prasad-Tarafdar mechanism (Prasad \& Tarafdar 1983), with rates taken from Gredel et al. $(1987,1989)$.

- Specific reactions for the synthesis of some recently detected molecules, including CCO (Ohishi et al. 1991) and $\mathrm{CH}_{2} \mathrm{CN}$ (Herbst \& Leung 1990), and a more detailed chemistry for vinyl cyanide, $\mathrm{CH}_{2} \mathrm{CHCN}$, based on the laboratory work of Petrie et al. (1992).

- Photorates taken from the compilation of Roberge et al. (1991) and scaled to the Draine (1978) UV radiation field.

- The inclusion of chemistry appropriate for hot molecular cores, mostly taken from the work of Charnley et al. (1992).

It should be noted that while the reaction set is closed, i.e. all species have at least one formation and destruction reaction, several of the hot core species are probably formed by grain surface reactions since they do not have efficient gas-phase routes to their syntheses. As a result, the species $\mathrm{C}_{2} \mathrm{H}_{5}, \mathrm{C}_{2} \mathrm{H}_{6}$, and $\mathrm{SiH}_{4}$ and their ions should not be included in a purely gas-phase scheme, since they have no gas-phase formation routes. In hot molecular core models, they are assumed to be present with some initial abundance determined by grain surface reactions.

\subsection{Particular reactions}

\subsubsection{Neutral-neutral reactions (Nos. 1 - 394)}

The original rate file (Millar et al. 1991b) was ordered slightly differently in that the first reaction block listed those reactions possessing activation energies. The rationale was that in a particular low-temperature application, this block of reactions could be edited out. However, it turns out that a number of reactions previously thought to possess activation energies do not and vice versa. In addition, the speed of modern computers means that it is not much more costly to compute a chemical model with all reactions in the rate file. We have therefore gathered all neutral-neutral reactions in the first block.

Additional reactions to this section include those associated with phosphorus chemistry, e.g. $\mathrm{O}+\mathrm{C}_{n} \mathrm{P}(n=$ $1-4)$, taken from Millar (1991) and large carbon-chain chemistry, in particular reactions involving atomic oxygen (Herbst \& Leung 1989) and atomic carbon (Haider \& Husain 1993a,b; Clary et al. 1994), the chemistry of $\mathrm{H}_{2} \mathrm{CN}$ (Marston et al. 1989), and low-temperature reactions of CN with several neutral molecules (Sims et al. 1992, 1993a,b). Several of the reactions involve nonconservation of spin and may have rate coefficients smaller than tabulated or possess activation energy barriers. In some systems, the presence of low-lying electronic states may alter the products and rate coefficients.
Much effort has gone in to evaluating the neutralneutral rate coefficients and in trying to include as many experimental determinations as possible. We have therefore searched the National Institute of Standards and Technology (NIST) Chemical Kinetics Database - Version 6 (Mallard et al. 1994) and included what we believe to be the most appropriate form of the rate coefficient. It is important to remember that neutral-neutral reactions are usually studied at room temperature and above so that application of laboratory-determined rate coefficients to low-temperature interstellar cloud models is often insecure. For example, it is possible that several reactions listed as having no activation energy do, in fact, have small barriers $(<100 \mathrm{~K})$ which are not evident in measurements performed at room temperature. In addition, some reactions in the NIST Database are best characterised by a negative activation energy barrier since their rate coefficients increase with decreasing temperature. In order to prevent a serious over-estimate of these rate coefficients at $10 \mathrm{~K}$, we have generally preferred to adopt an alternative, although still accurate, form for the rate coefficients, for example, one involving a power-law dependence on temperature. Normally, the NIST Database contains such alternative formulations. Roughly one half of the neutralneutral reactions have been studied in the laboratory.

Finally, it is important to note that rate coefficients for the collisional dissociation (CD) reactions are dependent on both density and temperature and reference to the appropriate values to use in particular circumstances should be made to the original papers (Roberge \& Dalgarno 1982; Dove \& Mandy 1986).

\subsubsection{Ion-neutral reactions (Nos. 395 - 3197)}

This block includes the reactions of some negative ions as well as the more usual positive ion-neutral reactions. Around one-third of the 2800 reactions have experimentally determined rate coefficients, with several tens of rate coefficients studied at temperatures less than $100 \mathrm{~K}$. The accuracy of the remaining rate coefficients is fairly high since theoretical methods for determining these depend chiefly on long-range forces and are very reliable for exothermic systems. At temperatures less than about $50 \mathrm{~K}$, the presence of a neutral having a large electric dipole increases the rate coefficient (Adams et al. 1985). As mentioned above, there are various approximations which can be used to derive the low-temperature rate coefficients for such systems.

There are some limitations on the data presented here. For example, the radiative association reactions are labelled ' $\mathrm{M}$ ', for measured, although in fact it is their threebody analogues which have been studied experimentally. The association rate coefficients are derived theoretically from these rates and are parameterised in a form which is valid only for the $10-50 \mathrm{~K}$ temperature range in general. At higher temperatures, different values and different 
temperature dependencies can apply. Furthermore, some important reactions, in particular the $\mathrm{N}^{+}-\mathrm{H}_{2}$ and $\mathrm{C}_{2} \mathrm{H}_{2}-$ $\mathrm{H}_{2}$ reactions, have rate coefficients not easily approximated by the format in Table 4 . Such reactions are discussed in detail by Millar et al. (1991b).

\subsubsection{Reactions involving electrons (Nos. 3198 - 3634)}

This block includes electron attachment (of $\mathrm{H}, \mathrm{C}, \mathrm{O}$ and $\mathrm{S}$ ) as well as radiative and dissociative recombination of positive ions. An increasing number of dissociative recombination reactions have been studied in the laboratory (Herd et al. 1990; Amano 1990; Adams et al. 1991; Mitchell 1990; Canosa et al. 1991) and reviews have been given by Adams (1992) and several in a conference proceedings (Rowe et al. 1993). Branching ratios still remain an area of uncertainty in most cases. The dissociative recombination rate coefficient of $\mathrm{H}_{3}^{+}$remains a matter of some debate (Amano 1990; Canosa et al. 1991; Smith \& Spanel 1993; Sundstrom et al. 1994) although there has been a significant narrowing of the differences between rate coefficients measured in several laboratories. In general, calculated molecular abundances are not very sensitive to the total dissociative recombination rate coefficient but are sensitive to the adopted branching ratios.

\subsubsection{Photoprocesses (Nos. 3646 - 3795)}

We have added a number of photoreactions taken from the compilation of Roberge et al. (1991), scaled to the interstellar radiation field determined by Draine (1978). Photorates should be used with care for a number of reasons. Some species, most importantly $\mathrm{H}_{2}$ and $\mathrm{CO}$, dissociate via absorption of line radiation and thus self-shield. This is not included in the rate file and approaches such as those discussed by van Dishoeck \& Black (1988), Lee et al. (1996) and Warin et al. (1996) need to be incorporated into chemical models. In addition, the intensity of ultraviolet radiation at any point in a cloud is determined by the properties of the small interstellar dust grains which control the transfer of radiation. Both the pre-exponential $(\alpha)$ and the exponential $(\gamma)$ factors can be different for different grain populations (see Roberge et al. 1991). In some cases, a bi-exponential formula is to be preferred (see van Dishoeck 1988 for a discussion of this point). Finally, the rates are given for the standard interstellar radiation field incident on a slab and need to be re-evaluated when the field in a particular application is not a simple scaling of the interstellar field (Spaans et al. 1995) or when the cloud structure is clumpy (Boissé 1991).

\subsubsection{Cosmic-ray-induced photoreactions (Nos. 3796 - 3864)}

The Prasad-Tarafdar mechanism generates an internal source of UV photons in interstellar clouds. This source of photons becomes important in regions in which the extinction of the external field is large. We have taken the appropriate probabilities, $(\gamma)$, of reaction per cosmic-ray ionisation from Gredel et al. (1987, 1989) and Rawlings (1992) who has calculated photoionisation rates for some metal ions. Note that the value of $\gamma$ for $\mathrm{CO}$ is dependent on the details of the cloud model (temperature and linewidth). The form adopted here is a fit to the temperaturedependent values listed by Gredel et al. (1987).

\section{Model results}

To facilitate the use of the rate file as a standard package, we have calculated the pseudo-time-dependent evolution of the 395 species in a dark cloud model in which $n\left(\mathrm{H}_{2}\right)=10^{4} \mathrm{~cm}^{-3}, T=10 \mathrm{~K}$, and $A_{V}=10 \mathrm{mag}-$ nitudes. We have adopted the same initial elemental abundances as in our calculation with the 1990 version: $\mathrm{H}: \mathrm{He}: \mathrm{C}: \mathrm{N}: \mathrm{O}: \mathrm{Na}: \mathrm{Mg}: \mathrm{Si}: \mathrm{P}: \mathrm{S}: \mathrm{Cl}: \mathrm{Fe}=1: 0.14: 7.310^{-5}$ : $2.1410^{-5}: 1.7610^{-4}: 2.010^{-9}: 3.010^{-9}: 3.010^{-9}$ : $3.010^{-9}: 2.010^{-8}: 4.010^{-9}: 3.010^{-9}$, and give both earlytime $\left(3.16210^{5} \mathrm{yrs}\right)$ and steady-state $\left(10^{8} \mathrm{yrs}\right)$ abundances in Table 5. In addition to the gas-phase reactions of Table 4 , we have included the grain surface formation of $\mathrm{H}_{2}$ with a rate coefficient of $9.510^{-18} \mathrm{nn}(\mathrm{H}) \mathrm{cm}^{-3} \mathrm{~s}^{-1}$.

The calculated abundances show some significant differences with those published in Millar et al. (1991b). We discuss these noting those reactions which have caused the changes and indicating the most important of these reactions which can be be studied further in the laboratory. We concentrate on the differences in steady-state results since it is more apparent which differences are caused by the new rate coefficients; at early time, differences can be caused by small changes in the time scale for chemical evolution.

\subsection{Small molecules}

The abundance of $\mathrm{C}$ atoms is an order of magnitude larger in this model. The major source of the increase in CI is due to the reaction $\mathrm{C}^{+}+\mathrm{NO} \rightarrow \mathrm{C}+\mathrm{NO}^{+}$. Although the rate coefficient for this reaction is unchanged in this revision of the ratefile, the NO abundance is larger by $\sim 100$ due to an increase in the rate coefficient of the $\mathrm{N}+\mathrm{OH} \rightarrow$ $\mathrm{NO}+\mathrm{H}$ reaction. The increase is due to an adoption of a different dependence on temperature, from $(T / 300)^{0.5}$ to $(T / 300)^{-0.25}$, an increase of $\sim 13$ at a temperature of $10 \mathrm{~K}$. This behaviour also is an indication of some of the difficulties in tracing the origin of the changes in abundances; an alteration to one rate coefficient can propagate through to species other than those directly involved in the reaction concerned. In our analysis here, we have made use of software which tabulates, for all species, the relative weights of the various formation and destruction reactions.

The $\mathrm{OH}$ abundance is also an order of magnitude larger due to a decrease in the rate coefficient of the $\mathrm{O}+\mathrm{OH} \rightarrow$ 
Table 5. Fractional abundances with respect to $\mathrm{H}_{2}$ at $3.1610^{5}$ (early time) and $10^{8}$ (steady state) years

\begin{tabular}{|c|c|c|c|c|c|c|c|c|}
\hline Species & Early time & Steady state & Species & Early time & Steady state & Species & Early time & Steady state \\
\hline$\overline{\mathrm{H}}$ & $5.957 \mathrm{e}-04$ & $1.018 \mathrm{e}-04$ & $\mathrm{He}$ & $2.801 \mathrm{e}-01$ & $2.800 \mathrm{e}-01$ & $\mathrm{C}$ & $1.314 \mathrm{e}-05$ & $1.842 \mathrm{e}-09$ \\
\hline $\mathrm{N}$ & $6.427 \mathrm{e}-06$ & $1.813 \mathrm{e}-07$ & $\mathrm{O}$ & $2.273 \mathrm{e}-04$ & $2.818 \mathrm{e}-05$ & $\mathrm{Na}$ & $1.306 \mathrm{e}-10$ & $2.135 \mathrm{e}-10$ \\
\hline $\mathrm{Mg}$ & $4.030 \mathrm{e}-10$ & $4.559 \mathrm{e}-10$ & $\mathrm{Si}$ & $1.415 \mathrm{e}-09$ & $2.264 \mathrm{e}-11$ & $\mathrm{P}$ & $3.685 \mathrm{e}-09$ & $2.791 \mathrm{e}-09$ \\
\hline $\mathrm{S}$ & $4.009 \mathrm{e}-09$ & $2.174 \mathrm{e}-09$ & $\mathrm{Cl}$ & $7.444 \mathrm{e}-09$ & $5.904 \mathrm{e}-09$ & $\mathrm{Fe}$ & $1.814 \mathrm{e}-10$ & $2.709 \mathrm{e}-10$ \\
\hline $\mathrm{H}_{2}$ & $1.000 \mathrm{e}+00$ & $1.000 \mathrm{e}+00$ & $\mathrm{CH}$ & $1.266 \mathrm{e}-08$ & $2.857 \mathrm{e}-10$ & $\mathrm{NH}$ & $6.779 \mathrm{e}-11$ & $4.560 \mathrm{e}-10$ \\
\hline $\mathrm{OH}$ & $2.102 \mathrm{e}-07$ & $9.601 \mathrm{e}-07$ & $\mathrm{SiH}$ & $2.787 \mathrm{e}-13$ & $5.825 \mathrm{e}-14$ & $\mathrm{PH}$ & $3.335 \mathrm{e}-12$ & $2.324 \mathrm{e}-11$ \\
\hline HS & $9.569 \mathrm{e}-13$ & $1.547 \mathrm{e}-11$ & $\mathrm{HCl}$ & $5.585 \mathrm{e}-10$ & $2.096 \mathrm{e}-09$ & $\mathrm{C}_{2}$ & $1.049 \mathrm{e}-08$ & $3.295 \mathrm{e}-10$ \\
\hline $\mathrm{CN}$ & $8.252 \mathrm{e}-08$ & $1.007 \mathrm{e}-10$ & $\mathrm{CO}$ & $1.147 \mathrm{e}-04$ & $1.426 \mathrm{e}-04$ & $\mathrm{SiC}$ & $2.624 \mathrm{e}-11$ & $6.969 \mathrm{e}-13$ \\
\hline $\mathrm{CP}$ & $1.752 \mathrm{e}-12$ & $8.334 \mathrm{e}-14$ & CS & $3.302 \mathrm{e}-08$ & $2.730 \mathrm{e}-09$ & $\mathrm{CCl}$ & $1.532 \mathrm{e}-14$ & $4.466 \mathrm{e}-15$ \\
\hline $\mathrm{N}_{2}$ & $1.783 \mathrm{e}-05$ & $1.960 \mathrm{e}-05$ & $\mathrm{NO}$ & $2.189 \mathrm{e}-07$ & $3.267 \mathrm{e}-06$ & $\mathrm{SiN}$ & $7.111 \mathrm{e}-13$ & $3.104 \mathrm{e}-12$ \\
\hline $\mathrm{PN}$ & $1.987 \mathrm{e}-09$ & $2.844 \mathrm{e}-10$ & NS & $9.514 \mathrm{e}-15$ & $4.543 \mathrm{e}-14$ & $\mathrm{O}_{2}$ & $1.082 \mathrm{e}-06$ & $8.424 \mathrm{e}-05$ \\
\hline $\mathrm{SiO}$ & $4.441 \mathrm{e}-09$ & $5.512 \mathrm{e}-09$ & $\mathrm{PO}$ & $3.175 \mathrm{e}-10$ & $2.898 \mathrm{e}-09$ & $\mathrm{SO}$ & $3.258 \mathrm{e}-11$ & $5.223 \mathrm{e}-09$ \\
\hline $\mathrm{ClO}$ & $0.000 \mathrm{e}+00$ & $0.000 \mathrm{e}+00$ & $\mathrm{SiS}$ & $1.020 \mathrm{e}-17$ & $3.998 \mathrm{e}-18$ & $\mathrm{~S}_{2}$ & $2.707 \mathrm{e}-18$ & $8.083 \mathrm{e}-17$ \\
\hline $\mathrm{CH}_{2}$ & $9.250 \mathrm{e}-10$ & $8.366 \mathrm{e}-12$ & $\mathrm{NH}_{2}$ & $6.170 \mathrm{e}-10$ & $3.653 \mathrm{e}-09$ & $\mathrm{H}_{2} \mathrm{O}$ & $5.927 \mathrm{e}-06$ & $2.317 \mathrm{e}-06$ \\
\hline $\mathrm{SiH}_{2}$ & $3.477 \mathrm{e}-15$ & $6.068 \mathrm{e}-15$ & $\mathrm{PH}_{2}$ & $1.863 \mathrm{e}-14$ & $3.641 \mathrm{e}-13$ & $\mathrm{H}_{2} \mathrm{~S}$ & $4.446 \mathrm{e}-12$ & $2.857 \mathrm{e}-11$ \\
\hline $\mathrm{C}_{2} \mathrm{H}$ & $2.655 \mathrm{e}-09$ & $9.229 \mathrm{e}-12$ & $\mathrm{HCN}$ & $6.780 \mathrm{e}-08$ & $3.971 \mathrm{e}-09$ & $\mathrm{HNC}$ & $3.331 \mathrm{e}-08$ & $6.849 \mathrm{e}-09$ \\
\hline $\mathrm{HCO}$ & $2.699 \mathrm{e}-10$ & $2.856 \mathrm{e}-11$ & HCSi & $5.583 \mathrm{e}-14$ & $1.258 \mathrm{e}-14$ & $\mathrm{HCP}$ & $1.403 \mathrm{e}-12$ & $5.524 \mathrm{e}-14$ \\
\hline HCS & $8.245 \mathrm{e}-13$ & $4.558 \mathrm{e}-14$ & $\mathrm{HNO}$ & $7.483 \mathrm{e}-10$ & $4.133 \mathrm{e}-09$ & HNSi & $1.369 \mathrm{e}-11$ & $1.633 \mathrm{e}-11$ \\
\hline $\mathrm{O}_{2} \mathrm{H}$ & $5.277 \mathrm{e}-13$ & $1.853 \mathrm{e}-12$ & $\mathrm{HPO}$ & $2.308 \mathrm{e}-14$ & $3.018 \mathrm{e}-13$ & $\mathrm{HS}_{2}$ & $3.349 \mathrm{e}-16$ & $5.069 \mathrm{e}-15$ \\
\hline $\mathrm{C}_{3}$ & $8.383 \mathrm{e}-09$ & $2.151 \mathrm{e}-10$ & $\mathrm{CCN}$ & $1.127 \mathrm{e}-07$ & $5.558 \mathrm{e}-11$ & $\mathrm{CCO}$ & $1.913 \mathrm{e}-10$ & $1.585 \mathrm{e}-11$ \\
\hline $\mathrm{SiC}_{2}$ & $4.566 \mathrm{e}-12$ & $1.803 \mathrm{e}-13$ & $\mathrm{CCP}$ & $1.460 \mathrm{e}-13$ & $3.121 \mathrm{e}-14$ & $\mathrm{C}_{2} \mathrm{~S}$ & $1.280 \mathrm{e}-09$ & $5.512 \mathrm{e}-11$ \\
\hline $\mathrm{OCN}$ & $3.227 \mathrm{e}-09$ & $2.366 \mathrm{e}-09$ & SiNC & $8.539 \mathrm{e}-16$ & $1.842 \mathrm{e}-17$ & $\mathrm{CO}_{2}$ & $9.977 \mathrm{e}-08$ & $3.026 \mathrm{e}-06$ \\
\hline OCS & $5.170 \mathrm{e}-11$ & $3.667 \mathrm{e}-11$ & $\mathrm{~N}_{2} \mathrm{O}$ & $2.926 \mathrm{e}-11$ & $2.757 \mathrm{e}-11$ & $\mathrm{NO}_{2}$ & $2.072 \mathrm{e}-11$ & $1.156 \mathrm{e}-10$ \\
\hline $\mathrm{SiO}_{2}$ & $3.458 \mathrm{e}-11$ & $4.310 \mathrm{e}-10$ & $\mathrm{SO}_{2}$ & $8.096 \mathrm{e}-12$ & $2.968 \mathrm{e}-08$ & $\mathrm{CH}_{3}$ & $2.182 \mathrm{e}-09$ & $2.818 \mathrm{e}-10$ \\
\hline $\mathrm{NH}_{3}$ & $4.941 \mathrm{e}-08$ & $1.379 \mathrm{e}-07$ & $\mathrm{SiH}_{3}$ & $1.884 \mathrm{e}-19$ & $8.399 \mathrm{e}-19$ & $\mathrm{C}_{2} \mathrm{H}_{2}$ & $2.333 \mathrm{e}-08$ & $6.225 \mathrm{e}-08$ \\
\hline $\mathrm{H}_{2} \mathrm{O}_{2}$ & $0.000 \mathrm{e}+00$ & $0.000 \mathrm{e}+00$ & $\mathrm{H}_{2} \mathrm{~S}_{2}$ & $1.121 \mathrm{e}-16$ & $1.686 \mathrm{e}-15$ & $\mathrm{H}_{2} \mathrm{CN}$ & $1.699 \mathrm{e}-11$ & $3.613 \mathrm{e}-13$ \\
\hline $\mathrm{H}_{2} \mathrm{CO}$ & $9.860 \mathrm{e}-07$ & $1.386 \mathrm{e}-08$ & $\mathrm{SiCH}_{2}$ & $1.211 \mathrm{e}-11$ & $7.527 \mathrm{e}-15$ & $\mathrm{H}_{2} \mathrm{CS}$ & $9.818 \mathrm{e}-10$ & $1.838 \mathrm{e}-11$ \\
\hline $\mathrm{H}_{2} \mathrm{SiO}$ & $7.792 \mathrm{e}-18$ & $2.226 \mathrm{e}-16$ & $\mathrm{C}_{3} \mathrm{H}$ & $1.142 \mathrm{e}-06$ & $2.181 \mathrm{e}-09$ & $\mathrm{SiC}_{2} \mathrm{H}$ & $6.339 \mathrm{e}-12$ & $6.101 \mathrm{e}-13$ \\
\hline $\mathrm{HCCP}$ & $2.768 \mathrm{e}-14$ & $1.516 \mathrm{e}-14$ & $\mathrm{C}_{4}$ & $5.404 \mathrm{e}-09$ & $2.865 \mathrm{e}-11$ & $\mathrm{C}_{3} \mathrm{~N}$ & $3.032 \mathrm{e}-08$ & $9.443 \mathrm{e}-12$ \\
\hline $\mathrm{C}_{3} \mathrm{O}$ & $1.619 \mathrm{e}-10$ & $1.346 \mathrm{e}-10$ & $\mathrm{SiC}_{3}$ & $1.414 \mathrm{e}-12$ & $6.108 \mathrm{e}-14$ & $\mathrm{C}_{3} \mathrm{P}$ & $7.319 \mathrm{e}-14$ & $4.053 \mathrm{e}-15$ \\
\hline $\mathrm{C}_{3} \mathrm{~S}$ & $5.478 \mathrm{e}-10$ & $8.591 \mathrm{e}-12$ & $\mathrm{CH}_{4}$ & $7.289 \mathrm{e}-06$ & $1.294 \mathrm{e}-07$ & $\mathrm{SiH}_{4}$ & $5.988 \mathrm{e}-18$ & $6.674 \mathrm{e}-18$ \\
\hline $\mathrm{C}_{2} \mathrm{H}_{3}$ & $1.967 \mathrm{e}-11$ & $1.534 \mathrm{e}-13$ & $\mathrm{CH}_{2} \mathrm{NH}$ & $1.908 \mathrm{e}-18$ & $3.668 \mathrm{e}-22$ & $\mathrm{SiCH}_{3}$ & $4.115 \mathrm{e}-12$ & $2.392 \mathrm{e}-15$ \\
\hline $\mathrm{CH}_{2} \mathrm{PH}$ & $7.341 \mathrm{e}-15$ & $1.219 \mathrm{e}-15$ & $\mathrm{H}_{2} \mathrm{C}_{3}$ & $2.612 \mathrm{e}-10$ & $2.431 \mathrm{e}-10$ & $\mathrm{C}_{3} \mathrm{H}_{2}$ & $9.579 \mathrm{e}-09$ & $5.717 \mathrm{e}-09$ \\
\hline $\mathrm{CH}_{2} \mathrm{CN}$ & $5.246 \mathrm{e}-08$ & $7.546 \mathrm{e}-11$ & $\mathrm{CH}_{2} \mathrm{CO}$ & $1.015 \mathrm{e}-07$ & $3.899 \mathrm{e}-10$ & $\mathrm{SiC}_{2} \mathrm{H}_{2}$ & $3.076 \mathrm{e}-12$ & $3.583 \mathrm{e}-13$ \\
\hline $\mathrm{CHOOH}$ & $2.575 \mathrm{e}-08$ & $2.583 \mathrm{e}-08$ & $\mathrm{C}_{4} \mathrm{H}$ & $8.634 \mathrm{e}-07$ & 7.133e-09 & $\mathrm{HC}_{3} \mathrm{~N}$ & $3.849 \mathrm{e}-08$ & $1.719 \mathrm{e}-10$ \\
\hline $\mathrm{SiC}_{3} \mathrm{H}$ & $7.301 \mathrm{e}-12$ & $6.889 \mathrm{e}-15$ & $\mathrm{C}_{5}$ & $4.235 \mathrm{e}-09$ & $3.164 \mathrm{e}-11$ & $\mathrm{SiC}_{4}$ & $6.166 \mathrm{e}-15$ & $8.828 \mathrm{e}-18$ \\
\hline $\mathrm{C}_{4} \mathrm{P}$ & $3.893 \mathrm{e}-14$ & $2.976 \mathrm{e}-15$ & $\mathrm{C}_{4} \mathrm{~S}$ & $1.254 \mathrm{e}-11$ & $1.548 \mathrm{e}-13$ & $\mathrm{C}_{2} \mathrm{H}_{4}$ & $4.487 \mathrm{e}-10$ & $1.190 \mathrm{e}-11$ \\
\hline $\mathrm{CH}_{3} \mathrm{OH}$ & $1.544 \mathrm{e}-07$ & $7.024 \mathrm{e}-10$ & $\mathrm{C}_{3} \mathrm{H}_{3}$ & $1.845 \mathrm{e}-08$ & $1.499 \mathrm{e}-11$ & $\mathrm{CH}_{3} \mathrm{CN}$ & $1.859 \mathrm{e}-08$ & $8.902 \mathrm{e}-12$ \\
\hline $\mathrm{C}_{4} \mathrm{H}_{2}$ & $4.029 \mathrm{e}-11$ & $2.874 \mathrm{e}-11$ & $\mathrm{C}_{5} \mathrm{H}$ & $2.435 \mathrm{e}-08$ & $3.980 \mathrm{e}-11$ & $\mathrm{C}_{6}$ & $2.524 \mathrm{e}-09$ & $6.535 \mathrm{e}-12$ \\
\hline $\mathrm{C}_{5} \mathrm{~N}$ & $8.448 \mathrm{e}-10$ & $4.236 \mathrm{e}-13$ & $\mathrm{C}_{2} \mathrm{H}_{5}$ & $6.596 \mathrm{e}-16$ & $3.240 \mathrm{e}-17$ & $\mathrm{C}_{3} \mathrm{H}_{4}$ & $2.904 \mathrm{e}-11$ & $8.753 \mathrm{e}-12$ \\
\hline $\mathrm{CH}_{3} \mathrm{CHO}$ & $2.622 \mathrm{e}-10$ & $3.961 \mathrm{e}-10$ & $\mathrm{H}_{3} \mathrm{C}_{3} \mathrm{~N}$ & $1.305 \mathrm{e}-10$ & $1.005 \mathrm{e}-14$ & $\mathrm{C}_{5} \mathrm{H}_{2}$ & $1.331 \mathrm{e}-10$ & $2.915 \mathrm{e}-11$ \\
\hline $\mathrm{C}_{6} \mathrm{H}$ & $1.545 \mathrm{e}-07$ & $4.490 \mathrm{e}-11$ & $\mathrm{HC}_{5} \mathrm{~N}$ & $1.433 \mathrm{e}-09$ & $4.408 \mathrm{e}-13$ & $\mathrm{C}_{7}$ & $1.075 \mathrm{e}-09$ & $1.652 \mathrm{e}-12$ \\
\hline $\mathrm{C}_{2} \mathrm{H}_{6}$ & $4.955 \mathrm{e}-20$ & $4.299 \mathrm{e}-20$ & $\mathrm{HCOOCH}_{3}$ & $3.324 \mathrm{e}-11$ & $2.943 \mathrm{e}-15$ & $\mathrm{H}_{3} \mathrm{C}_{4} \mathrm{~N}$ & $3.651 \mathrm{e}-10$ & $3.805 \mathrm{e}-14$ \\
\hline $\mathrm{C}_{6} \mathrm{H}_{2}$ & $9.583 \mathrm{e}-11$ & $1.472 \mathrm{e}-11$ & $\mathrm{C}_{7} \mathrm{H}$ & $2.276 \mathrm{e}-08$ & $5.968 \mathrm{e}-12$ & $\mathrm{C}_{8}$ & $5.126 \mathrm{e}-10$ & $3.882 \mathrm{e}-13$ \\
\hline $\mathrm{C}_{7} \mathrm{~N}$ & $1.077 \mathrm{e}-10$ & $5.256 \mathrm{e}-14$ & $\mathrm{CH}_{3} \mathrm{OCH}_{3}$ & $4.353 \mathrm{e}-09$ & $1.921 \mathrm{e}-13$ & $\mathrm{C}_{2} \mathrm{H}_{5} \mathrm{OH}$ & $3.743 \mathrm{e}-12$ & $6.971 \mathrm{e}-14$ \\
\hline $\mathrm{C}_{5} \mathrm{H}_{4}$ & $4.834 \mathrm{e}-11$ & $2.398 \mathrm{e}-12$ & $\mathrm{C}_{7} \mathrm{H}_{2}$ & $1.401 \mathrm{e}-11$ & $2.681 \mathrm{e}-12$ & $\mathrm{C}_{8} \mathrm{H}$ & $2.060 \mathrm{e}-08$ & $2.338 \mathrm{e}-12$ \\
\hline $\mathrm{HC}_{7} \mathrm{~N}$ & $7.085 \mathrm{e}-10$ & $6.667 \mathrm{e}-14$ & $\mathrm{C}_{9}$ & $1.408 \mathrm{e}-10$ & $2.857 \mathrm{e}-14$ & $\mathrm{C}_{2} \mathrm{H}_{6} \mathrm{CO}$ & $1.710 \mathrm{e}-13$ & $2.331 \mathrm{e}-15$ \\
\hline $\mathrm{H}_{3} \mathrm{C}_{6} \mathrm{~N}$ & $3.030 \mathrm{e}-11$ & $7.363 \mathrm{e}-17$ & $\mathrm{C}_{8} \mathrm{H}_{2}$ & $9.670 \mathrm{e}-12$ & $1.089 \mathrm{e}-13$ & $\mathrm{C}_{9} \mathrm{H}$ & $2.850 \mathrm{e}-09$ & $6.051 \mathrm{e}-14$ \\
\hline $\mathrm{C}_{9} \mathrm{~N}$ & $7.549 \mathrm{e}-12$ & $1.633 \mathrm{e}-16$ & $\mathrm{C}_{7} \mathrm{H}_{4}$ & $1.012 \mathrm{e}-11$ & $2.745 \mathrm{e}-14$ & $\mathrm{C}_{9} \mathrm{H}_{2}$ & $5.902 \mathrm{e}-10$ & $2.959 \mathrm{e}-14$ \\
\hline $\mathrm{HC}_{9} \mathrm{~N}$ & $6.258 \mathrm{e}-11$ & $2.065 \mathrm{e}-16$ & $\mathrm{H}_{3} \mathrm{C}_{8} \mathrm{~N}$ & $1.074 \mathrm{e}-11$ & $1.062 \mathrm{e}-17$ & $\mathrm{H}^{-}$ & $5.453 \mathrm{e}-13$ & $1.404 \mathrm{e}-12$ \\
\hline $\mathrm{C}^{-}$ & $3.206 \mathrm{e}-15$ & $1.013 \mathrm{e}-18$ & $\mathrm{O}^{-}$ & $2.134 \mathrm{e}-17$ & $2.531 \mathrm{e}-18$ & $\mathrm{~S}^{-}$ & $5.883 \mathrm{e}-18$ & $5.418 \mathrm{e}-18$ \\
\hline $\mathrm{OH}^{-}$ & $1.526 \mathrm{e}-14$ & $8.378 \mathrm{e}-14$ & $\mathrm{CN}^{-}$ & $1.841 \mathrm{e}-16$ & $1.562 \mathrm{e}-16$ & $\mathrm{H}^{+}$ & $5.968 \mathrm{e}-10$ & $2.241 \mathrm{e}-10$ \\
\hline $\mathrm{He}^{+}$ & $1.443 \mathrm{e}-09$ & $9.921 \mathrm{e}-10$ & $\mathrm{C}^{+}$ & $7.240 \mathrm{e}-09$ & $2.313 \mathrm{e}-09$ & $\mathrm{~N}^{+}$ & $7.385 \mathrm{e}-11$ & $5.725 \mathrm{e}-11$ \\
\hline $\mathrm{O}^{+}$ & $4.938 \mathrm{e}-15$ & $1.216 \mathrm{e}-13$ & $\mathrm{Na}^{+}$ & $3.871 \mathrm{e}-09$ & $3.787 \mathrm{e}-09$ & $\mathrm{Mg}^{+}$ & $5.599 \mathrm{e}-09$ & $5.544 \mathrm{e}-09$ \\
\hline $\mathrm{Si}^{+}$ & $2.797 \mathrm{e}-11$ & $1.058 \mathrm{e}-11$ & $\mathrm{P}^{+}$ & $3.189 \mathrm{e}-12$ & $2.604 \mathrm{e}-13$ & $\mathrm{~S}^{+}$ & $2.412 \mathrm{e}-11$ & $1.720 \mathrm{e}-11$ \\
\hline $\mathrm{Cl}^{+}$ & $2.718 \mathrm{e}-18$ & $6.907 \mathrm{e}-18$ & $\mathrm{Fe}^{+}$ & $5.821 \mathrm{e}-09$ & $5.729 \mathrm{e}-09$ & $\mathrm{H}_{2}^{+}$ & $1.139 \mathrm{e}-12$ & $1.137 \mathrm{e}-12$ \\
\hline $\mathrm{HeH}^{+}$ & $2.763 \mathrm{e}-14$ & $2.759 \mathrm{e}-14$ & $\mathrm{CH}^{+}$ & $2.053 \mathrm{e}-13$ & $1.150 \mathrm{e}-16$ & $\mathrm{NH}^{+}$ & $1.002 \mathrm{e}-14$ & $7.759 \mathrm{e}-15$ \\
\hline $\mathrm{OH}^{+}$ & $8.706 \mathrm{e}-13$ & $3.686 \mathrm{e}-13$ & $\mathrm{SiH}^{+}$ & $4.106 \mathrm{e}-14$ & $4.610 \mathrm{e}-15$ & $\mathrm{PH}^{+}$ & $1.939 \mathrm{e}-13$ & $5.856 \mathrm{e}-13$ \\
\hline $\mathrm{HS}^{+}$ & $2.498 \mathrm{e}-13$ & $6.406 \mathrm{e}-13$ & $\mathrm{HCl}^{+}$ & $2.948 \mathrm{e}-17$ & $3.854 \mathrm{e}-17$ & $\mathrm{C}_{2}^{+}$ & $3.435 \mathrm{e}-16$ & $7.171 \mathrm{e}-17$ \\
\hline $\mathrm{CN}^{+}$ & $2.208 \mathrm{e}-16$ & $1.703 \mathrm{e}-17$ & $\mathrm{CO}^{+}$ & $9.220 \mathrm{e}-15$ & $5.227 \mathrm{e}-14$ & $\mathrm{SiC}^{+}$ & $5.752 \mathrm{e}-19$ & $9.203 \mathrm{e}-21$ \\
\hline
\end{tabular}


Table 5. continued

\begin{tabular}{|c|c|c|c|c|c|c|c|c|}
\hline Species & Early time & Steady state & Species & Early time & Steady state & Species & Early time & Steady state \\
\hline $\mathrm{CP}^{+}$ & $1.438 \mathrm{e}-20$ & $2.726 \mathrm{e}-22$ & $\mathrm{CS}^{+}$ & $2.144 \mathrm{e}-16$ & $1.330 \mathrm{e}-17$ & $\mathrm{CCl}^{+}$ & $5.920 \mathrm{e}-14$ & $7.417 \mathrm{e}-14$ \\
\hline $\mathrm{N}_{2}^{+}$ & $8.237 \mathrm{e}-15$ & $6.228 \mathrm{e}-15$ & $\mathrm{NO}^{+}$ & $3.808 \mathrm{e}-11$ & $1.503 \mathrm{e}-10$ & $\mathrm{SiN}^{+}$ & $1.450 \mathrm{e}-15$ & $7.587 \mathrm{e}-16$ \\
\hline $\mathrm{PN}^{+}$ & $1.143 \mathrm{e}-14$ & $1.307 \mathrm{e}-15$ & $\mathrm{NS}^{+}$ & $7.704 \mathrm{e}-15$ & $2.294 \mathrm{e}-15$ & $\mathrm{O}_{2}^{+}$ & $1.332 \mathrm{e}-11$ & $4.472 \mathrm{e}-10$ \\
\hline $\mathrm{SiO}^{+}$ & $5.158 \mathrm{e}-17$ & $3.322 \mathrm{e}-17$ & $\mathrm{PO}^{+}$ & $1.118 \mathrm{e}-12$ & $1.461 \mathrm{e}-12$ & $\mathrm{SO}^{+}$ & $4.360 \mathrm{e}-13$ & $6.279 \mathrm{e}-12$ \\
\hline $\mathrm{ClO}^{+}$ & $0.000 \mathrm{e}+00$ & $0.000 \mathrm{e}+00$ & $\mathrm{SiS}^{+}$ & $1.104 \mathrm{e}-18$ & $1.449 \mathrm{e}-18$ & $\mathrm{~S}_{2}^{+}$ & $1.409 \mathrm{e}-18$ & $1.073 \mathrm{e}-17$ \\
\hline $\mathrm{H}_{3}^{+}$ & $4.686 \mathrm{e}-09$ & $7.142 \mathrm{e}-09$ & $\mathrm{CH}_{2}^{+}$ & $1.761 \mathrm{e}-13$ & $1.369 \mathrm{e}-15$ & $\mathrm{NH}_{2}^{+}$ & $4.793 \mathrm{e}-14$ & $3.772 \mathrm{e}-14$ \\
\hline $\mathrm{H}_{2} \mathrm{O}^{+}$ & $1.094 \mathrm{e}-12$ & $4.745 \mathrm{e}-13$ & $\mathrm{SiH}_{2}^{+}$ & $3.159 \mathrm{e}-16$ & $2.392 \mathrm{e}-16$ & $\mathrm{PH}_{2}^{+}$ & $2.369 \mathrm{e}-14$ & $1.003 \mathrm{e}-14$ \\
\hline $\mathrm{H}_{2} \mathrm{~S}^{+}$ & $2.453 \mathrm{e}-14$ & $1.020 \mathrm{e}-14$ & $\mathrm{H}_{2} \mathrm{Cl}^{+}$ & $2.735 \mathrm{e}-13$ & $5.698 \mathrm{e}-13$ & $\mathrm{C}_{2} \mathrm{H}^{+}$ & $5.704 \mathrm{e}-15$ & $1.362 \mathrm{e}-16$ \\
\hline $\mathrm{HCN}^{+}$ & $1.674 \mathrm{e}-15$ & $6.732 \mathrm{e}-17$ & $\mathrm{HCO}^{+}$ & $6.991 \mathrm{e}-09$ & $1.329 \mathrm{e}-08$ & $\mathrm{HOC}^{+}$ & $7.057 \mathrm{e}-14$ & $2.856 \mathrm{e}-14$ \\
\hline $\mathrm{HCSi}^{+}$ & $1.486 \mathrm{e}-18$ & $3.693 \mathrm{e}-20$ & $\mathrm{HCP}^{+}$ & $4.919 \mathrm{e}-20$ & $2.252 \mathrm{e}-21$ & $\mathrm{HCS}^{+}$ & $3.138 \mathrm{e}-11$ & $3.958 \mathrm{e}-12$ \\
\hline $\mathrm{N}_{2} \mathrm{H}^{+}$ & $4.921 \mathrm{e}-10$ & $8.862 \mathrm{e}-10$ & $\mathrm{HNO}^{+}$ & $9.867 \mathrm{e}-12$ & $2.700 \mathrm{e}-10$ & $\mathrm{HNSi}^{+}$ & $1.925 \mathrm{e}-20$ & $4.981 \mathrm{e}-20$ \\
\hline $\mathrm{HPN}^{+}$ & $4.360 \mathrm{e}-13$ & $9.035 \mathrm{e}-14$ & $\mathrm{HNS}^{+}$ & $3.762 \mathrm{e}-18$ & $2.238 \mathrm{e}-17$ & $\mathrm{O}_{2} \mathrm{H}^{+}$ & $3.671 \mathrm{e}-18$ & $2.859 \mathrm{e}-16$ \\
\hline $\mathrm{SiOH}^{+}$ & $2.177 \mathrm{e}-12$ & $2.495 \mathrm{e}-12$ & $\mathrm{HPO}^{+}$ & $2.107 \mathrm{e}-13$ & $6.477 \mathrm{e}-13$ & $\mathrm{HSO}^{+}$ & $9.224 \mathrm{e}-15$ & $2.565 \mathrm{e}-12$ \\
\hline $\mathrm{HSiS}^{+}$ & $2.721 \mathrm{e}-20$ & $1.386 \mathrm{e}-20$ & $\mathrm{~S}_{2} \mathrm{H}^{+}$ & $6.126 \mathrm{e}-20$ & $3.089 \mathrm{e}-19$ & $\mathrm{C}_{3}^{+}$ & $1.601 \mathrm{e}-14$ & $2.075 \mathrm{e}-17$ \\
\hline $\mathrm{CCN}^{+}$ & $1.563 \mathrm{e}-11$ & $6.812 \mathrm{e}-13$ & $\mathrm{CNC}^{+}$ & $2.025 \mathrm{e}-11$ & $3.960 \mathrm{e}-13$ & $\mathrm{C}_{2} \mathrm{O}^{+}$ & $1.996 \mathrm{e}-14$ & $5.594 \mathrm{e}-16$ \\
\hline $\mathrm{SiC}_{2}^{+}$ & $1.781 \mathrm{e}-19$ & $1.374 \mathrm{e}-21$ & $\mathrm{CCP}^{+}$ & $7.750 \mathrm{e}-17$ & $1.752 \mathrm{e}-18$ & $\mathrm{C}_{2} \mathrm{~S}^{+}$ & $5.488 \mathrm{e}-18$ & $7.642 \mathrm{e}-20$ \\
\hline $\mathrm{NCO}^{+}$ & $8.245 \mathrm{e}-15$ & $8.299 \mathrm{e}-15$ & $\mathrm{SiNC}^{+}$ & $1.273 \mathrm{e}-14$ & $1.986 \mathrm{e}-15$ & $\mathrm{CO}_{2}^{+}$ & $2.415 \mathrm{e}-17$ & $5.193 \mathrm{e}-16$ \\
\hline $\mathrm{OCS}^{+}$ & $4.778 \mathrm{e}-13$ & $8.502 \mathrm{e}-15$ & $\mathrm{NO}_{2}^{+}$ & $1.494 \mathrm{e}-17$ & $5.135 \mathrm{e}-17$ & $\mathrm{SO}_{2}^{+}$ & $1.927 \mathrm{e}-18$ & $2.984 \mathrm{e}-15$ \\
\hline $\mathrm{CH}_{3}^{+}$ & $4.771 \mathrm{e}-10$ & $4.610 \mathrm{e}-12$ & $\mathrm{NH}_{3}^{+}$ & $6.331 \mathrm{e}-12$ & $5.130 \mathrm{e}-12$ & $\mathrm{H}_{3} \mathrm{O}^{+}$ & $4.811 \mathrm{e}-09$ & $2.404 \mathrm{e}-09$ \\
\hline $\mathrm{SiH}_{3}^{+}$ & $2.180 \mathrm{e}-16$ & $5.304 \mathrm{e}-17$ & $\mathrm{PH}_{3}^{+}$ & $7.234 \mathrm{e}-15$ & $2.289 \mathrm{e}-14$ & $\mathrm{H}_{3} \mathrm{~S}^{+}$ & $8.269 \mathrm{e}-15$ & $4.029 \mathrm{e}-14$ \\
\hline $\mathrm{C}_{2} \mathrm{H}_{2}^{+}$ & $6.201 \mathrm{e}-12$ & $7.846 \mathrm{e}-14$ & $\mathrm{HCNH}^{+}$ & $1.096 \mathrm{e}-10$ & $1.471 \mathrm{e}-11$ & $\mathrm{H}_{2} \mathrm{NC}^{+}$ & $1.686 \mathrm{e}-11$ & $1.176 \mathrm{e}-11$ \\
\hline $\mathrm{H}_{2} \mathrm{CO}^{+}$ & $7.810 \mathrm{e}-11$ & $4.457 \mathrm{e}-13$ & $\mathrm{SiCH}_{2}^{+}$ & $7.236 \mathrm{e}-15$ & $4.053 \mathrm{e}-16$ & $\mathrm{PCH}_{2}^{+}$ & $3.215 \mathrm{e}-13$ & $6.782 \mathrm{e}-16$ \\
\hline $\mathrm{H}_{2} \mathrm{C}^{+}$ & $1.838 \mathrm{e}-14$ & $1.400 \mathrm{e}-16$ & $\mathrm{H}_{2} \mathrm{CCl}^{+}$ & $4.614 \mathrm{e}-15$ & $1.747 \mathrm{e}-16$ & $\mathrm{H}_{2} \mathrm{NO}^{+}$ & $9.342 \mathrm{e}-14$ & $8.265 \mathrm{e}-13$ \\
\hline $\mathrm{SiNH}_{2}^{+}$ & $1.743 \mathrm{e}-14$ & $2.406 \mathrm{e}-14$ & $\mathrm{PNH}_{2}^{+}$ & $9.396 \mathrm{e}-16$ & $5.462 \mathrm{e}-16$ & $\mathrm{H}_{2} \mathrm{SiO}^{+}$ & $1.319 \mathrm{e}-16$ & $4.174 \mathrm{e}-18$ \\
\hline $\mathrm{H}_{2} \mathrm{PO}^{+}$ & $3.681 \mathrm{e}-15$ & $3.977 \mathrm{e}-15$ & $\mathrm{H}_{2} \mathrm{~S}_{2}^{+}$ & $5.906 \mathrm{e}-19$ & $4.455 \mathrm{e}-18$ & $\mathrm{C}_{3} \mathrm{H}^{+}$ & $1.286 \mathrm{e}-13$ & $3.400 \mathrm{e}-15$ \\
\hline $\mathrm{CCNH}^{+}$ & $6.970 \mathrm{e}-11$ & $6.687 \mathrm{e}-14$ & $\mathrm{HC}_{2} \mathrm{O}^{+}$ & $1.496 \mathrm{e}-10$ & $1.620 \mathrm{e}-12$ & $\mathrm{C}_{2} \mathrm{HO}^{+}$ & $1.596 \mathrm{e}-12$ & $2.631 \mathrm{e}-15$ \\
\hline $\mathrm{SiC}_{2} \mathrm{H}^{+}$ & $9.784 \mathrm{e}-15$ & $2.191 \mathrm{e}-15$ & $\mathrm{PC}_{2} \mathrm{H}^{+}$ & $1.564 \mathrm{e}-15$ & $2.925 \mathrm{e}-16$ & $\mathrm{HC}_{2} \mathrm{~S}^{+}$ & $3.297 \mathrm{e}-13$ & $3.368 \mathrm{e}-14$ \\
\hline $\mathrm{HNCO}^{+}$ & $1.115 \mathrm{e}-17$ & $3.513 \mathrm{e}-19$ & $\mathrm{SiNCH}^{+}$ & $2.058 \mathrm{e}-16$ & $6.024 \mathrm{e}-19$ & $\mathrm{HCO}_{2}^{+}$ & $5.703 \mathrm{e}-12$ & $2.613 \mathrm{e}-10$ \\
\hline $\mathrm{HOCS}^{+}$ & $8.710 \mathrm{e}-15$ & $1.102 \mathrm{e}-14$ & $\mathrm{HSiO}_{2}^{+}$ & $1.074 \mathrm{e}-14$ & $2.450 \mathrm{e}-13$ & $\mathrm{HSO}_{2}^{+}$ & $7.265 \mathrm{e}-16$ & $3.229 \mathrm{e}-12$ \\
\hline $\mathrm{C}_{4}^{+}$ & $4.432 \mathrm{e}-14$ & $9.769 \mathrm{e}-17$ & $\mathrm{C}_{3} \mathrm{~N}^{+}$ & $3.300 \mathrm{e}-16$ & $3.298 \mathrm{e}-19$ & $\mathrm{C}_{3} \mathrm{O}^{+}$ & $6.483 \mathrm{e}-15$ & $1.862 \mathrm{e}-15$ \\
\hline $\mathrm{SiC}_{3}^{+}$ & $4.277 \mathrm{e}-13$ & $3.454 \mathrm{e}-16$ & $\mathrm{C}_{3} \mathrm{~S}^{+}$ & $4.551 \mathrm{e}-13$ & $6.878 \mathrm{e}-16$ & $\mathrm{C}_{2} \mathrm{~N}_{2}^{+}$ & $6.276 \mathrm{e}-20$ & $2.964 \mathrm{e}-22$ \\
\hline $\mathrm{CH}_{4}^{+}$ & $4.963 \mathrm{e}-13$ & $2.518 \mathrm{e}-15$ & $\mathrm{NH}_{4}^{+}$ & $3.113 \mathrm{e}-11$ & $3.947 \mathrm{e}-11$ & $\mathrm{SiH}_{4}^{+}$ & $7.124 \mathrm{e}-27$ & $1.424 \mathrm{e}-26$ \\
\hline $\mathrm{C}_{2} \mathrm{H}_{3}^{+}$ & $3.294 \mathrm{e}-10$ & $2.742 \mathrm{e}-11$ & $\mathrm{H}_{3} \mathrm{CO}^{+}$ & $4.959 \mathrm{e}-10$ & $9.645 \mathrm{e}-12$ & $\mathrm{SiCH}_{3}^{+}$ & $6.055 \mathrm{e}-15$ & $4.954 \mathrm{e}-18$ \\
\hline $\mathrm{PCH}_{3}^{+}$ & $1.035 \mathrm{e}-14$ & $5.800 \mathrm{e}-16$ & $\mathrm{H}_{3} \mathrm{CS}^{+}$ & $5.868 \mathrm{e}-13$ & $1.059 \mathrm{e}-14$ & $\mathrm{PNH}_{3}^{+}$ & $8.259 \mathrm{e}-17$ & $6.332 \mathrm{e}-16$ \\
\hline $\mathrm{H}_{3} \mathrm{SiO}^{+}$ & $1.605 \mathrm{e}-20$ & $3.220 \mathrm{e}-19$ & $\mathrm{H}_{3} \mathrm{~S}_{2}^{+}$ & 2.937e-19 & $2.360 \mathrm{e}-18$ & $\mathrm{C}_{3} \mathrm{H}_{2}^{+}$ & $2.019 \mathrm{e}-10$ & $7.044 \mathrm{e}-13$ \\
\hline $\mathrm{CH}_{2} \mathrm{CN}^{+}$ & $1.331 \mathrm{e}-11$ & $6.345 \mathrm{e}-15$ & $\mathrm{CH}_{2} \mathrm{CO}^{+}$ & $9.790 \mathrm{e}-12$ & $1.288 \mathrm{e}-14$ & $\mathrm{SiC}_{2} \mathrm{H}_{2}^{+}$ & $5.116 \mathrm{e}-15$ & $4.189 \mathrm{e}-16$ \\
\hline $\mathrm{PC}_{2} \mathrm{H}_{2}^{+}$ & $1.768 \mathrm{e}-16$ & $6.898 \mathrm{e}-16$ & $\mathrm{C}_{4} \mathrm{H}^{+}$ & $2.824 \mathrm{e}-14$ & $6.819 \mathrm{e}-17$ & $\mathrm{HC}_{3} \mathrm{~N}^{+}$ & $4.294 \mathrm{e}-13$ & $2.489 \mathrm{e}-16$ \\
\hline $\mathrm{HC}_{3} \mathrm{O}^{+}$ & $6.094 \mathrm{e}-14$ & $8.105 \mathrm{e}-14$ & $\mathrm{SiC}_{3} \mathrm{H}^{+}$ & $6.119 \mathrm{e}-15$ & $9.370 \mathrm{e}-16$ & $\mathrm{PC}_{3} \mathrm{H}^{+}$ & $9.918 \mathrm{e}-15$ & $2.864 \mathrm{e}-17$ \\
\hline $\mathrm{HC}_{3} \mathrm{~S}^{+}$ & $1.428 \mathrm{e}-13$ & $5.049 \mathrm{e}-15$ & $\mathrm{C}_{5}^{+}$ & $1.153 \mathrm{e}-14$ & $2.290 \mathrm{e}-17$ & $\mathrm{C}_{4} \mathrm{~N}^{+}$ & $1.514 \mathrm{e}-14$ & $2.161 \mathrm{e}-17$ \\
\hline $\mathrm{SiC}_{4}^{+}$ & $3.244 \mathrm{e}-13$ & $1.051 \mathrm{e}-15$ & $\mathrm{C}_{4} \mathrm{P}^{+}$ & $3.093 \mathrm{e}-19$ & $9.275 \mathrm{e}-21$ & $\mathrm{C}_{4} \mathrm{~S}^{+}$ & $2.780 \mathrm{e}-13$ & $1.710 \mathrm{e}-15$ \\
\hline $\mathrm{CH}_{5}^{+}$ & 7.992e-10 & $1.438 \mathrm{e}-11$ & $\mathrm{SiH}_{5}^{+}$ & $1.171 \mathrm{e}-20$ & $6.608 \mathrm{e}-21$ & $\mathrm{C}_{2} \mathrm{H}_{4}^{+}$ & $1.571 \mathrm{e}-10$ & $3.871 \mathrm{e}-12$ \\
\hline $\mathrm{CH}_{4} \mathrm{~N}^{+}$ & $3.434 \mathrm{e}-13$ & $9.784 \mathrm{e}-15$ & $\mathrm{CH}_{2} \mathrm{NH}_{2}^{+}$ & $1.727 \mathrm{e}-17$ & $3.470 \mathrm{e}-21$ & $\mathrm{CH}_{3} \mathrm{OH}^{+}$ & $2.038 \mathrm{e}-13$ & $2.879 \mathrm{e}-15$ \\
\hline $\mathrm{SiCH}_{4}^{+}$ & $4.830 \mathrm{e}-15$ & $3.678 \mathrm{e}-18$ & $\mathrm{PCH}_{4}^{+}$ & $1.783 \mathrm{e}-15$ & $3.913 \mathrm{e}-17$ & $\mathrm{C}_{3} \mathrm{H}_{3}^{+}$ & $7.634 \mathrm{e}-11$ & $2.265 \mathrm{e}-11$ \\
\hline $\mathrm{H}_{2} \mathrm{C}_{3} \mathrm{H}^{+}$ & $8.520 \mathrm{e}-11$ & $6.167 \mathrm{e}-12$ & $\mathrm{CH}_{3} \mathrm{CN}^{+}$ & $3.318 \mathrm{e}-12$ & $5.781 \mathrm{e}-15$ & $\mathrm{CH}_{3} \mathrm{CO}^{+}$ & $4.877 \mathrm{e}-11$ & $2.478 \mathrm{e}-13$ \\
\hline $\mathrm{SiC}_{2} \mathrm{H}_{3}^{+}$ & $2.954 \mathrm{e}-15$ & $4.800 \mathrm{e}-16$ & $\mathrm{PC}_{2} \mathrm{H}_{3}^{+}$ & $2.274 \mathrm{e}-18$ & $1.158 \mathrm{e}-17$ & $\mathrm{CHOOH}_{2}^{+}$ & $2.490 \mathrm{e}-11$ & $2.425 \mathrm{e}-11$ \\
\hline $\mathrm{C}_{4} \mathrm{H}_{2}^{+}$ & $3.063 \mathrm{e}-10$ & $3.880 \mathrm{e}-12$ & $\mathrm{H}_{2} \mathrm{C}_{3} \mathrm{~N}^{+}$ & $3.875 \mathrm{e}-11$ & $1.653 \mathrm{e}-13$ & $\mathrm{C}_{3} \mathrm{H}_{2} \mathrm{O}^{+}$ & $9.380 \mathrm{e}-15$ & $1.541 \mathrm{e}-16$ \\
\hline $\mathrm{SiC}_{3} \mathrm{H}_{2}^{+}$ & $9.533 \mathrm{e}-15$ & $9.229 \mathrm{e}-18$ & $\mathrm{C}_{5} \mathrm{H}^{+}$ & $4.093 \mathrm{e}-11$ & $9.152 \mathrm{e}-14$ & $\mathrm{HC}_{4} \mathrm{~N}^{+}$ & $7.294 \mathrm{e}-20$ & $8.481 \mathrm{e}-21$ \\
\hline $\mathrm{SiC}_{4} \mathrm{H}^{+}$ & $1.490 \mathrm{e}-15$ & $2.875 \mathrm{e}-19$ & $\mathrm{PC}_{4} \mathrm{H}^{+}$ & $1.890 \mathrm{e}-14$ & $1.905 \mathrm{e}-16$ & $\mathrm{HC}_{4} \mathrm{~S}^{+}$ & $1.914 \mathrm{e}-14$ & $1.703 \mathrm{e}-16$ \\
\hline $\mathrm{C}_{6}^{+}$ & $2.422 \mathrm{e}-14$ & $7.605 \mathrm{e}-18$ & $\mathrm{C}_{5} \mathrm{~N}^{+}$ & $3.507 \mathrm{e}-17$ & $2.212 \mathrm{e}-21$ & $\mathrm{C}_{2} \mathrm{H}_{5}^{+}$ & $2.096 \mathrm{e}-11$ & $5.692 \mathrm{e}-15$ \\
\hline $\mathrm{CH}_{3} \mathrm{OH}_{2}^{+}$ & $1.553 \mathrm{e}-10$ & $8.935 \mathrm{e}-13$ & $\mathrm{C}_{3} \mathrm{H}_{4}^{+}$ & $3.161 \mathrm{e}-12$ & $5.739 \mathrm{e}-15$ & $\mathrm{H}_{4} \mathrm{C}_{2} \mathrm{~N}^{+}$ & $3.902 \mathrm{e}-11$ & $2.337 \mathrm{e}-14$ \\
\hline $\mathrm{CH}_{3} \mathrm{CHO}^{+}$ & $4.539 \mathrm{e}-14$ & $2.356 \mathrm{e}-14$ & $\mathrm{PC}_{2} \mathrm{H}_{4}^{+}$ & $1.556 \mathrm{e}-19$ & $1.826 \mathrm{e}-21$ & $\mathrm{C}_{4} \mathrm{H}_{3}^{+}$ & $5.794 \mathrm{e}-13$ & $1.612 \mathrm{e}-14$ \\
\hline $\mathrm{H}_{3} \mathrm{C}_{3} \mathrm{O}^{+}$ & $4.960 \mathrm{e}-12$ & $5.363 \mathrm{e}-13$ & $\mathrm{C}_{5} \mathrm{H}_{2}^{+}$ & $1.575 \mathrm{e}-11$ & $3.720 \mathrm{e}-14$ & $\mathrm{H}_{2} \mathrm{C}_{4} \mathrm{~N}^{+}$ & $1.197 \mathrm{e}-18$ & $8.508 \mathrm{e}-21$ \\
\hline $\mathrm{PC}_{4} \mathrm{H}_{2}^{+}$ & $4.415 \mathrm{e}-19$ & $2.305 \mathrm{e}-19$ & $\mathrm{C}_{6} \mathrm{H}^{+}$ & $1.752 \mathrm{e}-12$ & $7.330 \mathrm{e}-16$ & $\mathrm{HC}_{5} \mathrm{~N}^{+}$ & $1.257 \mathrm{e}-16$ & $4.615 \mathrm{e}-20$ \\
\hline $\mathrm{C}_{7}^{+}$ & $2.575 \mathrm{e}-15$ & $5.115 \mathrm{e}-19$ & $\mathrm{C}_{2} \mathrm{H}_{6}^{+}$ & $1.163 \mathrm{e}-19$ & $1.173 \mathrm{e}-20$ & $\mathrm{C}_{3} \mathrm{H}_{5}^{+}$ & $3.688 \mathrm{e}-12$ & $1.241 \mathrm{e}-14$ \\
\hline $\mathrm{C}_{2} \mathrm{H}_{5} \mathrm{O}^{+}$ & $9.823 \mathrm{e}-13$ & $1.403 \mathrm{e}-12$ & $\mathrm{H}_{5} \mathrm{C}_{2} \mathrm{O}^{+}$ & $5.249 \mathrm{e}-14$ & $3.618 \mathrm{e}-18$ & $\mathrm{H}_{4} \mathrm{C}_{3} \mathrm{~N}^{+}$ & $1.021 \mathrm{e}-13$ & $1.135 \mathrm{e}-17$ \\
\hline $\mathrm{COOCH}_{4}^{+}$ & $1.040 \mathrm{e}-14$ & $3.116 \mathrm{e}-19$ & $\mathrm{C}_{5} \mathrm{H}_{3}^{+}$ & $2.892 \mathrm{e}-12$ & $4.345 \mathrm{e}-14$ & $\mathrm{H}_{3} \mathrm{C}_{4} \mathrm{~N}^{+}$ & $1.197 \mathrm{e}-18$ & $8.507 \mathrm{e}-21$ \\
\hline $\mathrm{C}_{6} \mathrm{H}_{2}^{+}$ & $2.083 \mathrm{e}-11$ & $1.161 \mathrm{e}-14$ & $\mathrm{H}_{2} \mathrm{C}_{5} \mathrm{~N}^{+}$ & $3.481 \mathrm{e}-12$ & $1.655 \mathrm{e}-15$ & $\mathrm{C}_{7} \mathrm{H}^{+}$ & $2.635 \mathrm{e}-12$ & $8.220 \mathrm{e}-16$ \\
\hline $\mathrm{C}_{8}^{+}$ & $1.316 \mathrm{e}-13$ & $1.167 \mathrm{e}-17$ & $\mathrm{C}_{7} \mathrm{~N}^{+}$ & $2.258 \mathrm{e}-18$ & $1.987 \mathrm{e}-23$ & $\mathrm{C}_{2} \mathrm{H}_{7}^{+}$ & $5.625 \mathrm{e}-24$ & $2.977 \mathrm{e}-24$ \\
\hline $\mathrm{C}_{2} \mathrm{H}_{5} \mathrm{OH}^{+}$ & $6.301 \mathrm{e}-16$ & $4.016 \mathrm{e}-18$ & $\mathrm{C}_{2} \mathrm{H}_{6} \mathrm{O}^{+}$ & $9.080 \mathrm{e}-13$ & $1.356 \mathrm{e}-17$ & $\mathrm{C}_{4} \mathrm{H}_{5}^{+}$ & $4.711 \mathrm{e}-13$ & $3.534 \mathrm{e}-16$ \\
\hline $\mathrm{H}_{5} \mathrm{C}_{2} \mathrm{O}_{2}^{+}$ & $6.440 \mathrm{e}-14$ & $6.368 \mathrm{e}-18$ & $\mathrm{C}_{5} \mathrm{H}_{4}^{+}$ & $2.235 \mathrm{e}-12$ & $9.805 \mathrm{e}-16$ & $\mathrm{H}_{4} \mathrm{C}_{4} \mathrm{~N}^{+}$ & $9.848 \mathrm{e}-13$ & $1.084 \mathrm{e}-16$ \\
\hline
\end{tabular}


Table 5. continued

\begin{tabular}{lllllllll}
\hline Species & Early time & Steady state & Species & Early time & Steady state & Species & Early time & Steady state \\
\hline $\mathrm{C}_{6} \mathrm{H}_{3}^{+}$ & $1.274 \mathrm{e}-12$ & $3.407 \mathrm{e}-15$ & $\mathrm{H}_{3} \mathrm{C}_{5} \mathrm{~N}^{+}$ & $8.009 \mathrm{e}-14$ & $7.655 \mathrm{e}-19$ & $\mathrm{C}_{7} \mathrm{H}_{2}^{+}$ & $6.734 \mathrm{e}-12$ & $2.375 \mathrm{e}-15$ \\
$\mathrm{C}_{8} \mathrm{H}^{+}$ & $7.079 \mathrm{e}-16$ & $7.630 \mathrm{e}-20$ & $\mathrm{HC}_{7} \mathrm{~N}^{+}$ & $3.911 \mathrm{e}-15$ & $7.367 \mathrm{e}-19$ & $\mathrm{C}_{9}^{+}$ & $6.425 \mathrm{e}-15$ & $2.188 \mathrm{e}-19$ \\
$\mathrm{C}_{2} \mathrm{H}_{6} \mathrm{OH}$ & $\mathrm{OH}^{+}$ & $8.073 \mathrm{e}-12$ & $2.981 \mathrm{e}-16$ & $\mathrm{C}_{2} \mathrm{H}_{7} \mathrm{O}^{+}$ & $1.087 \mathrm{e}-14$ & $1.655 \mathrm{e}-16$ & $\mathrm{C}_{2} \mathrm{H}_{6} \mathrm{CO}^{+}$ & $5.486 \mathrm{e}-17$ \\
$\mathrm{C}_{5} \mathrm{H}_{5}^{+}$ & $5.572 \mathrm{e}-12$ & $1.922 \mathrm{e}-15$ & $\mathrm{C}_{6} \mathrm{H}_{4}^{+}$ & $3.058 \mathrm{e}-13$ & $1.739 \mathrm{e}-15$ & $\mathrm{C}_{7} \mathrm{H}_{3}^{+}$ & $3.965 \mathrm{e}-13$ & $1.4340 \mathrm{e}-19$ \\
$\mathrm{C}_{8} \mathrm{H}_{2}^{+}$ & $5.335 \mathrm{e}-12$ & $8.817 \mathrm{e}-16$ & $\mathrm{H}_{2} \mathrm{C}_{7} \mathrm{~N}^{+}$ & $2.750 \mathrm{e}-13$ & $4.765 \mathrm{e}-17$ & $\mathrm{C}_{9} \mathrm{H}^{+}$ & $1.047 \mathrm{e}-12$ & $4.157 \mathrm{e}-17$ \\
$\mathrm{C}_{10}^{+}$ & $4.670 \mathrm{e}-13$ & $3.256 \mathrm{e}-18$ & $\mathrm{C}_{9} \mathrm{~N}^{+}$ & $8.971 \mathrm{e}-19$ & $1.005 \mathrm{e}-24$ & $\mathrm{C}_{3} \mathrm{H}_{6} \mathrm{OH}^{+}$ & $4.695 \mathrm{e}-16$ & $7.619 \mathrm{e}-18$ \\
$\mathrm{C}_{6} \mathrm{H}_{5}^{+}$ & $3.793 \mathrm{e}-13$ & $2.386 \mathrm{e}-17$ & $\mathrm{C}_{7} \mathrm{H}_{4}^{+}$ & $1.747 \mathrm{e}-13$ & $5.583 \mathrm{e}-18$ & $\mathrm{H}_{4} \mathrm{C}_{6} \mathrm{~N}^{+}$ & $3.466 \mathrm{e}-14$ & $1.216 \mathrm{e}-19$ \\
$\mathrm{C}_{8} \mathrm{H}_{3}^{+}$ & $1.053 \mathrm{e}-13$ & $2.995 \mathrm{e}-17$ & $\mathrm{H}_{3} \mathrm{C}_{7} \mathrm{~N}^{+}$ & $4.620 \mathrm{e}-13$ & $2.710 \mathrm{e}-17$ & $\mathrm{C}_{9} \mathrm{H}_{2}^{+}$ & $8.292 \mathrm{e}-13$ & $2.493 \mathrm{e}-17$ \\
$\mathrm{HC}_{9} \mathrm{~N}^{+}$ & $5.872 \mathrm{e}-16$ & $2.679 \mathrm{e}-21$ & $\mathrm{C}_{7} \mathrm{H}_{5}^{+}$ & $4.788 \mathrm{e}-13$ & $1.190 \mathrm{e}-17$ & $\mathrm{C}_{8} \mathrm{H}_{4}^{+}$ & $2.203 \mathrm{e}-13$ & $8.548 \mathrm{e}-18$ \\
$\mathrm{C}_{9} \mathrm{H}_{3}^{+}$ & $1.543 \mathrm{e}-13$ & $1.487 \mathrm{e}-17$ & $\mathrm{H}_{2} \mathrm{C}_{9} \mathrm{~N}^{+}$ & $3.082 \mathrm{e}-14$ & $1.634 \mathrm{e}-19$ & $\mathrm{C}_{8} \mathrm{H}_{5}^{+}$ & $1.531 \mathrm{e}-19$ & $3.177 \mathrm{e}-21$ \\
$\mathrm{C}_{9} \mathrm{H}_{4}^{+}$ & $1.645 \mathrm{e}-13$ & $8.081 \mathrm{e}-19$ & $\mathrm{H}_{4} \mathrm{C}_{8} \mathrm{~N}^{+}$ & $1.576 \mathrm{e}-14$ & $1.819 \mathrm{e}-20$ & $\mathrm{H}_{3} \mathrm{C}_{9} \mathrm{~N}^{+}$ & $1.846 \mathrm{e}-14$ & $6.975 \mathrm{e}-20$ \\
$\mathrm{C}_{9} \mathrm{H}_{5}^{+}$ & $7.636 \mathrm{e}-19$ & $8.565 \mathrm{e}-21$ & $\mathrm{e}^{-}$ & $4.571 \mathrm{e}-8$ & $4.375 \mathrm{e}-8$ & & \\
\hline
\end{tabular}

$\mathrm{O}_{2}+\mathrm{H}$ reaction. The $\mathrm{O}_{2}$ abundance is unchanged by this change to the rate coefficient because the 'throughput', which depends on the product $k n(\mathrm{O}) n(\mathrm{OH})$ is unchanged. This can only occur when the reaction is the major route to formation. At steady state the reaction contributes $83 \%$ to the loss rate of $\mathrm{OH}$.

The increased $\mathrm{C}$ and $\mathrm{NO}$ abundances have a minor effect on the abundance of $\mathrm{CN}$ since they form this molecule at the $30 \%$ level. The major route to $\mathrm{CN}$ is the dissociative recombination of $\mathrm{HCNH}^{+}$with electrons, although the branching ratio to $\mathrm{CN}$ (and those to HCN and HNC) are only estimated theoretically. An experimental determination of these ratios is needed. The rate of formation of $\mathrm{CN}$ is increased by about a factor of 1.5 but the $\mathrm{CN}$ abundance falls by about 30 because the reaction $\mathrm{CN}+$ $\mathrm{O}_{2} \rightarrow \mathrm{CO}+\mathrm{NO}$ is about 70 times faster in RATE95 than in RATE90. This reaction has, through altering the abundance of $\mathrm{CN}$, an affect on the abundance of other species. Note that the $\mathrm{CN}+\mathrm{O}_{2}$ reaction rate coefficient has been measured down to $13 \mathrm{~K}$.

The increased abundances of $\mathrm{NO}$ and $\mathrm{OH}$ also cause the $\mathrm{N}$ atom abundance to decrease by about 40 because the reactions of $\mathrm{N}$ with $\mathrm{NO}$ and $\mathrm{OH}$ are very efficient at converting atomic nitrogen into nitrogen-bearing molecules.

Other molecules, particularly oxides, are affected by the increased $\mathrm{OH}$ abundance. They include $\mathrm{CO}_{2}$, which is a factor of 10 larger, and which is formed by the $\mathrm{CO}+$ $\mathrm{OH}$ reaction. $\mathrm{CO}_{2}$ is unobservable from the ground, except indirectly via its protonated form, $\mathrm{HOCO}^{+}$, but should be detectable at IR wavelengths by the $I S O$ mission. The only phosphorus molecule yet detected in interstellar clouds, $\mathrm{PN}$, decreases by an order of magnitude due to the indirect effects of $\mathrm{OH}$.

The uncertainty attached to the calculated abundance of OCN in this model calculation is difficult to quantify as it is uncertain how this species forms in interstellar clouds. In the ratefile, it is formed in the reaction of $\mathrm{CN}$ with $\mathrm{O}_{2}$, which is less efficient due to the decrease in the $\mathrm{CN}$ abundance. The OCN abundance is a factor of 20 lower in this model.

Finally, the abundance of HPO decreases by about 30 due to the inclusion of the reaction $\mathrm{O}+\mathrm{HPO} \rightarrow \mathrm{PO}+$ $\mathrm{OH}$, which was not included in RATE90.

\subsection{Carbon-chain species}

The $\mathrm{C}_{2} \mathrm{H}$ abundance is a factor of around 100 less because of more rapid loss with $\mathrm{O}$ and $\mathrm{O}_{2}$. These reactions, which were assumed to have activation energy barriers of $250 \mathrm{~K}$ and $3500 \mathrm{~K}$, respectively, are now taken to be activationless. The $\mathrm{C}_{4} \mathrm{H}_{2}$ molecule, which in RATE90 was produced primarily by the $\mathrm{C}_{2} \mathrm{H}+\mathrm{C}_{2} \mathrm{H}_{2} \rightarrow \mathrm{C}_{4} \mathrm{H}_{2}+\mathrm{H}$ reaction, falls by an order of magnitude as the $\mathrm{C}_{2} \mathrm{H}$ abundance is lower. $\mathrm{HC}_{3} \mathrm{~N}$ also falls by an order of magnitude. Although the formation reaction $\mathrm{CN}+\mathrm{C}_{2} \mathrm{H}_{2} \rightarrow \mathrm{HC}_{3} \mathrm{~N}+\mathrm{H}$ has a larger rate coefficient in RATE95, the decrease in the CN abundance by a factor of 30 more than offsets this. The $\mathrm{C}_{5}$ abundance falls by $\sim 10^{3}$ due to the inclusion of a new rapid destruction channel, reaction with $\mathrm{O}$ atoms, which dominates over the loss reactions of $\mathrm{C}_{5}$ with ions. However, since the products of this reaction are assumed to be $\mathrm{C}_{4}$ and $\mathrm{CO}$, the $\mathrm{C}_{4}$ abundance increases by $\sim 200$. Rapid destruction of $\mathrm{C}_{4}$ with $\mathrm{O}$ atoms is included in both RATE90 and RATE95.

The formation of $\mathrm{CH}_{3} \mathrm{CHO}$ increases by around 100 due to a large increase in the rate coefficient of the radiative association $\mathrm{H}_{3} \mathrm{O}^{+}+\mathrm{C}_{2} \mathrm{H}_{2} \rightarrow \mathrm{C}_{2} \mathrm{H}_{5} \mathrm{O}^{+}+\mathrm{h} \nu$, from which $\mathrm{CH}_{3} \mathrm{CHO}$ forms by dissociative recombination.

The heavy molecule $\mathrm{CH}_{3} \mathrm{C}_{3} \mathrm{~N}$ decreases in abundance by $\sim 1000$ due to the inclusion of an additional channel in the products of the dissociative recombination of $\mathrm{H}_{4} \mathrm{C}_{4} \mathrm{~N}^{+}$, protonated $\mathrm{CH}_{3} \mathrm{C}_{3} \mathrm{~N}$. In RATE90, the only products of the recombination are $\mathrm{CH}_{3} \mathrm{C}_{3} \mathrm{~N}+\mathrm{H}$. Thus, proton transfer, followed by dissociative recombination, simply recycles the neutral molecule and its effective destruction is small. In RATE95, we include, with an equal branching ratio, a channel to $\mathrm{CH}_{3}+\mathrm{HC}_{3} \mathrm{~N}$, which breaks the recycling 
process and leads to a much larger destruction rate for $\mathrm{CH}_{3} \mathrm{C}_{3} \mathrm{~N}$.

Because the results of the calculation shown in Table 5 are for physical parameters similar to those in the dark dust cloud TMC-1, we show in Table 6 a comparison between the calculated abundances at early time $\left(3.1610^{5} \mathrm{yr}\right)$ and steady-state $\left(10^{8} \mathrm{yr}\right)$ and those observed toward TMC-1. This calculation has not been optimised in the sense of searching for the best-fit through looking for the best time, varying elemental abundances, cosmic ray ionisation rate, etc., but it does show that the chemistry is particularly suited to this type of source. In general, around one-half of the molecules agree to within a factor of 5 at early time, although there are some notable exceptions. $\mathrm{SO}$ and $\mathrm{SO}_{2}$ both increase in abundance rapidly at late times and agree with the observations around steadystate, although the $\mathrm{SO}_{2}$ abundance is too large at this time. Some molecules, $\mathrm{C}_{n} \mathrm{H}(n=3-6)$ for example, are much too large at early time. This may indicate that they have faster loss reactions with $\mathrm{O}$ atoms than adopted in the rate file, where we have assumed an activation energy barrier of $250 \mathrm{~K} . \mathrm{H}_{2} \mathrm{~S}$ is too low at all times and this might indicate that the radiative association rate coefficient for the $\mathrm{S}^{+}-\mathrm{H}_{2}$ reaction has been underestimated (see Millar $\&$ Herbst 1990 for a discussion). The abundances of $\mathrm{HCS}^{+}$ and $\mathrm{HCNH}^{+}$are roughly an order of magnitude below the observations. This difference can be resolved by the adoption of ion-dipolar rate coefficients for the proton transfer reactions of CS and HCN. Finally, we note that contrary to many statements in the literature, the $\mathrm{NH}_{3}$ abundance agrees with the observations at early times and does not need a special chemistry to be invoked.

\section{On-line access to the database}

The database is up-dated on a regular, usually annual, basis. The current version is kept on-line and can be accessed via the World Wide Web at URL http://saturn.phy.umist.ac.uk:8000/ tjm/rate/rate.html, which contains a short article describing the data and links to the files containing the species set (Table 2), the dipole moments (Table 3 ), the heats of formation (Table 2) and the rate coefficients (Table 4). A link can also be found here to a FORTRAN program, DELOAD, originally written by Dr. L.A.M. Nejad, which reads the species set and reaction file and writes output in the form of a FORTRAN subroutine.

Keeping a database such as this up-to-date is a difficult and time-consuming task. Any additions, corrections, suggestions for improvement or other comments on this database will be gratefully received by T.J. Millar (e-mail address: tjm@ast.phy.umist.ac.uk).

Acknowledgements. The work of PRAF and KW is supported via a grant from the Particle Physics and Astronomy Research Council (PPARC).

\section{References}

Adams N.G., 1992, Adv. Gas Phase Ion Chem. 1, 271 Adams N.G., Giles K., Smith D., 1992 (unpublished) Adams N.G., et al., 1991, J. Chem. Phys. 94, 4852

Adams N.G., MacIntosh B.J., Smith D., 1990, A\&A 232, 443

Adams N.G., Smith D., 1987, in Astrochemistry, Vardya M.S. and Tarafdar S.P. (eds.). Reidel, Dordrecht, p. 1

Adams N.G., Smith D., Clary D.C., 1985, ApJ 296, L31

Adams N.G., Smith D., Millar T.J., 1984, MNRAS 211, 857

Alge E., Adams N.G., Smith D., 1983, J. Phys. B 16, 1433

Altwegg K., Balsiger H., Geiss J., 1994, A\&A 290, 318

Amano T., 1990, J. Phys. Chem. 92, 6492

Anicich V.G., 1993, ApJS 84, 215

Anicich V.G., Huntress W.T.Jr., 1986, ApJS 62, 553

Baulch D.L., et al., 1992, J. Phys. Chem. Ref. Data 21, 411

Barlow S.G., 1984, PhD Thesis, University of Colorado

Becker R.S., Hong J.H., 1983, J. Phys. Chem. 87, 163

Bettens R.P.A., Lee H.-H., Herbst E., 1995, ApJ 443, 664

Bergin E.A., Langer W.D., Goldsmith P.F., 1995, ApJ 441, 222

Bohme D.K., 1990, Int. J. Mass Spectrom. Ion Proc. 100, 719

Bohme D.K., Wlodek S., Raksit A.B., 1987, Can. J. Chem. 65, 1563

Boissé P., 1991, A\&A 228, 483

Botschwina P., Flugge J., Sebald P., 1995, J. Phys. Chem. 99, 9755

Botschwina P., et al., 1994, in Molecules and Grains in Space, Nenner I. (ed.). AIP Press, New York

Botschwina P., Oswald R., Flugge J., Horn M., 1995, Z. Phys. Chem. 188, 29

Canosa A., Rowe B.R., Mitchell J.B.A., Gomet J.C., Rebrion C., 1991, A\&A 248, L19

Charnley S.B., Kress M.E., Tielens A.G.G.M., Millar T.J., 1995, ApJ 448, 232

Charnley S.B., Millar T.J., 1994, MNRAS 270, 570

Charnley S.B., Tielens A.G.G.M., Millar T.J., 1992, ApJ 399, L71

Cherchneff I., Glassgold A.E., 1993, ApJ 419, L41

Cherchneff I., Glassgold A.E., Mamon G.A., 1993, ApJ 410, 188

Clary D.C., Haider N., Husain D., Kabar M., 1994, ApJ 422, 416

Dalgarno A., Du M.L., You J.H., 1990, ApJ 349, 675

Dheandanoo S., Forte L., Fox A., Bohme D.K., 1986, Can. J. Chem. 64, 641

Dove J.E., Mandy M.E., 1986, ApJ 311, L93

Draine B.T., 1978, ApJS 36, 595

Eberhardt P., Krankowsky D., 1995, A\&A 295, 795

Eberhardt P., Meier R., Krankowsky D., Hodges R.R., 1994, A\&A 288, 315

Farquhar P.R.A., Millar T.J., 1993, CCP7 Newslett. 18, 6

Federer W., Villinger H., Lindinger W., Richter R., Ferguson E.E., 1986, Chem. Phys. Letts. 123, 12

Frost M.J., Sharkey P., Smith I.W.M., 1991, J. Chem. Soc. Faraday Trans. 91, 305

Gerlich D., Horning S., 1992, Chem. Rev. 92, 1509

Giles K., 1990, PhD Thesis, University of Birmingham

Giles K., Adams N.G., Smith D., 1989, Int. J. Mass Spectrom. Ion Proc. 89, 303

Gingerich K.A., Finkbeiner H.C., Schmude R.W., 1994, JACS 116, 3884 
Table 6. Comparison of observations toward TMC-1 (Ohishi et al. 1992) with fractional abundances with respect to $\mathrm{H}_{2}$ at $3.1610^{5}$ (early time) and $10^{8}$ (steady state) years

\begin{tabular}{|c|c|c|c|c|c|c|c|}
\hline$\overline{\text { Species }}$ & Early time & Steady state & Observed & Species & Early time & Steady state & Observed \\
\hline$\overline{\mathrm{C}}$ & $1.3 \mathrm{e}-05$ & $1.8 \mathrm{e}-09$ & $1.0 \mathrm{e}-04$ & $\mathrm{CH}$ & $1.3 \mathrm{e}-08$ & $2.9 \mathrm{e}-10$ & $2.0 \mathrm{e}-08$ \\
\hline $\mathrm{C}_{2}$ & $1.0 \mathrm{e}-08$ & $3.3 e-10$ & $5.0 \mathrm{e}-08$ & $\mathrm{CN}$ & $8.3 \mathrm{e}-08$ & $1.0 \mathrm{e}-10$ & $3.0 \mathrm{e}-08$ \\
\hline $\mathrm{CO}$ & $1.1 \mathrm{e}-04$ & $1.4 \mathrm{e}-04$ & $8.0 \mathrm{e}-05$ & CS & $3.3 \mathrm{e}-08$ & $2.7 \mathrm{e}-09$ & $1.0 \mathrm{e}-08$ \\
\hline $\mathrm{OH}$ & $2.1 \mathrm{e}-07$ & $9.6 \mathrm{e}-07$ & $3.0 \mathrm{e}-07$ & $\mathrm{NO}$ & $2.2 \mathrm{e}-07$ & $3.3 e-06$ & $<3.0 \mathrm{e}-08$ \\
\hline $\mathrm{SO}$ & $3.3 \mathrm{e}-11$ & $5.2 \mathrm{e}-09$ & $5.0 \mathrm{e}-09$ & $\mathrm{C}_{2} \mathrm{H}$ & $2.7 \mathrm{e}-09$ & $9.2 \mathrm{e}-12$ & $5.0 \mathrm{e}-08$ \\
\hline $\mathrm{CCO}$ & $1.9 \mathrm{e}-10$ & $1.6 \mathrm{e}-11$ & $6.0 \mathrm{e}-10$ & $\mathrm{C}_{2} \mathrm{~S}$ & $1.3 \mathrm{e}-09$ & $5.5 e-11$ & $8.0 \mathrm{e}-09$ \\
\hline $\mathrm{HCN}$ & $6.8 \mathrm{e}-08$ & $4.0 \mathrm{e}-09$ & $2.0 \mathrm{e}-08$ & $\mathrm{HNC}$ & $3.3 e-08$ & $6.8 \mathrm{e}-09$ & $2.0 \mathrm{e}-08$ \\
\hline OCS & $5.2 \mathrm{e}-11$ & $3.7 \mathrm{e}-11$ & $2.0 \mathrm{e}-09$ & $\mathrm{H}_{2} \mathrm{~S}$ & $4.4 \mathrm{e}-12$ & $2.9 \mathrm{e}-11$ & $<5.0 \mathrm{e}-10$ \\
\hline $\mathrm{SO}_{2}$ & $8.1 \mathrm{e}-12$ & $3.0 \mathrm{e}-08$ & $<1.0 \mathrm{e}-09$ & $\mathrm{C}_{3} \mathrm{H}$ & $1.1 \mathrm{e}-06$ & $2.2 \mathrm{e}-09$ & $1.1 \mathrm{e}-09$ \\
\hline $\mathrm{C}_{3} \mathrm{~N}$ & $3.0 \mathrm{e}-08$ & $9.4 \mathrm{e}-12$ & $1.0 \mathrm{e}-09$ & $\mathrm{C}_{3} \mathrm{O}$ & $1.6 \mathrm{e}-10$ & $1.3 \mathrm{e}-10$ & $1.0 \mathrm{e}-10$ \\
\hline $\mathrm{C}_{3} \mathrm{~S}$ & $5.5 \mathrm{e}-10$ & $8.6 \mathrm{e}-12$ & $1.0 \mathrm{e}-09$ & $\mathrm{H}_{2} \mathrm{CO}$ & $9.9 \mathrm{e}-07$ & $1.4 \mathrm{e}-08$ & $2.0 \mathrm{e}-08$ \\
\hline $\mathrm{H}_{2} \mathrm{CS}$ & $9.8 \mathrm{e}-10$ & $1.8 \mathrm{e}-11$ & $3.0 \mathrm{e}-09$ & $\mathrm{NH}_{3}$ & $4.9 \mathrm{e}-08$ & $1.4 \mathrm{e}-07$ & $2.0 \mathrm{e}-08$ \\
\hline $\mathrm{C}_{4} \mathrm{H}$ & $8.6 \mathrm{e}-07$ & 7.1e-09 & $2.0 \mathrm{e}-08$ & $\mathrm{C}_{3} \mathrm{H}_{2}$ & $9.6 \mathrm{e}-09$ & $5.7 \mathrm{e}-09$ & $1.0 \mathrm{e}-08$ \\
\hline $\mathrm{HC}_{3} \mathrm{~N}$ & $3.8 \mathrm{e}-08$ & $1.7 \mathrm{e}-10$ & $6.0 \mathrm{e}-09$ & $\mathrm{CH}_{2} \mathrm{CN}$ & $5.2 \mathrm{e}-08$ & $7.5 \mathrm{e}-11$ & $5.0 \mathrm{e}-09$ \\
\hline $\mathrm{CH}_{2} \mathrm{CO}$ & $1.0 \mathrm{e}-07$ & $4.0 \mathrm{e}-10$ & $1.0 \mathrm{e}-09$ & $\mathrm{CHOOH}$ & $2.6 \mathrm{e}-08$ & $2.6 \mathrm{e}-08$ & $<2.0 \mathrm{e}-10$ \\
\hline $\mathrm{C}_{5} \mathrm{H}$ & $2.4 \mathrm{e}-08$ & $4.0 \mathrm{e}-11$ & $3.0 \mathrm{e}-10$ & $\mathrm{C}_{4} \mathrm{H}_{2}$ & $4.0 \mathrm{e}-11$ & $2.9 \mathrm{e}-11$ & $8.0 \mathrm{e}-10$ \\
\hline $\mathrm{CH}_{3} \mathrm{CN}$ & $1.9 \mathrm{e}-08$ & $8.9 \mathrm{e}-12$ & $1.0 \mathrm{e}-09$ & $\mathrm{CH}_{3} \mathrm{OH}$ & $1.5 \mathrm{e}-07$ & $7.0 \mathrm{e}-10$ & $2.0 \mathrm{e}-09$ \\
\hline $\mathrm{C}_{6} \mathrm{H}$ & $1.5 \mathrm{e}-07$ & $4.5 \mathrm{e}-11$ & $1.0 \mathrm{e}-10$ & $\mathrm{HC}_{5} \mathrm{~N}$ & $1.4 \mathrm{e}-09$ & $4.4 \mathrm{e}-13$ & $3.0 \mathrm{e}-09$ \\
\hline $\mathrm{C}_{3} \mathrm{H}_{4}$ & $2.9 \mathrm{e}-11$ & $8.8 \mathrm{e}-12$ & $6.0 \mathrm{e}-09$ & $\mathrm{H}_{3} \mathrm{C}_{3} \mathrm{~N}$ & $1.3 \mathrm{e}-10$ & $1.0 \mathrm{e}-14$ & $2.0 \mathrm{e}-10$ \\
\hline $\mathrm{CH}_{3} \mathrm{CHO}$ & $2.6 \mathrm{e}-10$ & $4.0 \mathrm{e}-10$ & $6.0 \mathrm{e}-10$ & $\mathrm{H}_{3} \mathrm{C}_{4} \mathrm{~N}$ & $3.7 \mathrm{e}-10$ & $3.8 \mathrm{e}-14$ & $5.0 \mathrm{e}-10$ \\
\hline $\mathrm{HC}_{7} \mathrm{~N}$ & $7.1 \mathrm{e}-10$ & $6.7 \mathrm{e}-14$ & $1.0 \mathrm{e}-09$ & $\mathrm{C}_{5} \mathrm{H}_{4}$ & $4.8 \mathrm{e}-11$ & $2.4 \mathrm{e}-12$ & $2.0 \mathrm{e}-10$ \\
\hline $\mathrm{HC}_{9} \mathrm{~N}$ & $6.3 e-11$ & $2.1 \mathrm{e}-16$ & $3.0 \mathrm{e}-10$ & $\mathrm{HCO}^{+}$ & $7.0 \mathrm{e}-09$ & $1.3 \mathrm{e}-08$ & $8.0 \mathrm{e}-09$ \\
\hline $\mathrm{HCS}^{+}$ & $3.1 \mathrm{e}-11$ & $4.0 \mathrm{e}-12$ & $6.0 \mathrm{e}-10$ & $\mathrm{~N}_{2} \mathrm{H}^{+}$ & $4.9 \mathrm{e}-10$ & $8.9 \mathrm{e}-10$ & $5.0 \mathrm{e}-10$ \\
\hline $\mathrm{HCNH}^{+}$ & $1.1 \mathrm{e}-10$ & $1.5 \mathrm{e}-11$ & $1.9 \mathrm{e}-09$ & & & & \\
\hline
\end{tabular}

Gredel R., Lepp S., Dalgarno A., 1987, ApJ 323, L137

Gredel R., Lepp S., Dalgarno A., Herbst E., 1989, ApJ 347, 289

Haider N., Husain D., 1993a, J. Photochem. Photobiol. A70, 119

Haider N., Husain D., 1993b, J. Chem. Soc. Faraday Trans. 89, 7

Hasegawa T.I., Herbst E., 1993, MNRAS 261, 83

Herbst E., 1985, ApJ 291, 226

Herbst E., 1987, ApJ 313, 867

Herbst E., Adams N.G., Smith D., Giles K., 1989a, J. Chem. Soc. Far. Trans. 85, 1655

Herbst E., DeFrees D.J., Koch W., 1989b, MNRAS 237, 1057

Herbst E., Giles K., Smith D., 1990, ApJ 358, 468

Herbst E., Lee H.-H., Howe D.A., Millar T.J., 1994, MNRAS 268,335

Herbst E., Leung C.M., 1986, ApJ 310, 378

Herbst E., Leung C.M., 1989, ApJS 69, 271

Herbst E., Leung C.M., 1990, A\&A 233, 177

Herbst E., Millar T.J., Wlodek S., Bohme D.K., 1989, A\&A 222,205

Herd C.R., Adams N.G., Smith D., 1990, ApJ 349, 388

Hollenbach D.J., Salpeter E.E., 1972, J. Chem. Phys. 53, 79

Husain D., Norris P.E., 1979, Far. Disc. Chem. Soc. 67, 273

Jura M., 1975a, ApJ 197, 575

Jura M., 1975b, ApJ 197, 581

Karpas Z., Meot-ner M., 1989, J. Phys, Chem. 93, 1859

Kimura M., Dalgarno A., 1993, Chem. Phys. Letts. 211, 454
Lee H.-H., Herbst E., Pineau des Forêts G.P., Roueff E., Le Bourlot J., 1996, A\&A (in press)

Leen T.M., Graff M.M., 1988, ApJ 325, 411

Leung C.M., Herbst E., Huebner W.F., 1984, ApJS 56, 231

MacKay D.D.S., 1995, MNRAS 274, 694

MacKay D.D.S., 1996, MNRAS 278, 62

Mallard W.G., Westley F., Herron J.T., Hampson R.F., Frizell D.H., 1994, NIST Chemical Kinetics Database: Ver. 6.0, National Institute of Standards and Technology, Gaithersburg, MD

Maluendes S., McLean A.D., Herbst E., 1993, ApJ 417, 181

Marston G., Nesbitt F.L., Stief L.J., 1989, J. Chem. Phys. 91, 3483

Meier R., Eberhardt P., Krankowsky D., Hodges R.R., 1993, A\&A 277,677

Meier R., Eberhardt P., Krankowsky D., Hodges R.R., 1994, A\&A 287, 268

Millar T.J., 1991, A\&A 242, 241

Millar T.J., Adams N.G., Smith D., Clary D.C., 1985, MNRAS 216, 1025

Millar T.J., Adams N.G., Smith D., Lindinger W., Villinger H., 1986, MNRAS 221, 673

Millar T.J., Bennett, A., Herbst, E., 1987, MNRAS 229, 41P

Millar T.J., Herbst E., 1990, A\&A 231, 466

Millar T.J., Herbst E., 1994, A\&A 288, 561

Millar T.J., Herbst E., Charnley S.B., 1991a, ApJ 369, 147

Millar T.J., Nejad L.A.M., 1985, MNRAS 217, 507

Millar T.J., Rawlings J.M.C., Bennett A., Brown P.D., Charnley S.B., 1991b, A\&AS 87, 585 
Mitchell G.F., 1984, ApJ 287, 665

Mitchell G.F., Deveau T.J., 1983, ApJ 266, 646

Mitchell J.B.A., 1990, Phys. Rep. 186, 215

Nesbitt F.L., Marston G., Stief L.J., 1990, J. Phys. Chem. 94, 4946

Neufeld D., Lepp S., Melnick G., 1995, ApJS 100, 132

Ohishi M., Irvine W.M., Kaifu N., 1992, in Astrochemistry of Cosmic Phenomena, Singh P.D. (ed.). Kluwer Academic Publishers, Dordrecht, p. 171

Ohishi M., et al., 1991, ApJ 380, L39

Oswald M., Botschwina P., 1995, J. Mol. Spectrosc. 169, 181

Petrie S., Freeman C.G., McEwan M.J., 1992, MNRAS 257, 438

Pineau des Forêts G., Roueff E., Flower D.R., 1990, MNRAS 244,668

Prasad S.S., Huntress W.T. Jr., 1980, ApJS 43, 1

Prasad S.S., Huntress W.T. Jr., 1982, ApJ 250, 590

Prasad S.S., Tarafdar S.P., 1983, ApJ 267, 603

Rawlings J.M.C., 1992 (private communication)

Rawlings J.M.C., Williams D.A., Canto J., 1988, MNRAS 230, 695

Roberge W.G., Dalgarno A., 1982, ApJ 255, 176

Roberge W.G., Jones D., Lepp S., Dalgarno A., 1991, ApJS 77,287

Rowe B.R., Mitchell J.B.A., Canosa A., 1993, Dissociative Recombination: Theory, Experiment, and Applications. Plenum Press, New York

Sen A., Anicich V.G., Federman S.R., 1992, ApJ 391, 141

Sims I.R., et al., 1992, J. Chem. Phys. 97, 8798

Sims I.R., et al., 1993b, J. Chem. Phys. 100, 4229

Sims I.R., et al., 1993a, Chem. Phys. Lett. 211, 461

Smith D., Adams N.G., 1984, ApJ 284, L13

Smith D., Adams N.G., Giles K., Herbst E., 1988, A\&A 200, 191
Smith D., MacIntosh B.J., Adams N.G., 1989, J. Chem. Phys. 90, 6213

Smith D., Spanel P., 1993, Chem. Phys. Letts. 211, 454

Smith D., Spanel P., Mayhew C.A., 1992, Int. J. Mass Spectrom. Ion Proc. 117, 457

Smith D., Spanel P., Millar T.J., 1994, MNRAS 266, 31

Smith I.W.M., 1989, ApJ 347, 282

Smith I.W.M., Sims I.R., 1993, J. Chem. Soc. Faraday Trans. 89,2166

Smith M.A., 1993, J. Chem. Soc. Farad. Trans. 89, 2210

Spaans M., Tielens A.G.G.M., Van Dishoeck E.F., Bakes E.L.O., 1995, A\&A 437, 270

Stief L.J., Marston G., Nava D.F., Payne W.A., Nesbitt F.L., 1988, Chem. Phys. Letts. 147, 570

Sternberg A., Dalgarno A., 1995, ApJS 99, 565

Suernam R.D., Lovas F.J., 1994, ApJ 429, L89

Sundstrom G., et al., 1994, Sci 263, 785

Suzuki H., Yamamoto S., Ohishi M., Kaifu N., Ishikawa S.-I., Hirahara Y., Takano S., 1992, ApJ 392, 551

Thorne L.R., Anicich V.G., Prasad S.S., Huntress W.T.Jr., 1984, ApJ 280, 139

Troe J., 1987, J. Chem. Phys. 87, 2773

Tsang W., Hampson R.F., 1986, J. Phys. Chem. Ref. Data 15, 1087

van Dishoeck E.F., 1987, in Astrochemistry, Vardya M.S. and Tarafdar S.P. (eds.). Reidel, Dordrecht, p. 51

van Dishoeck E.F., 1988, in Rate Coefficients in Astrochemistry, Millar T.J. and Williams D.A. (eds.). Kluwer Academic Publishers, Dordrecht, p. 49

van Dishoeck E.F., Black J.H., 1988, ApJ 334, 771

Warin S., Benayoun J.J., Viala Y.P., 1996, A\&A 308, 535

Wilson P.F., McEwan M.J., Meot-ner M., 1994, Int. J. Mass Spectrom. Ion Proc. 132, 149

Wlodek S., Bohme D.K., Herbst E., 1988, MNRAS 235, 493 
Table 4. Reactions and their rate coefficients

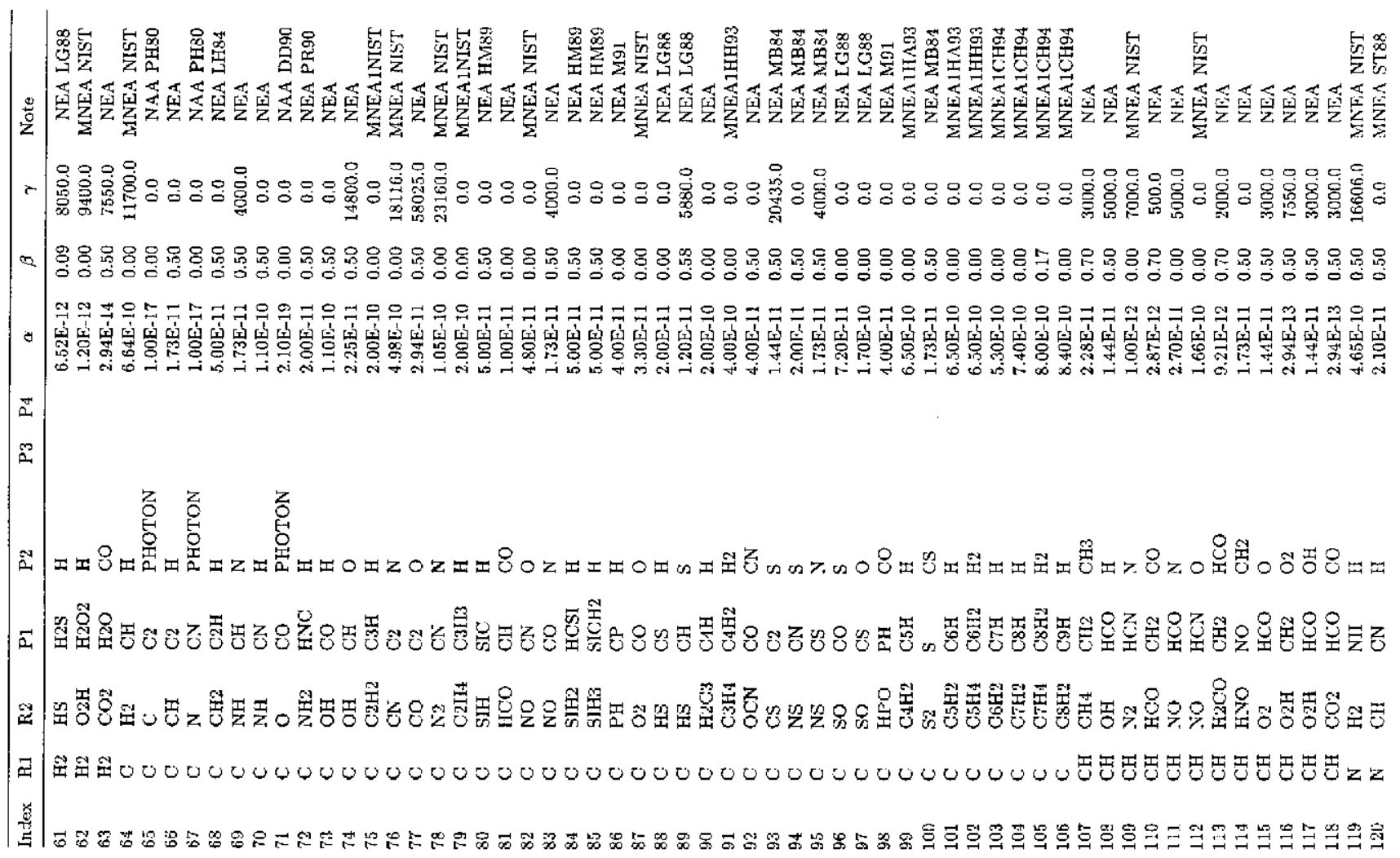

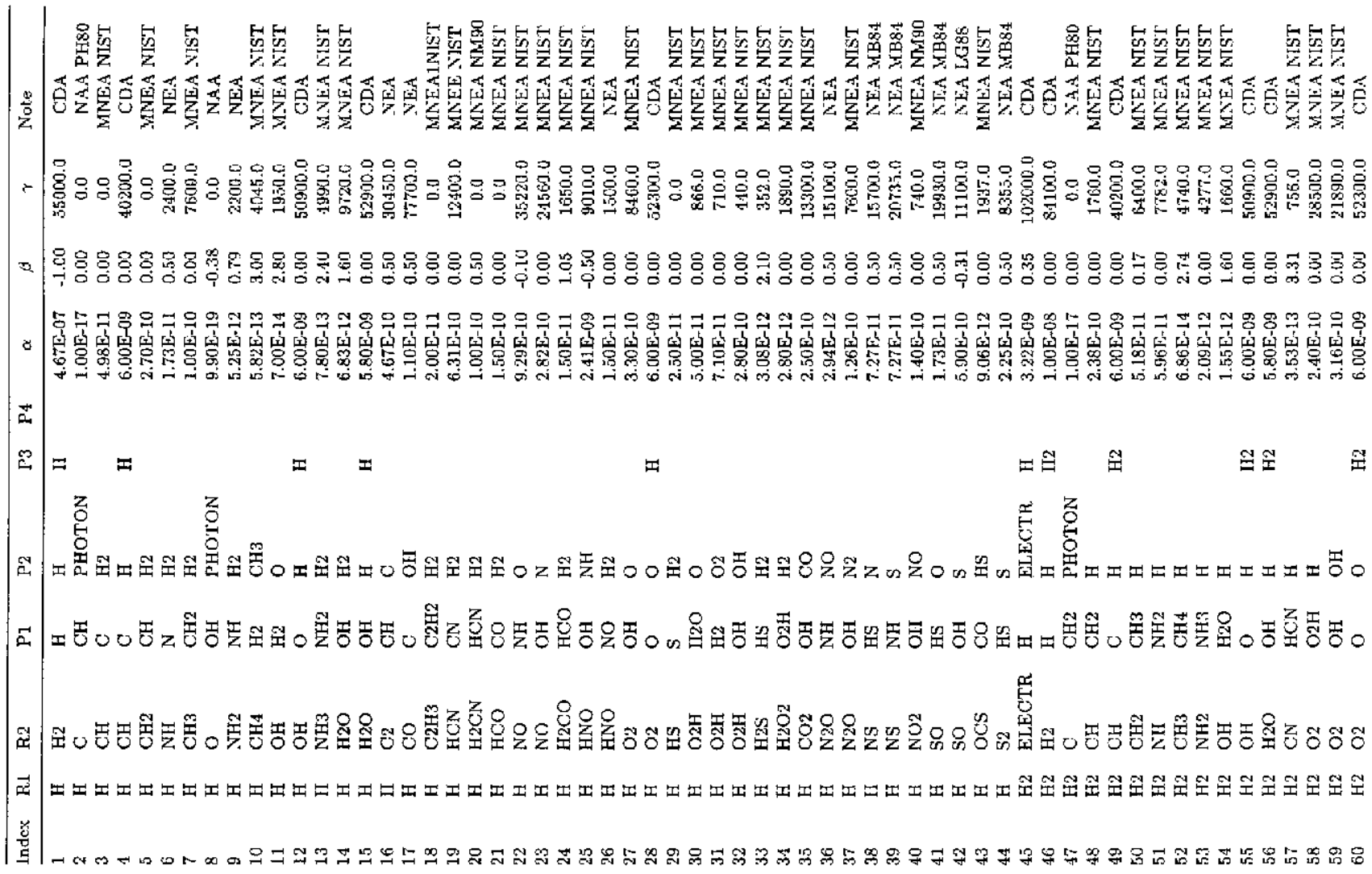


Table 4. continued
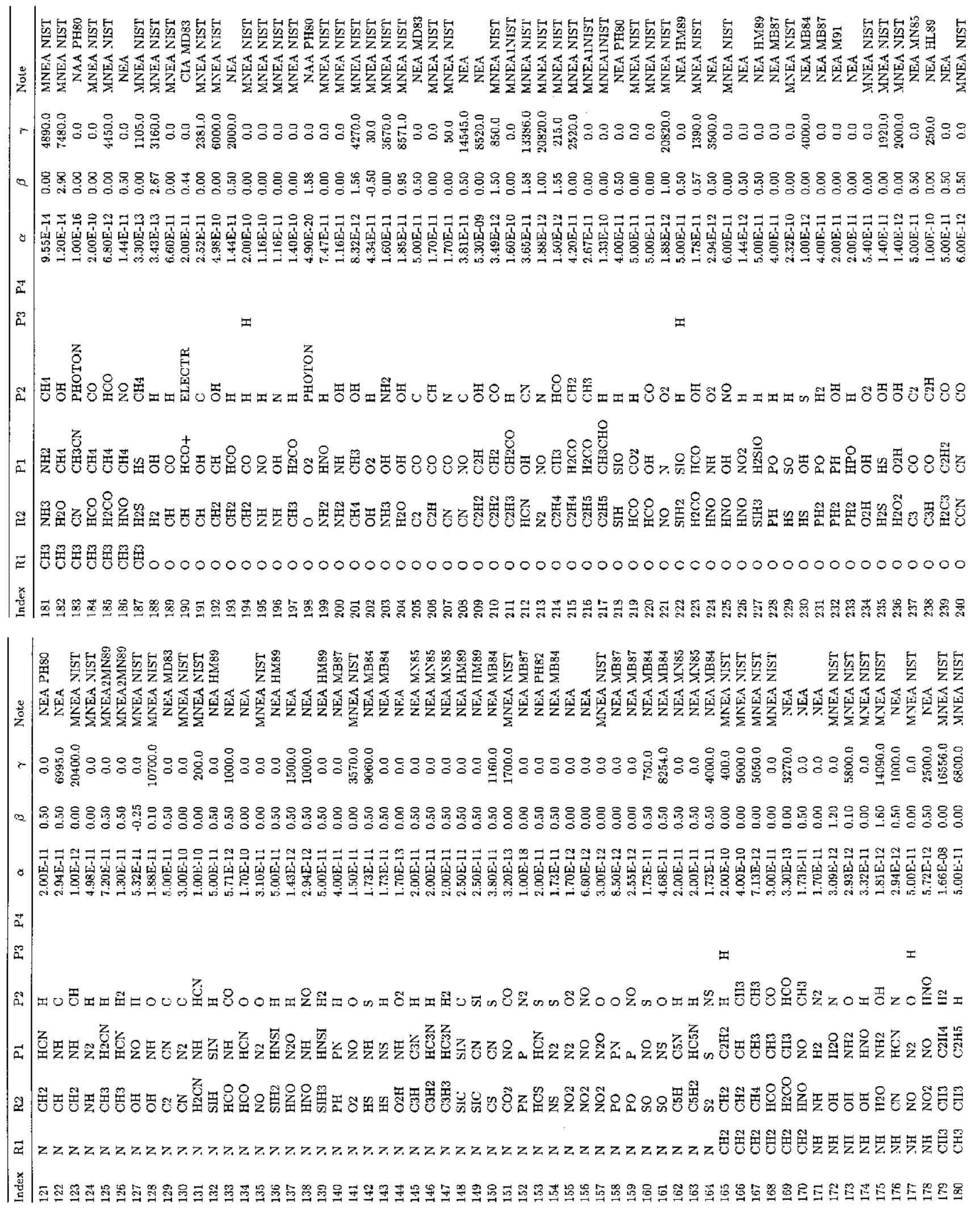
Table 4. continued

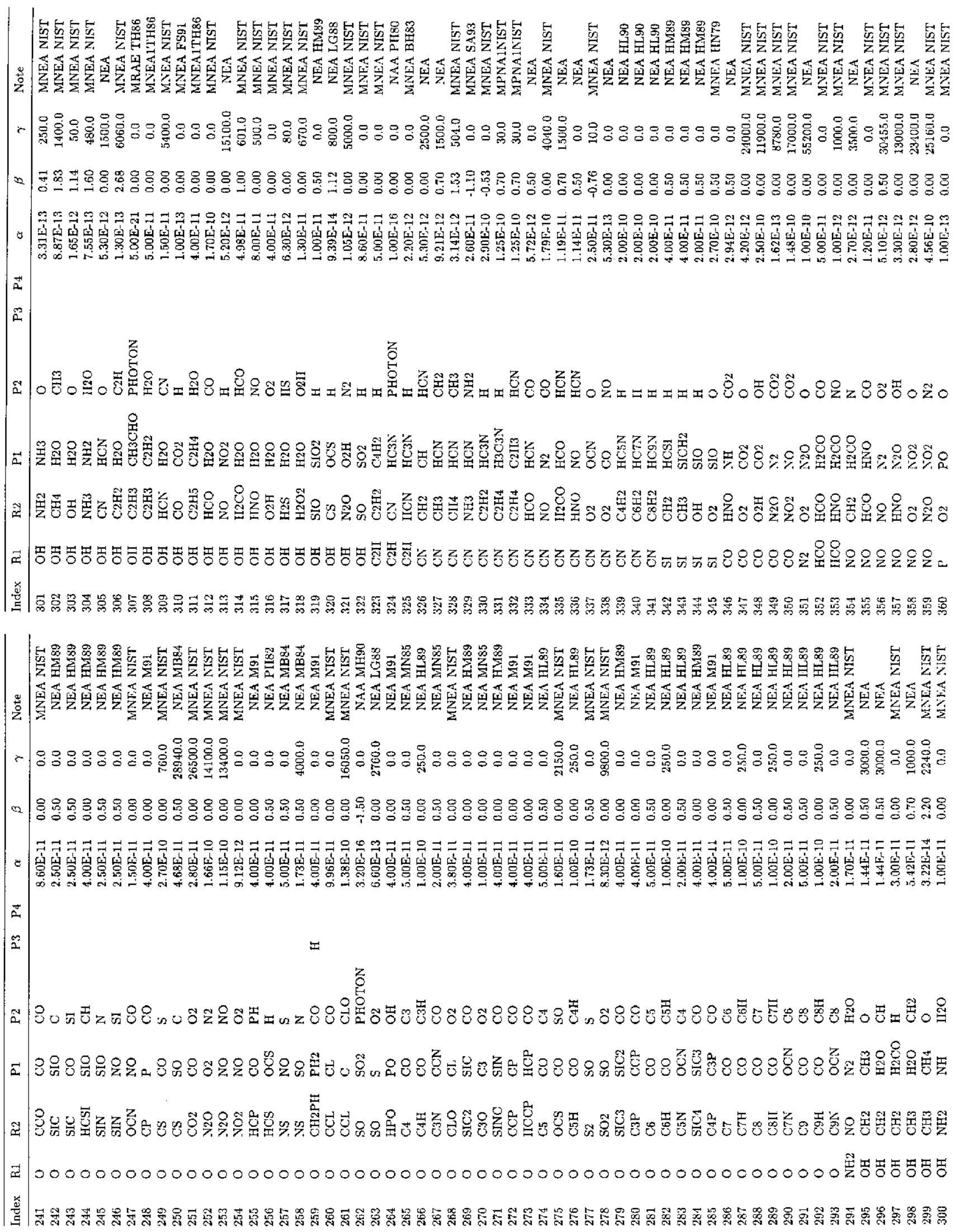


Table 4. continued

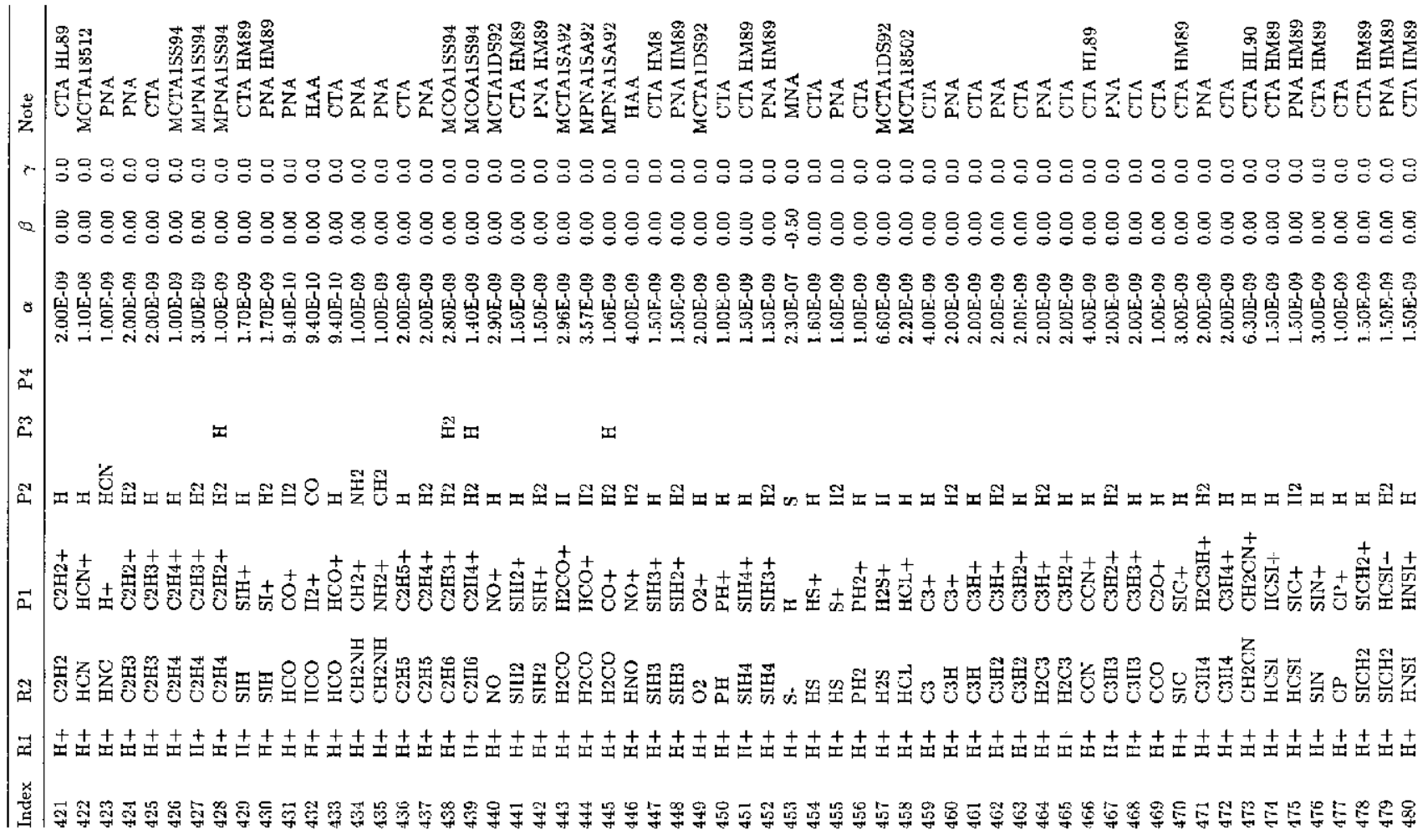

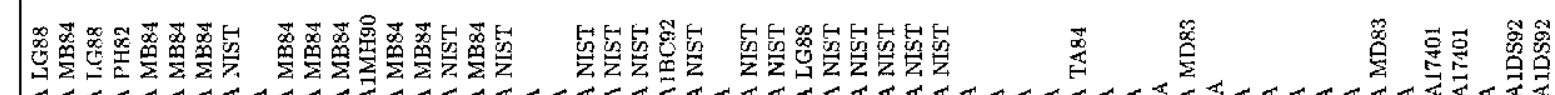

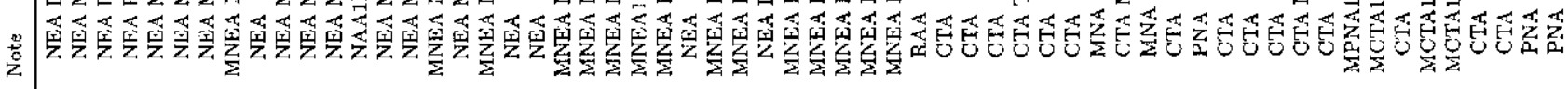

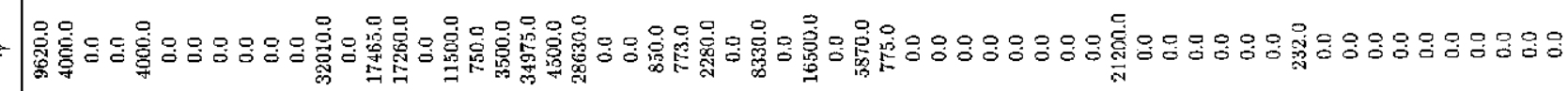

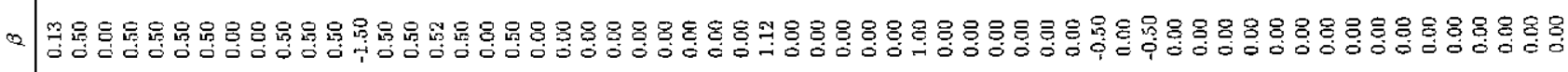

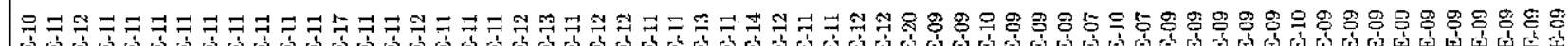

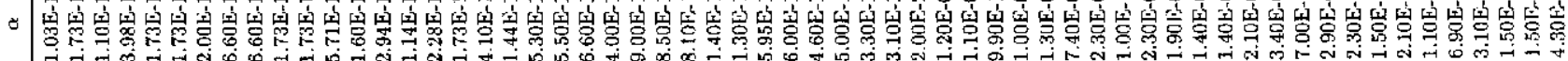
$\ddot{2}$ 2

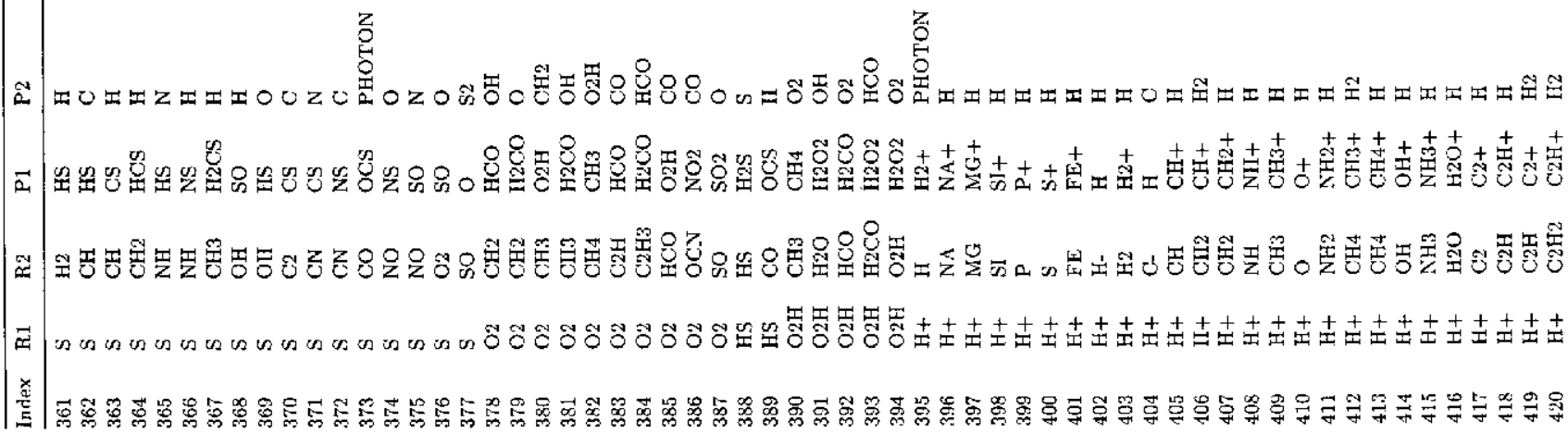


Table 4. continued
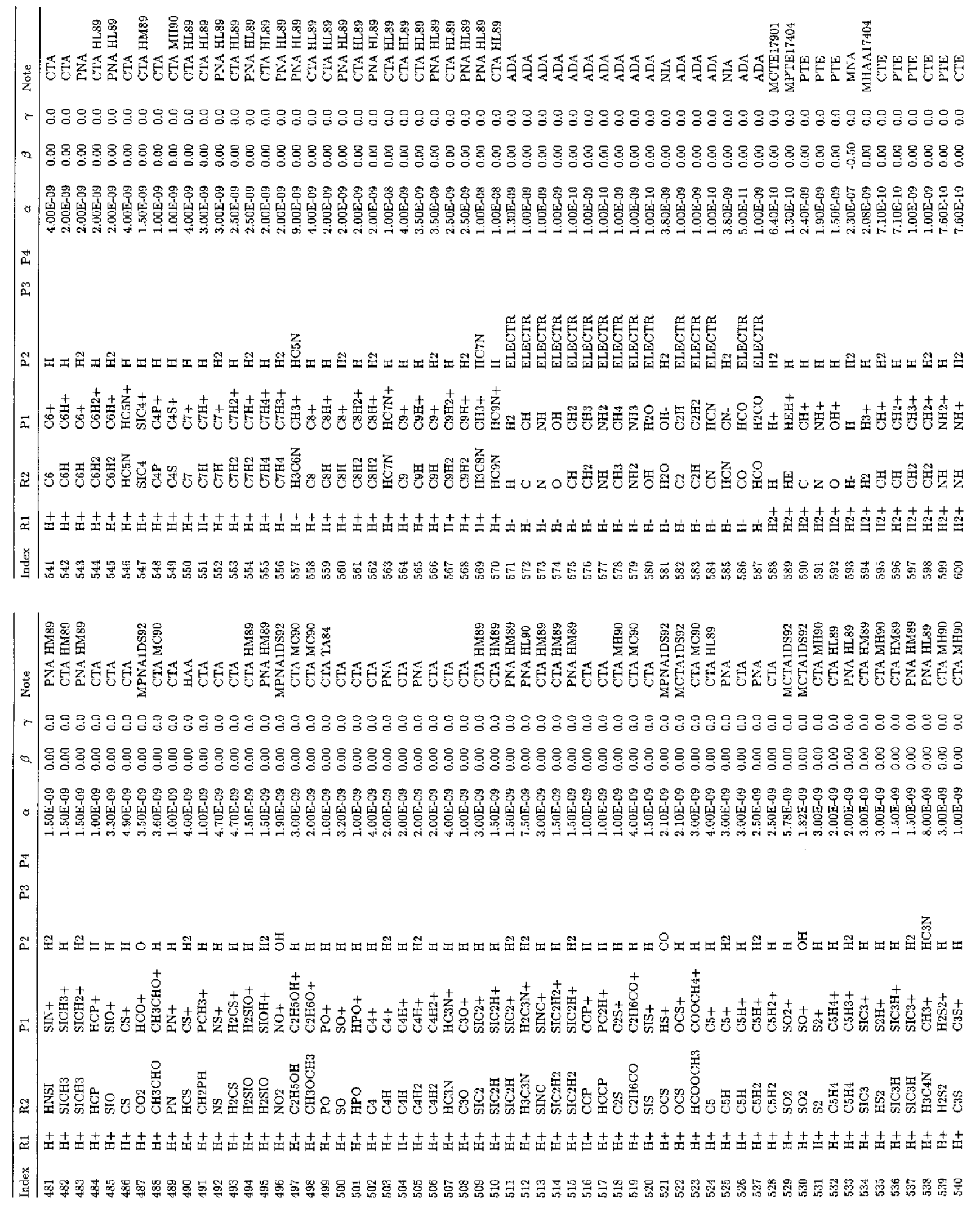
Table 4. continued

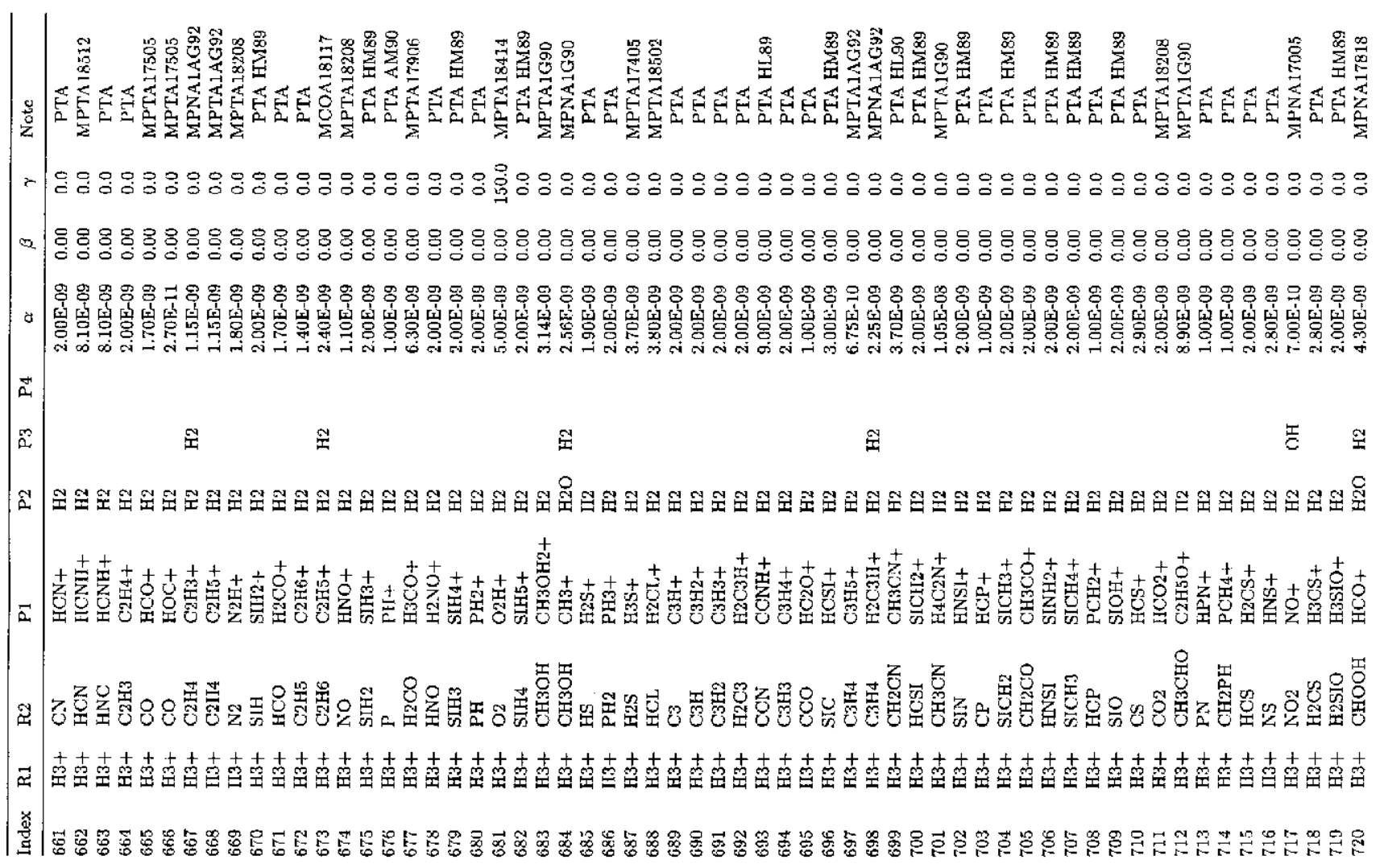

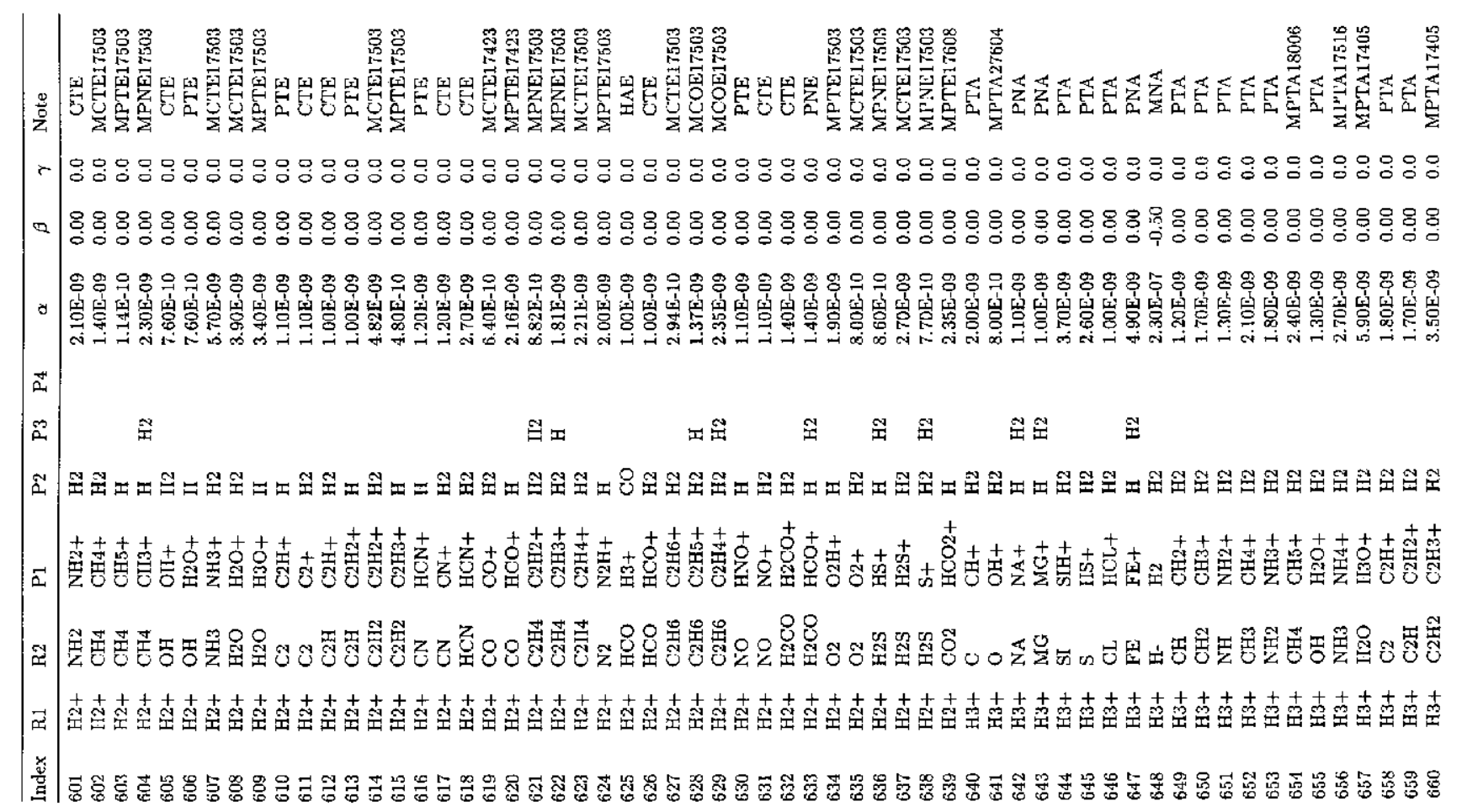


Table 4. continued

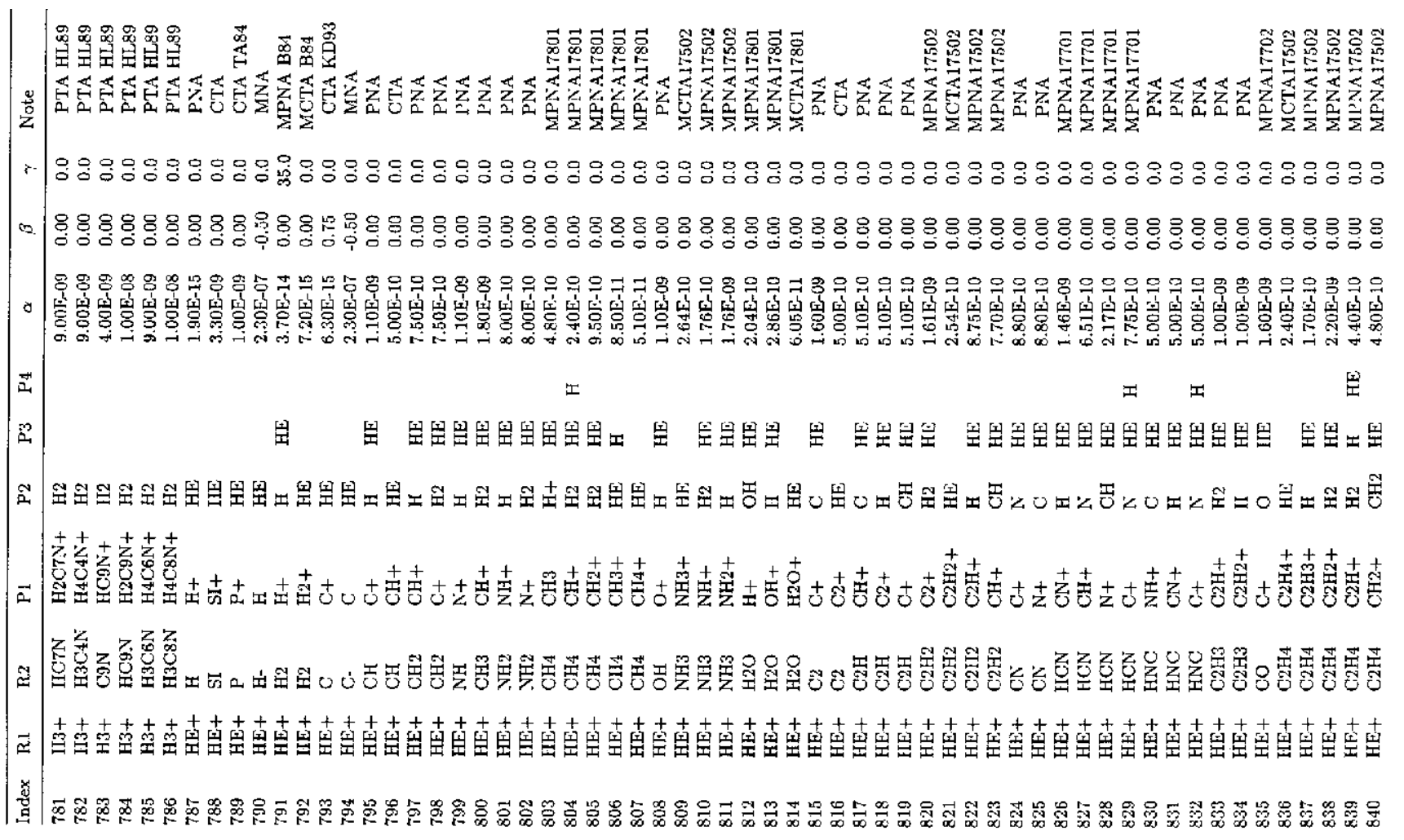

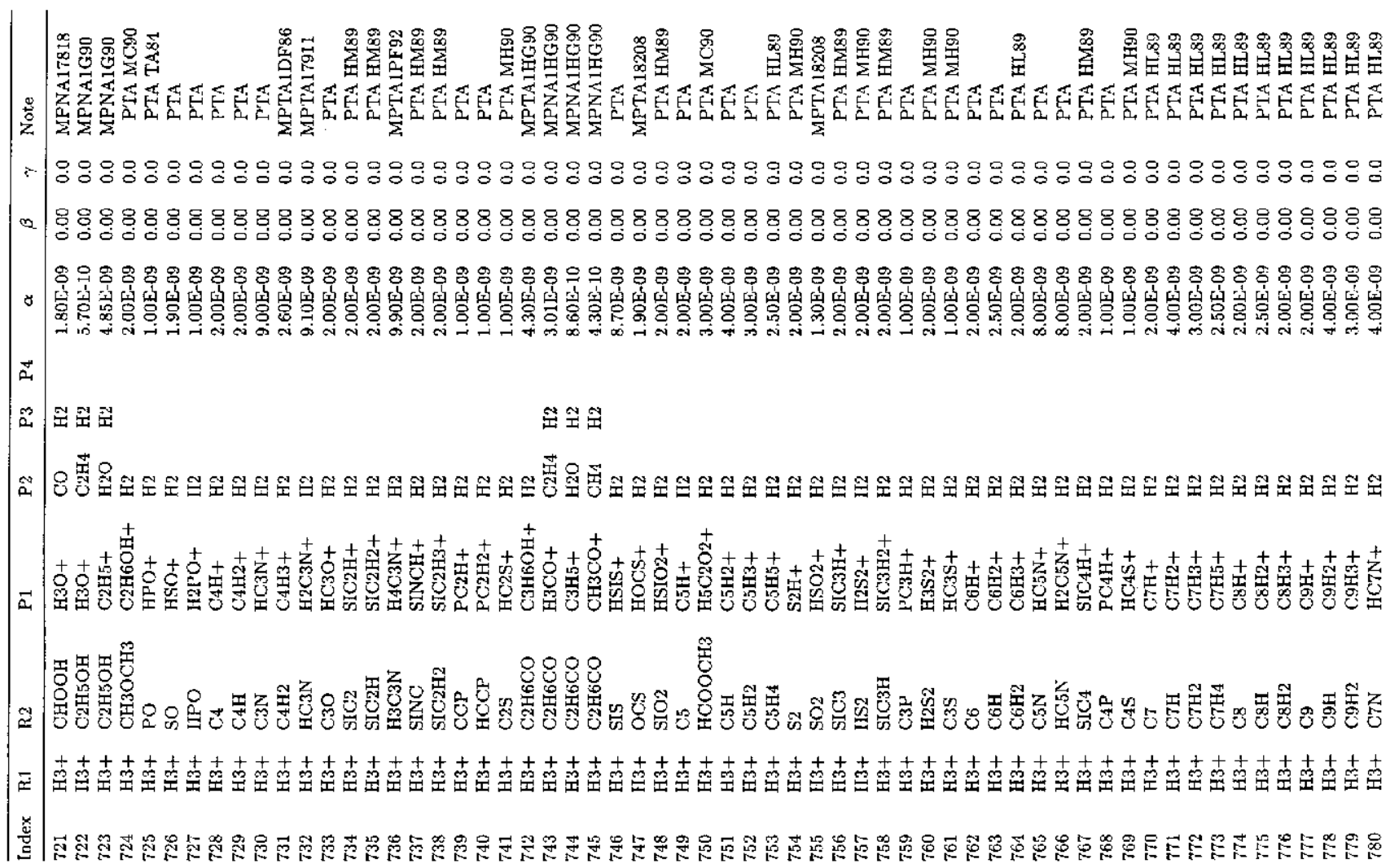


Table 4. continued

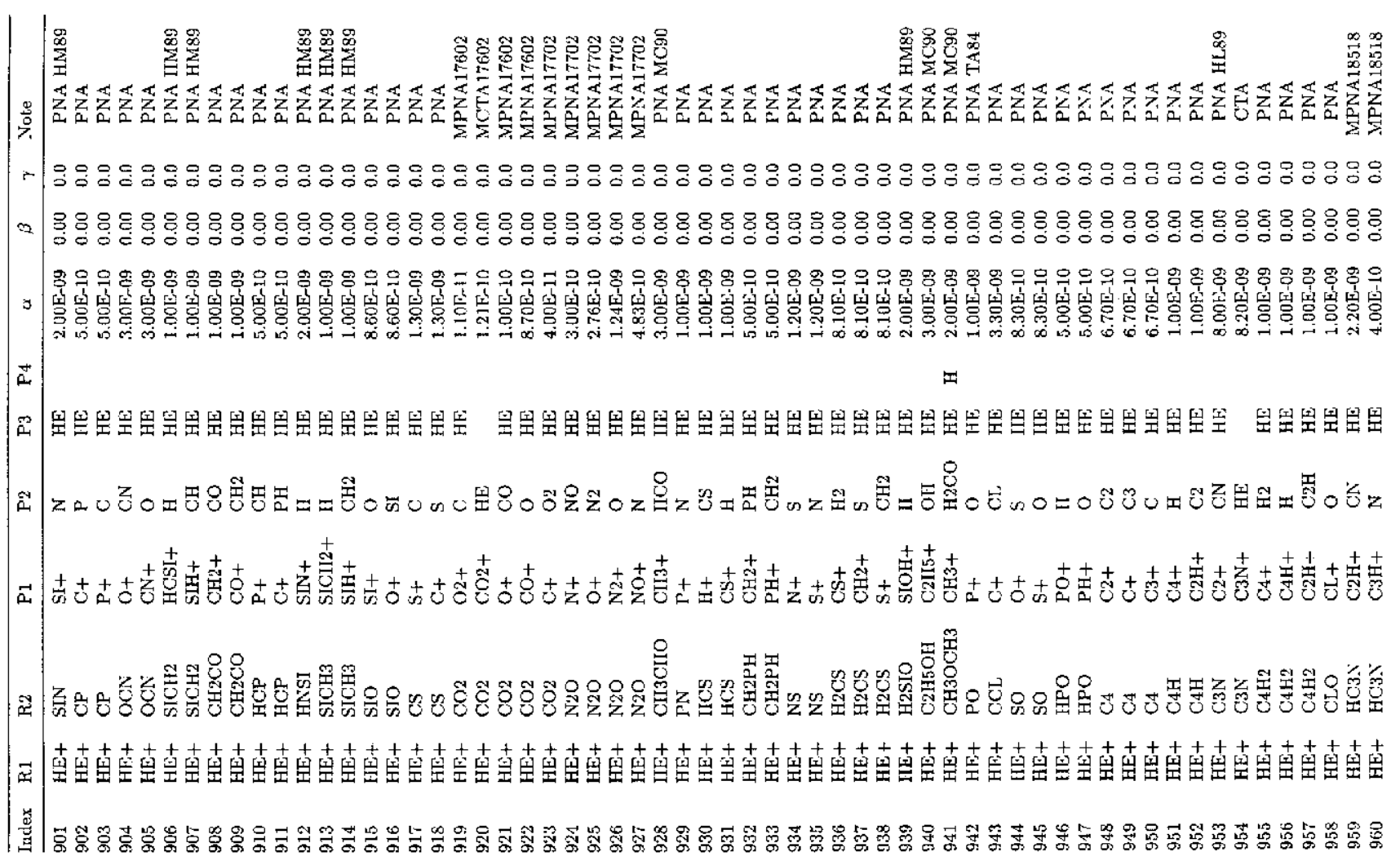

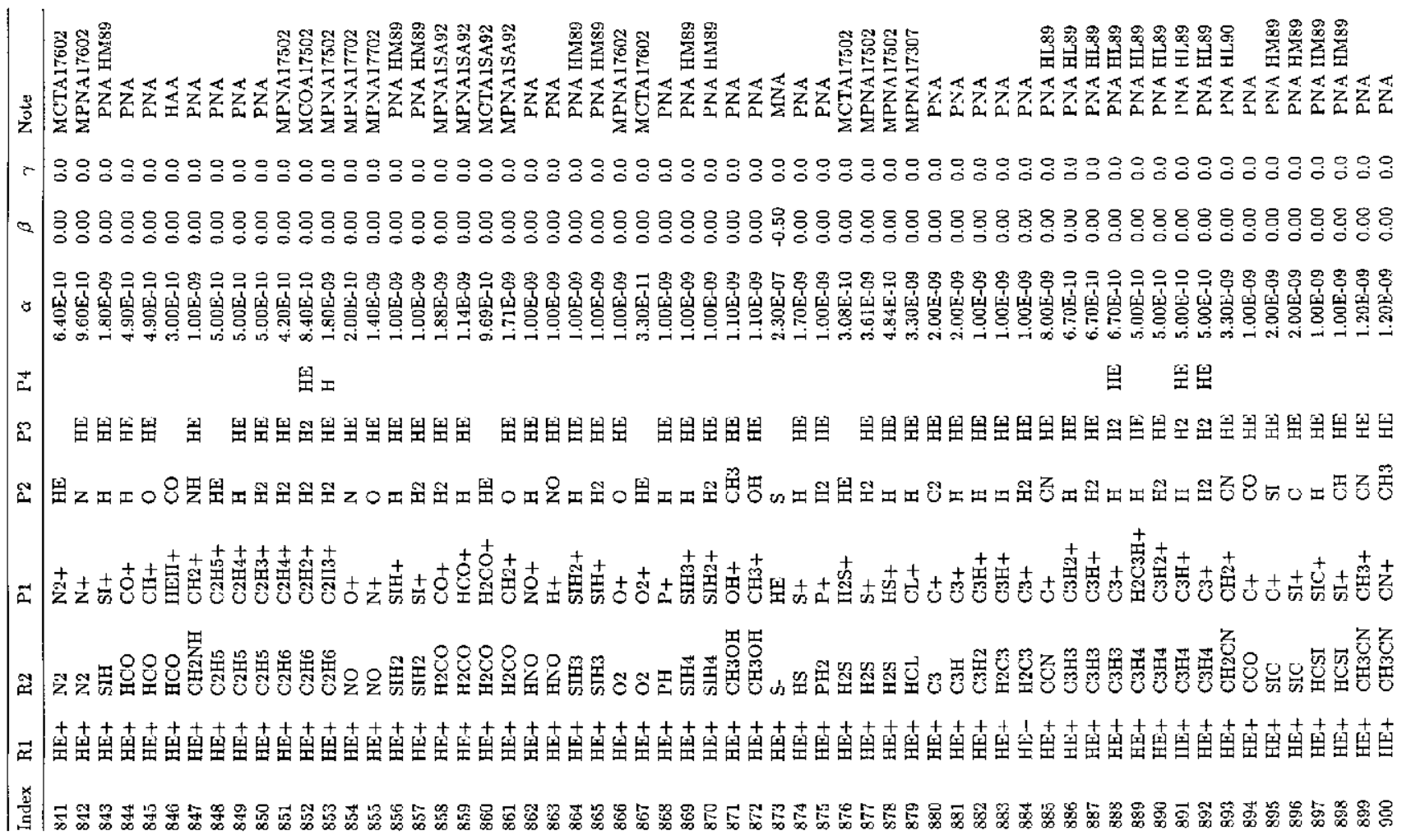


Table 4. continued

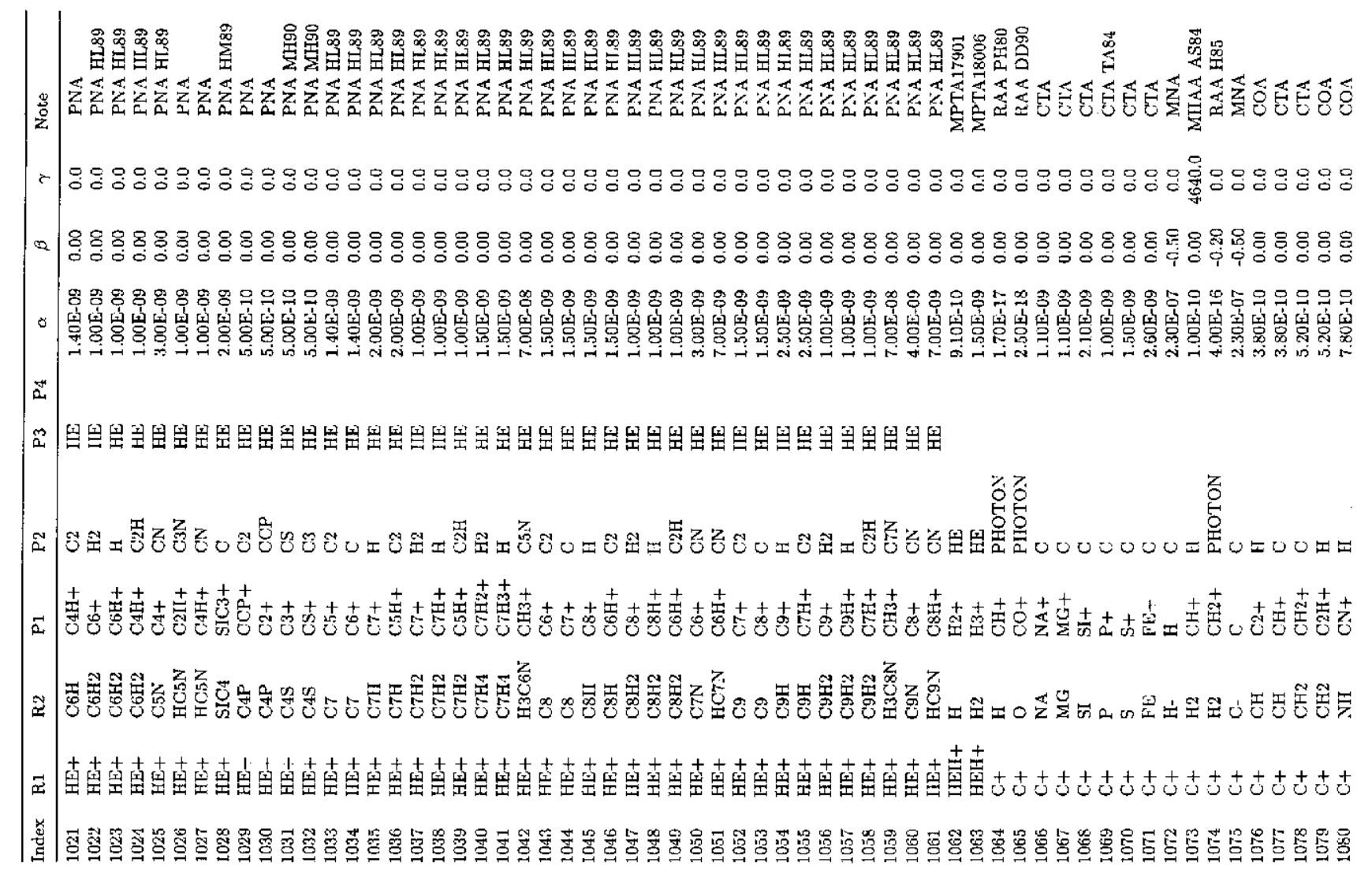

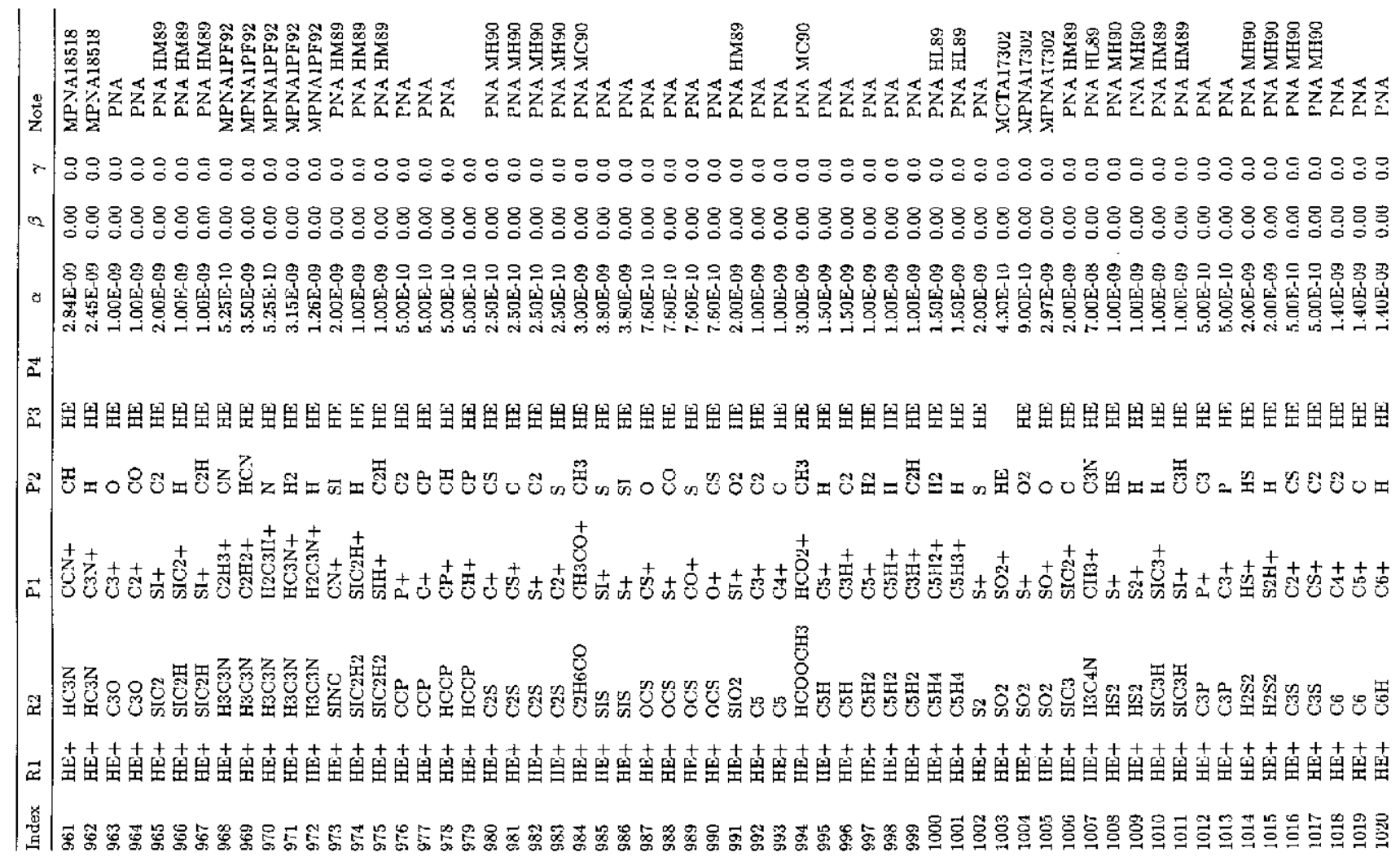


Table 4. continued
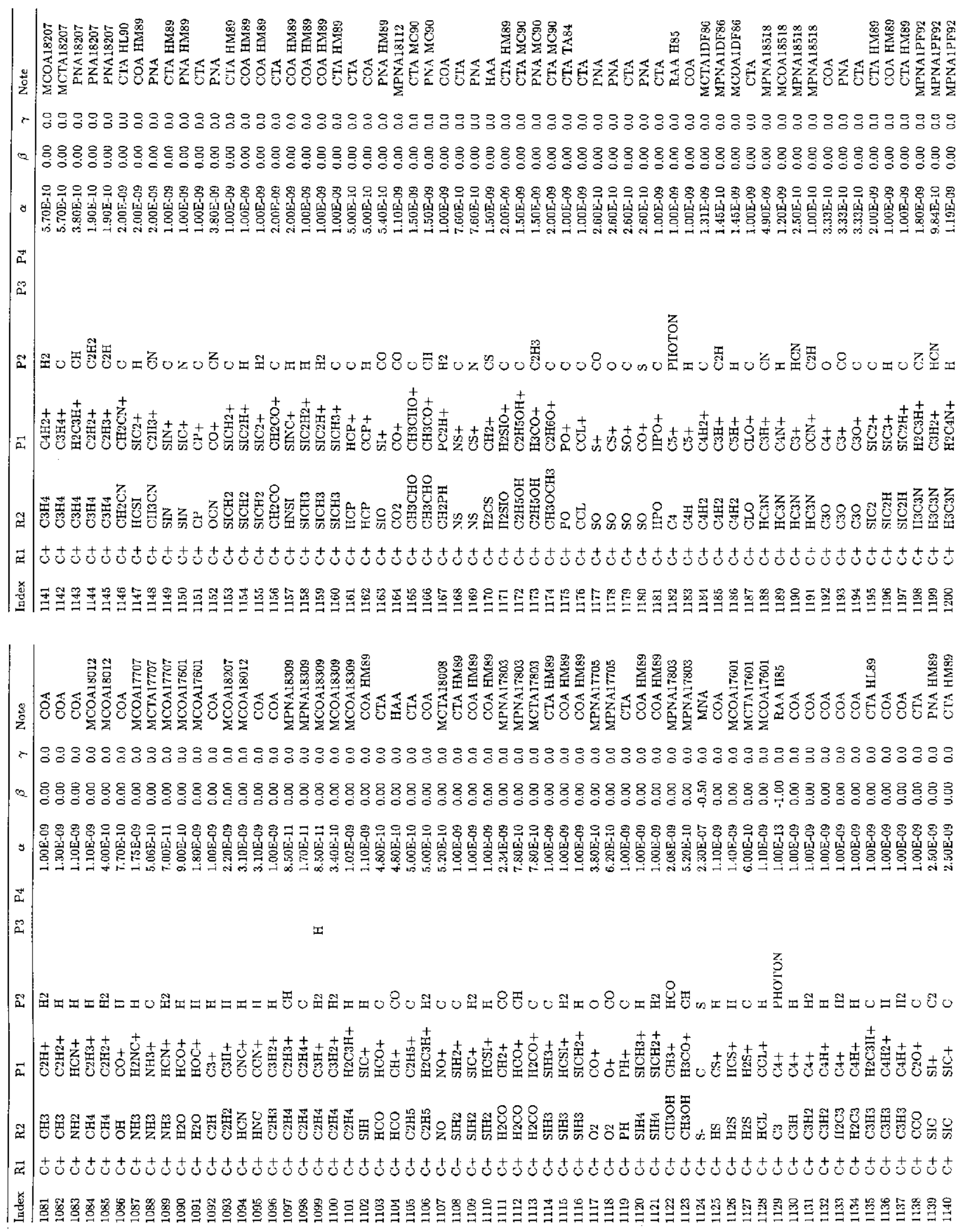
Table 4. continued

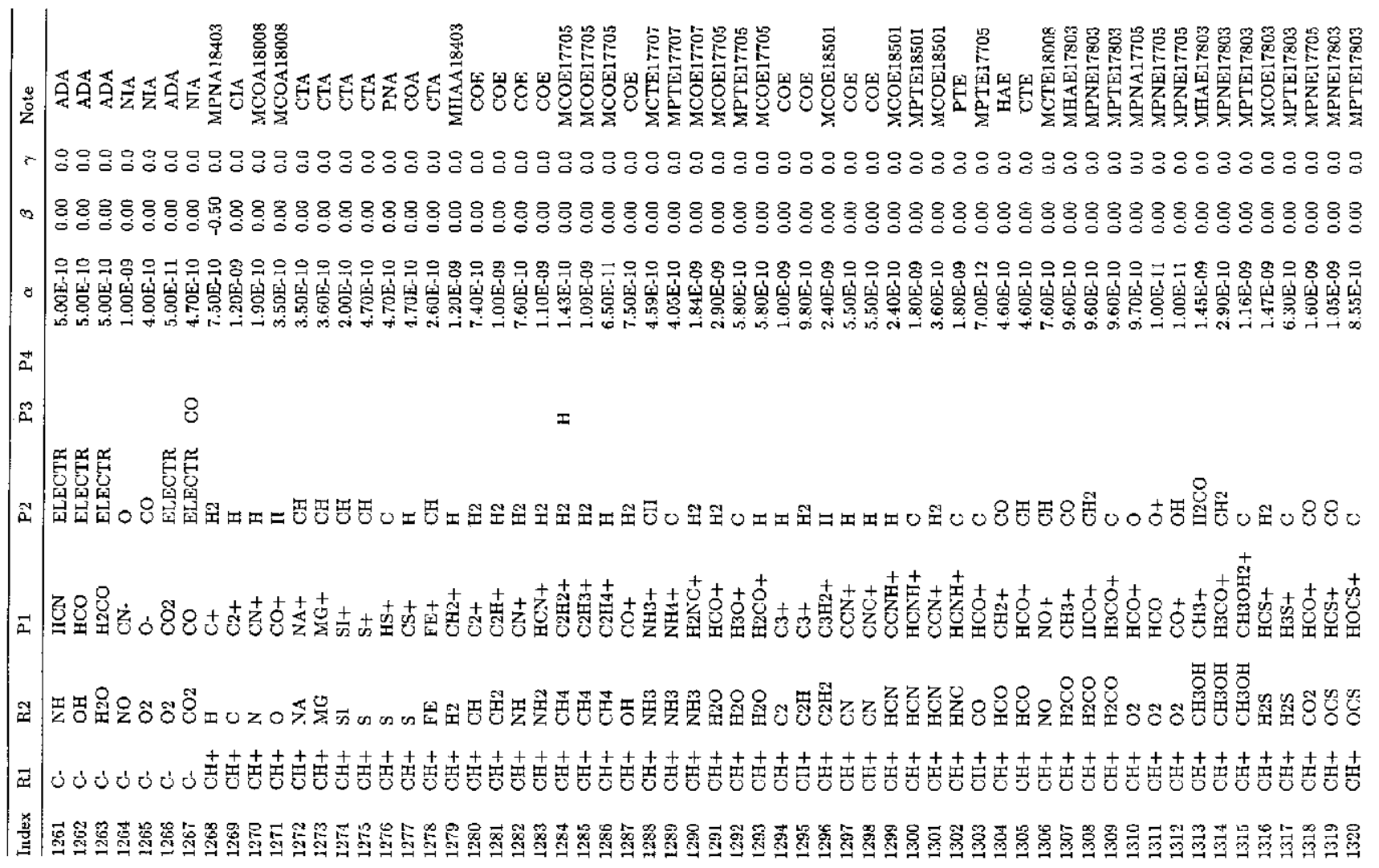

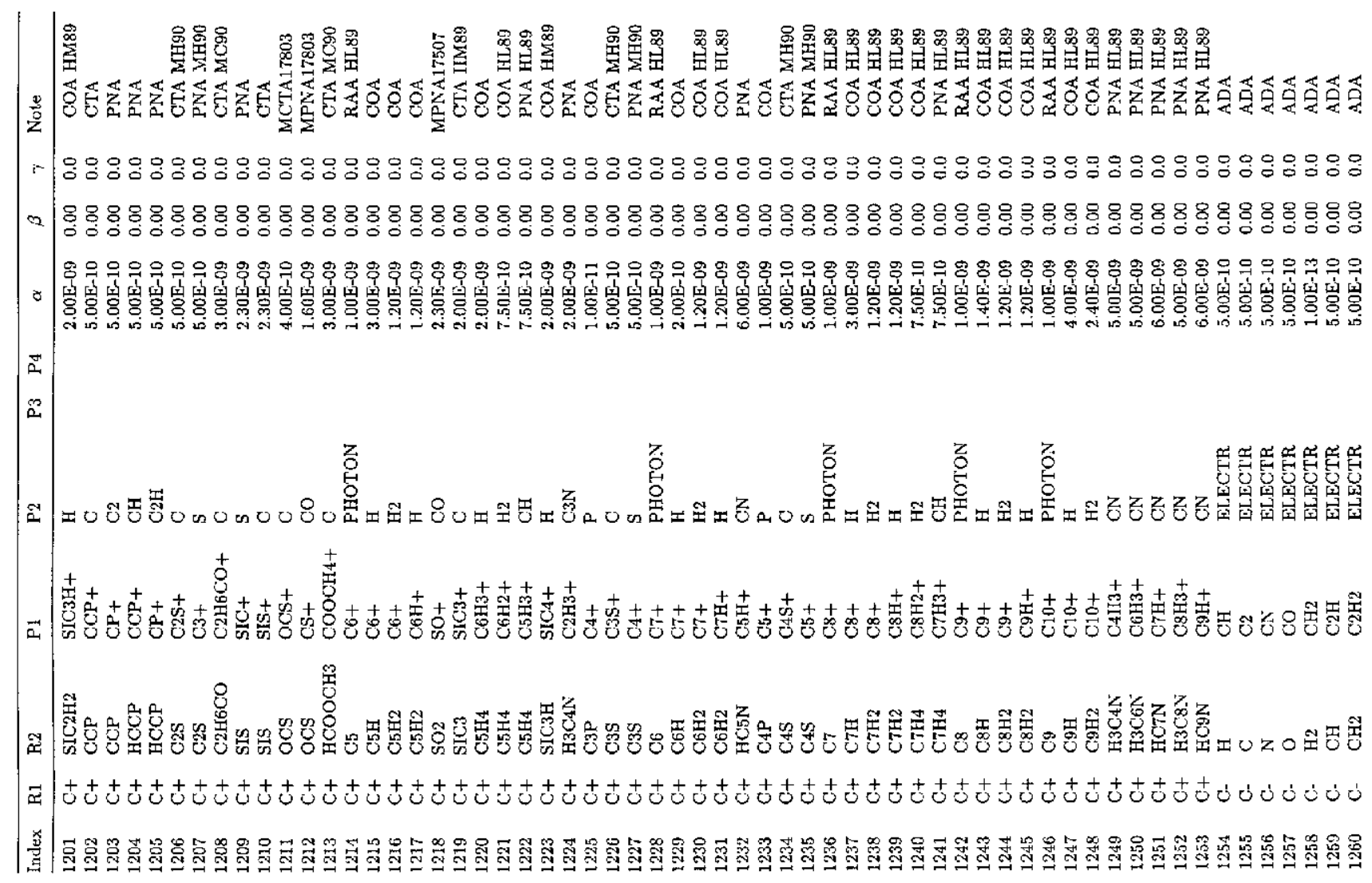


Table 4. continued

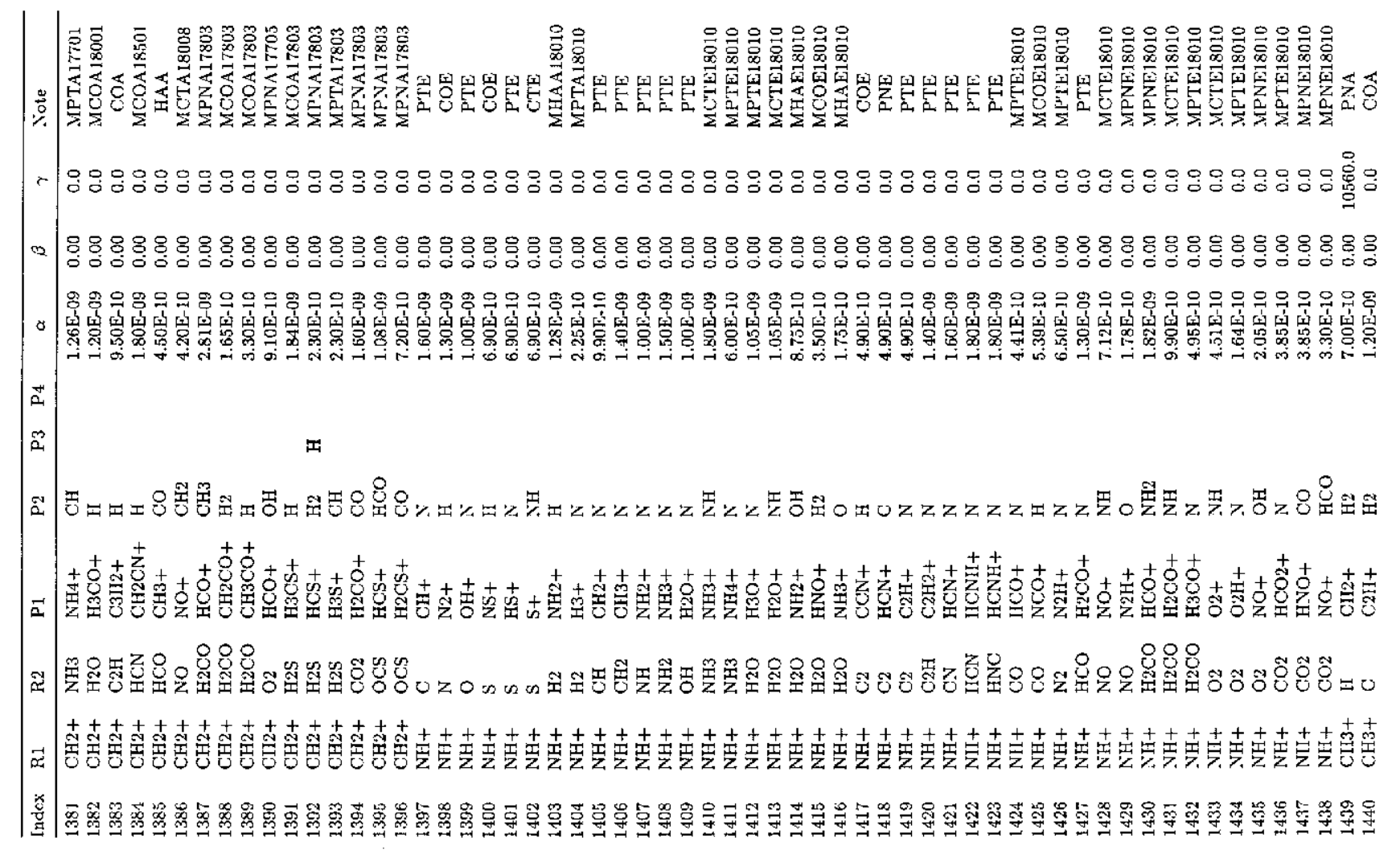

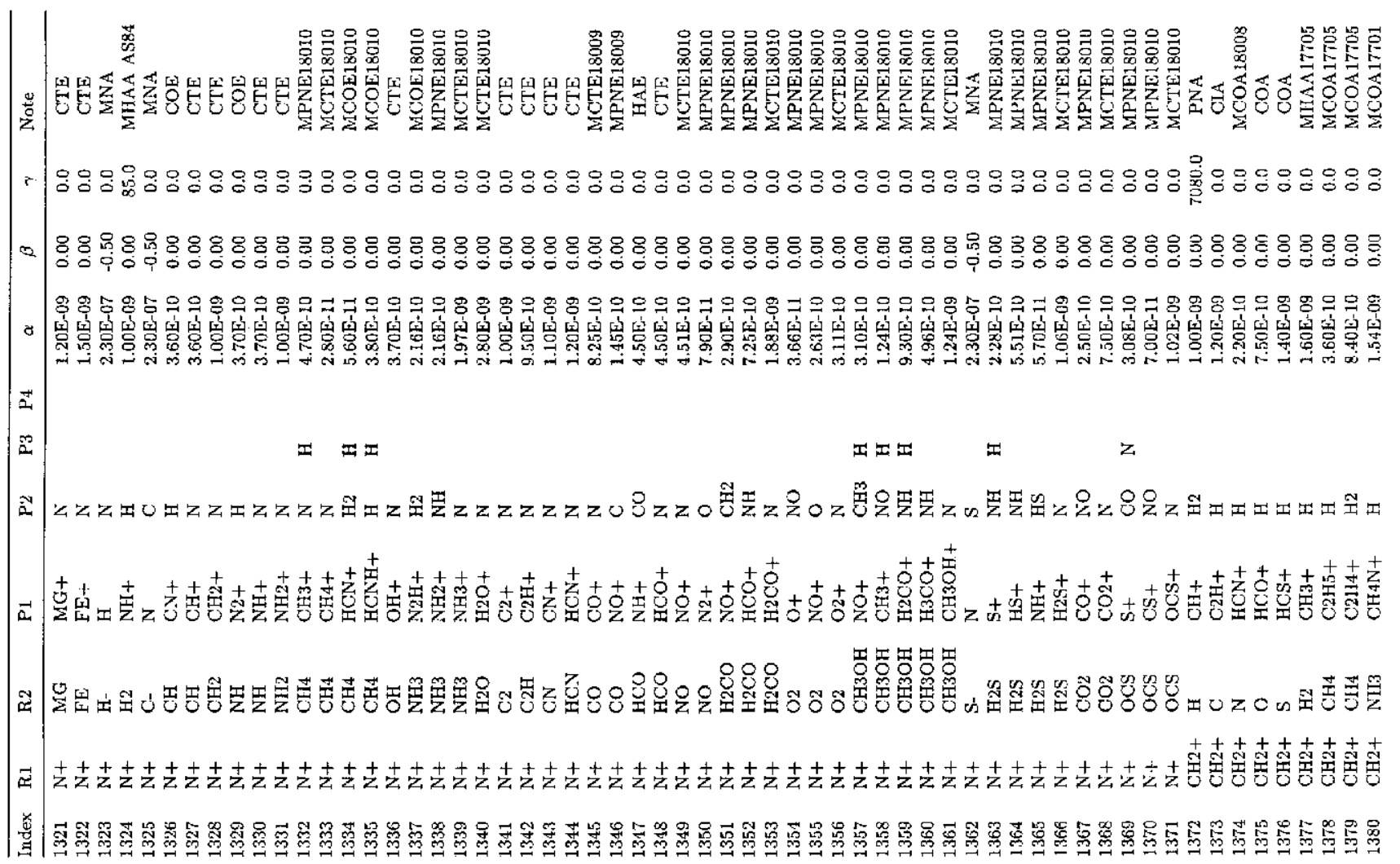


Table 4. continued

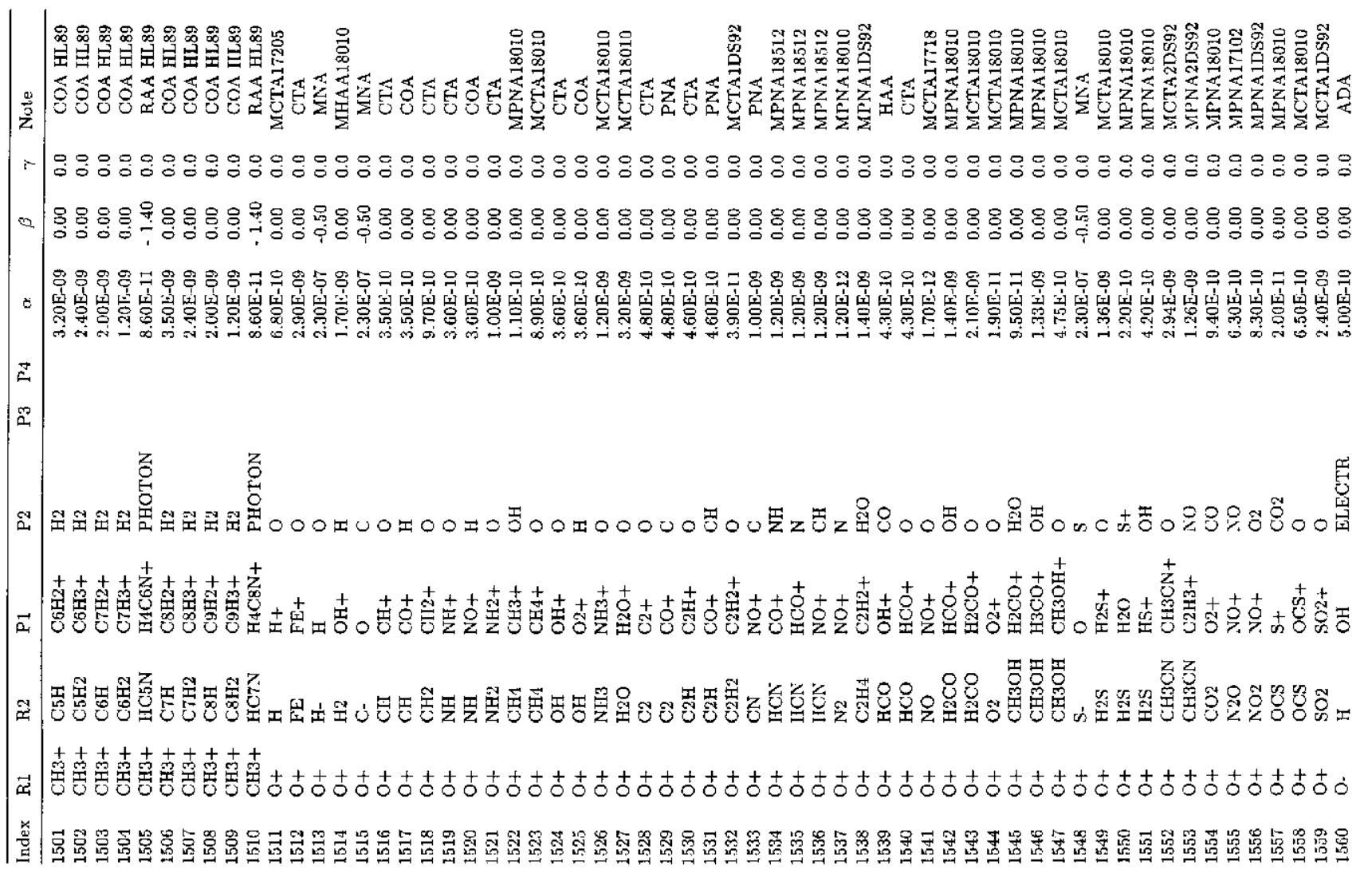

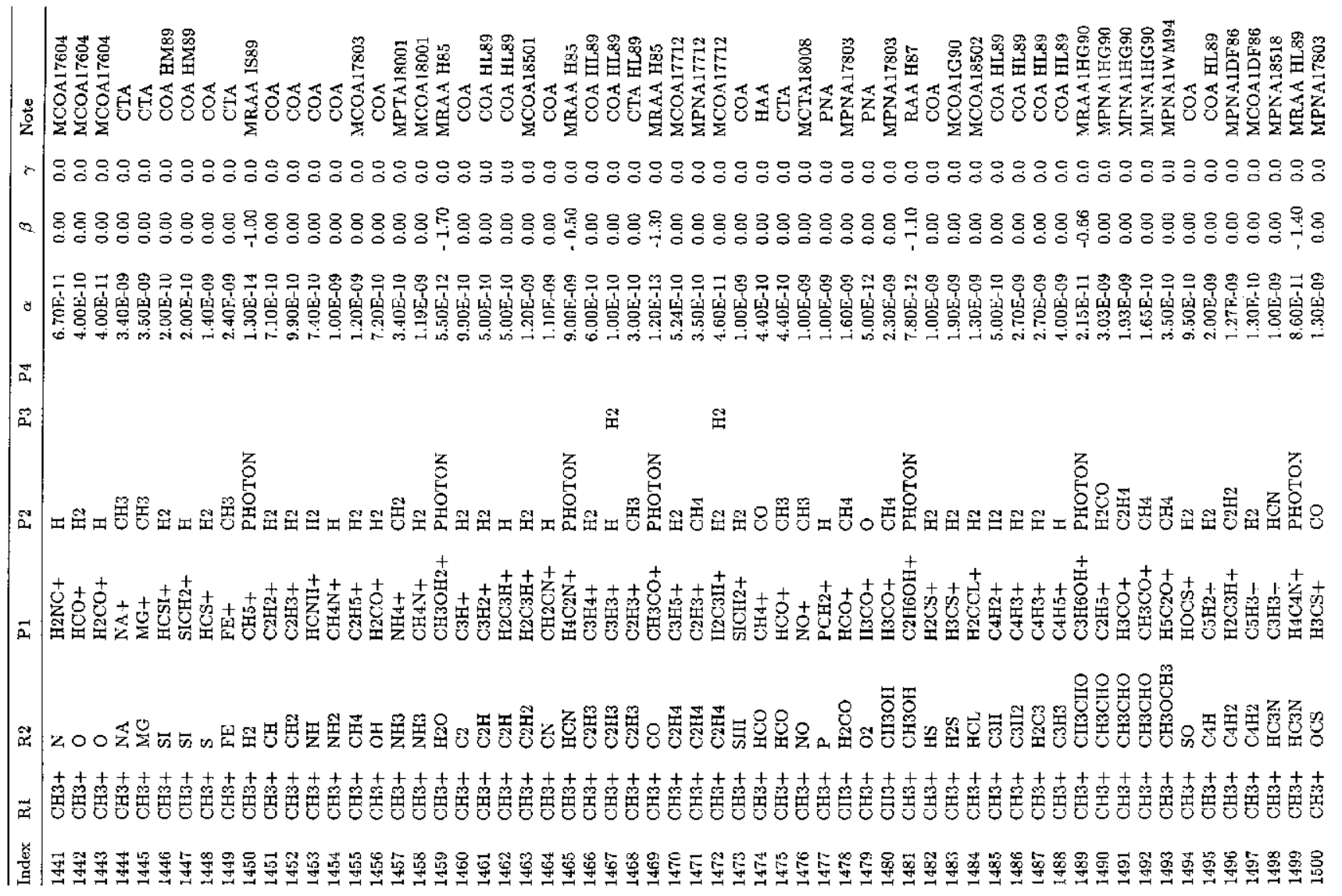


Table 4. continued

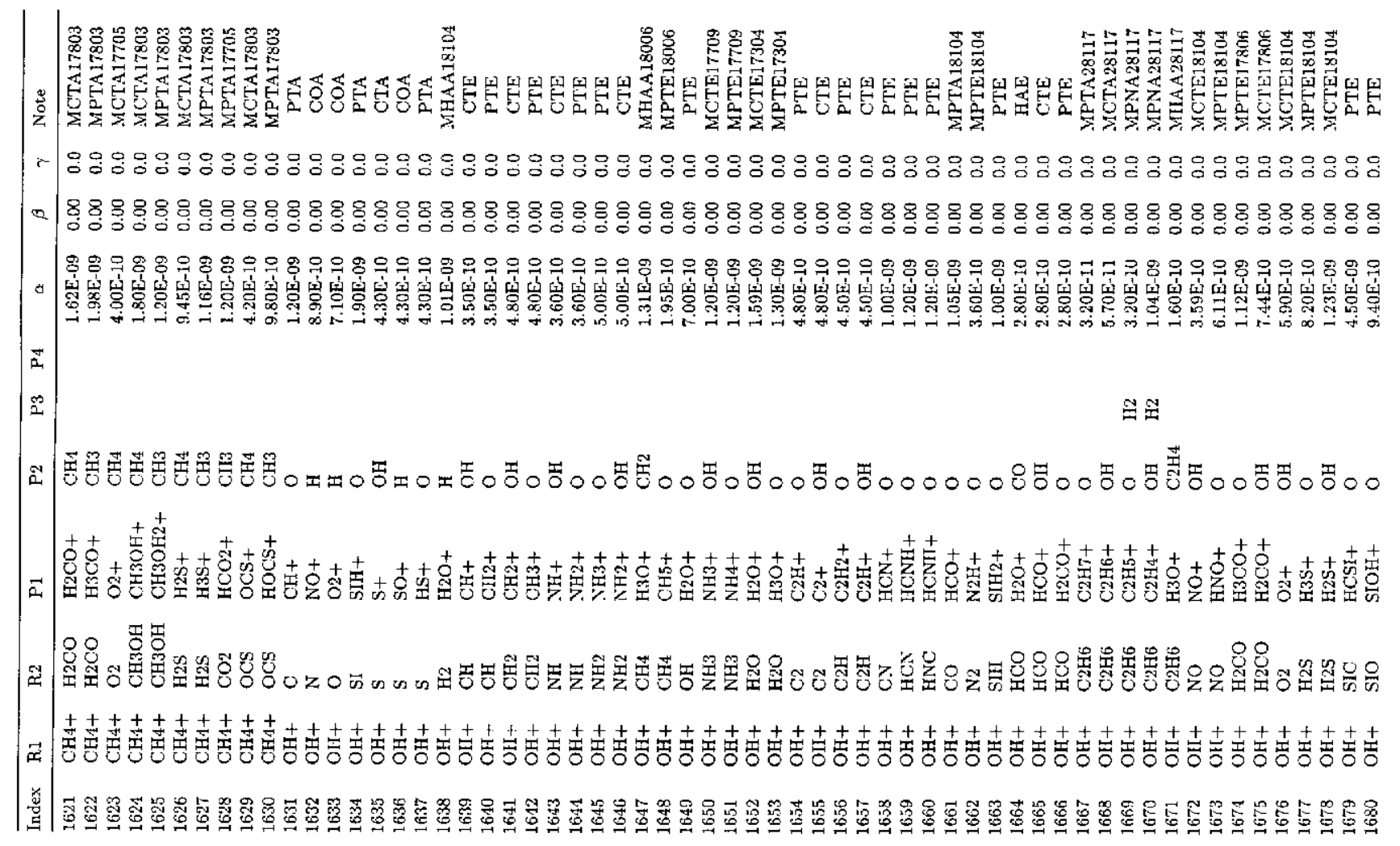

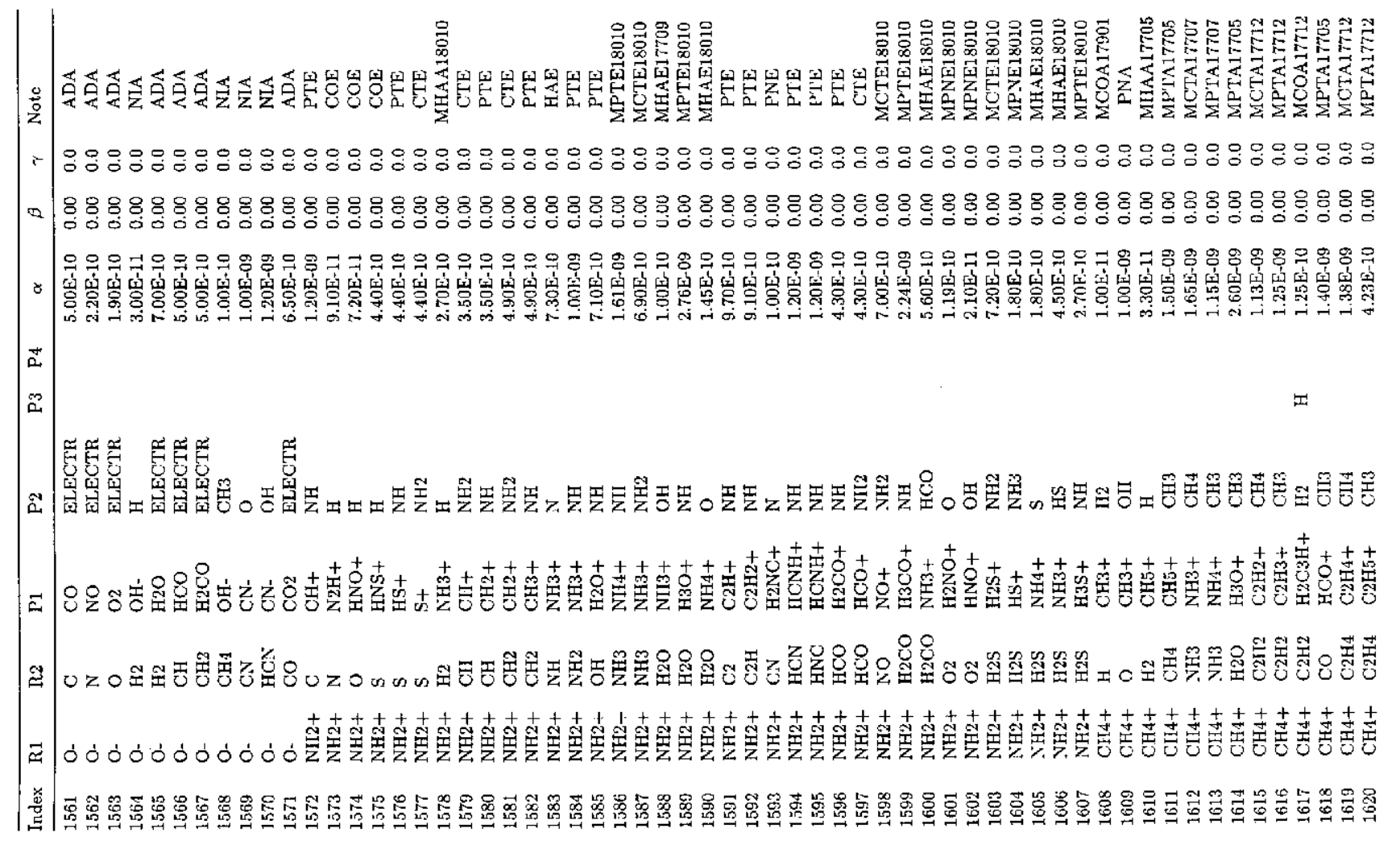


Table 4. continued

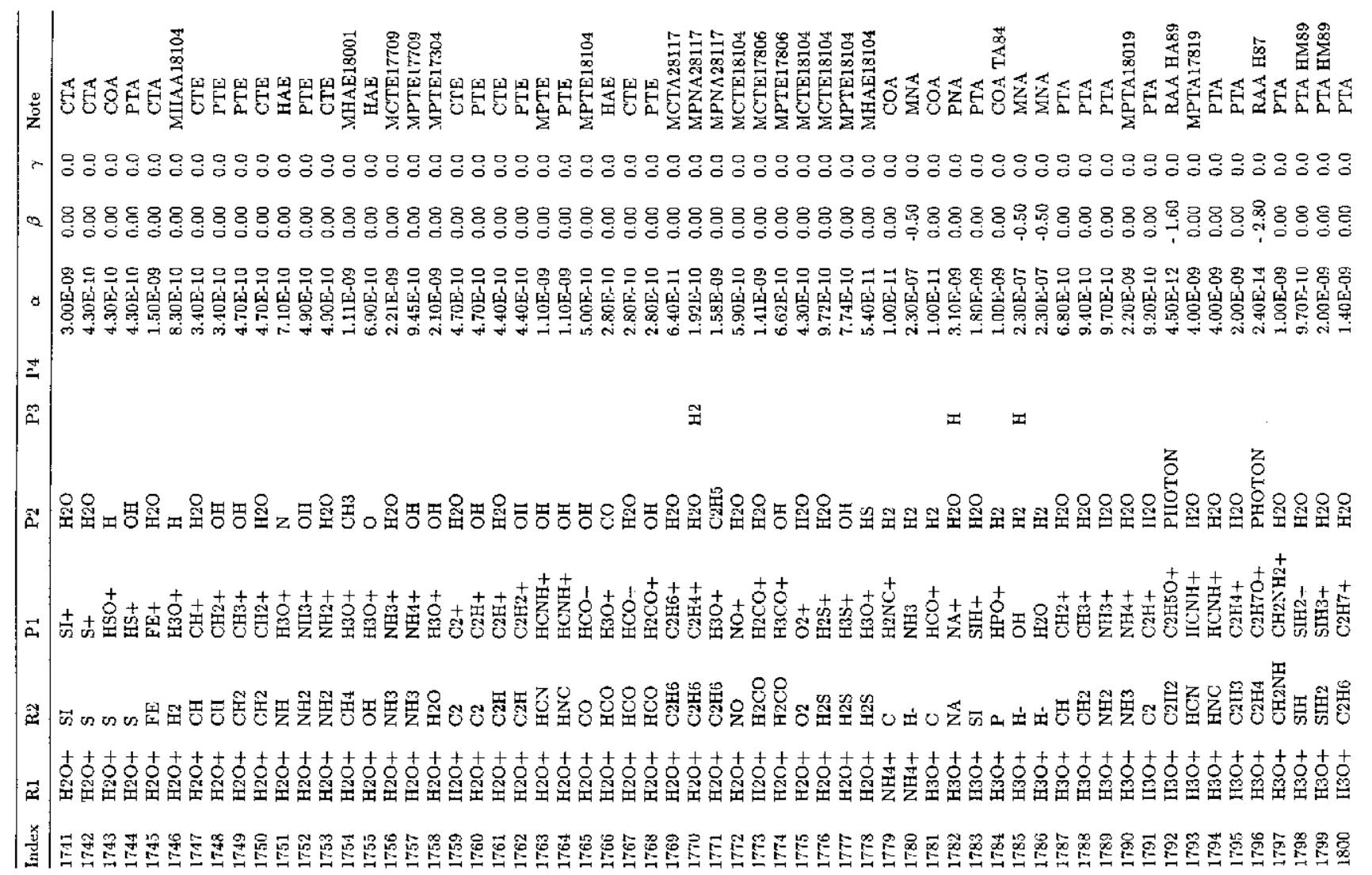
|

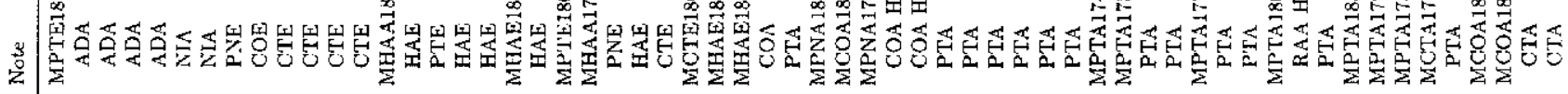

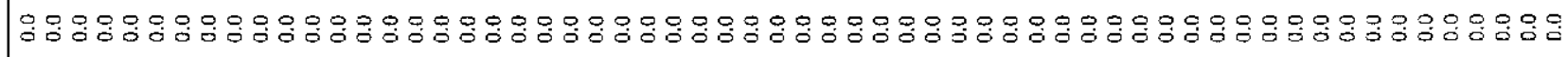

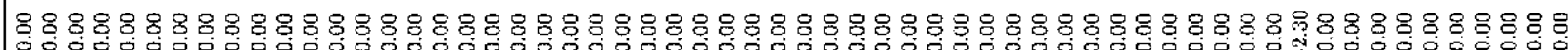

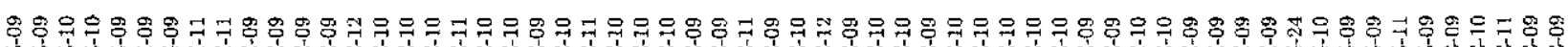

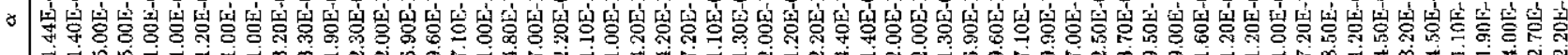
ت्ञ a 田

我结象

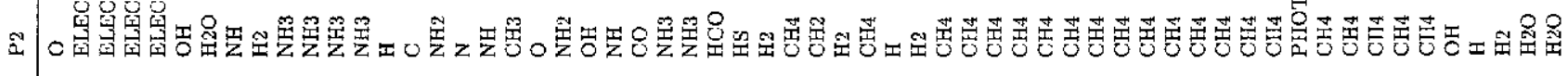

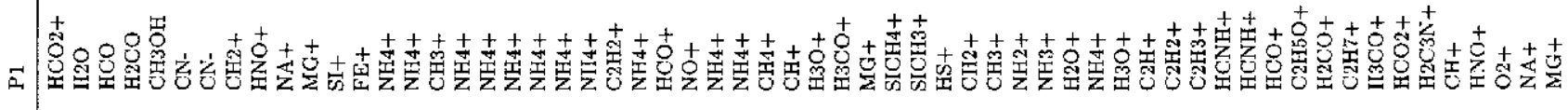

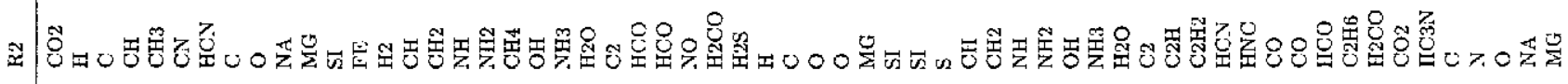

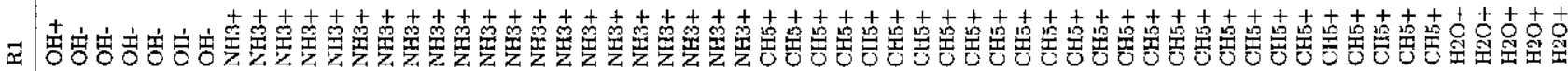

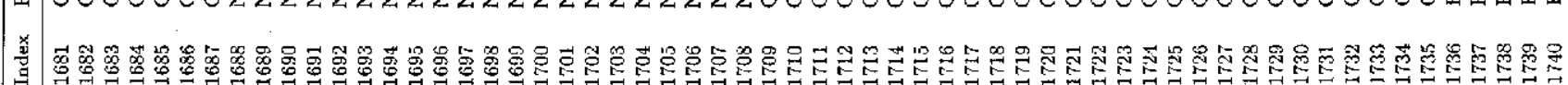


Table 4. continued

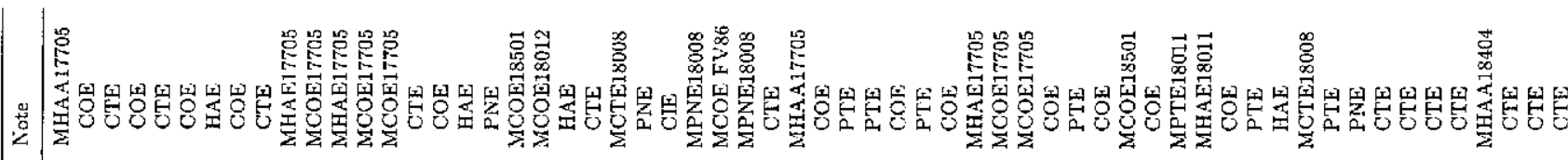

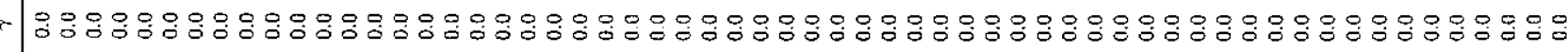

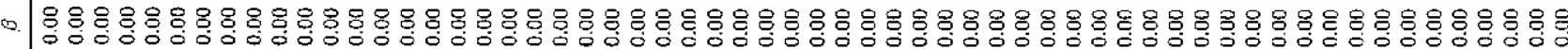

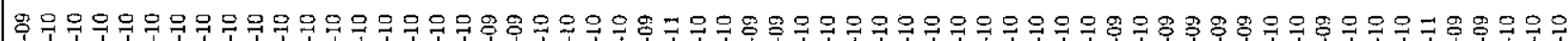

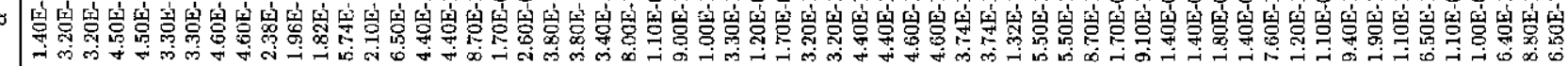
芒

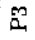
보

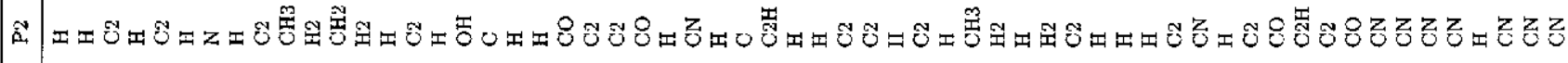

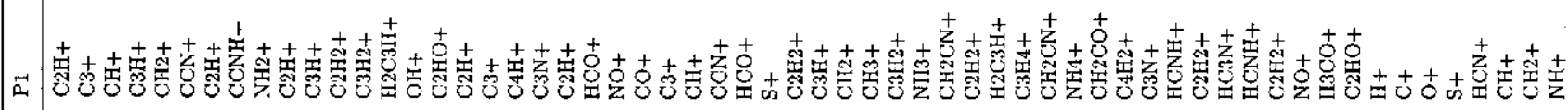

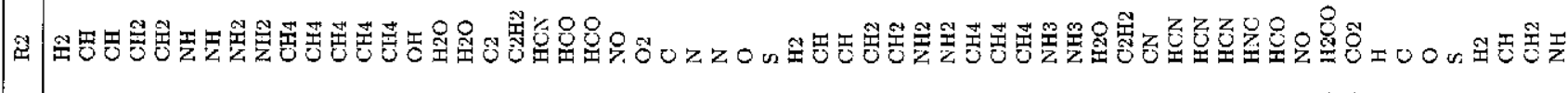

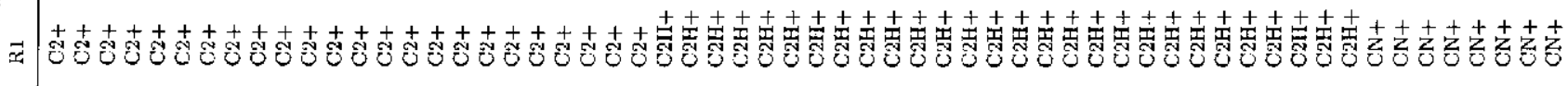

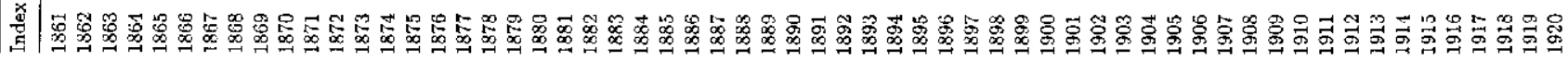

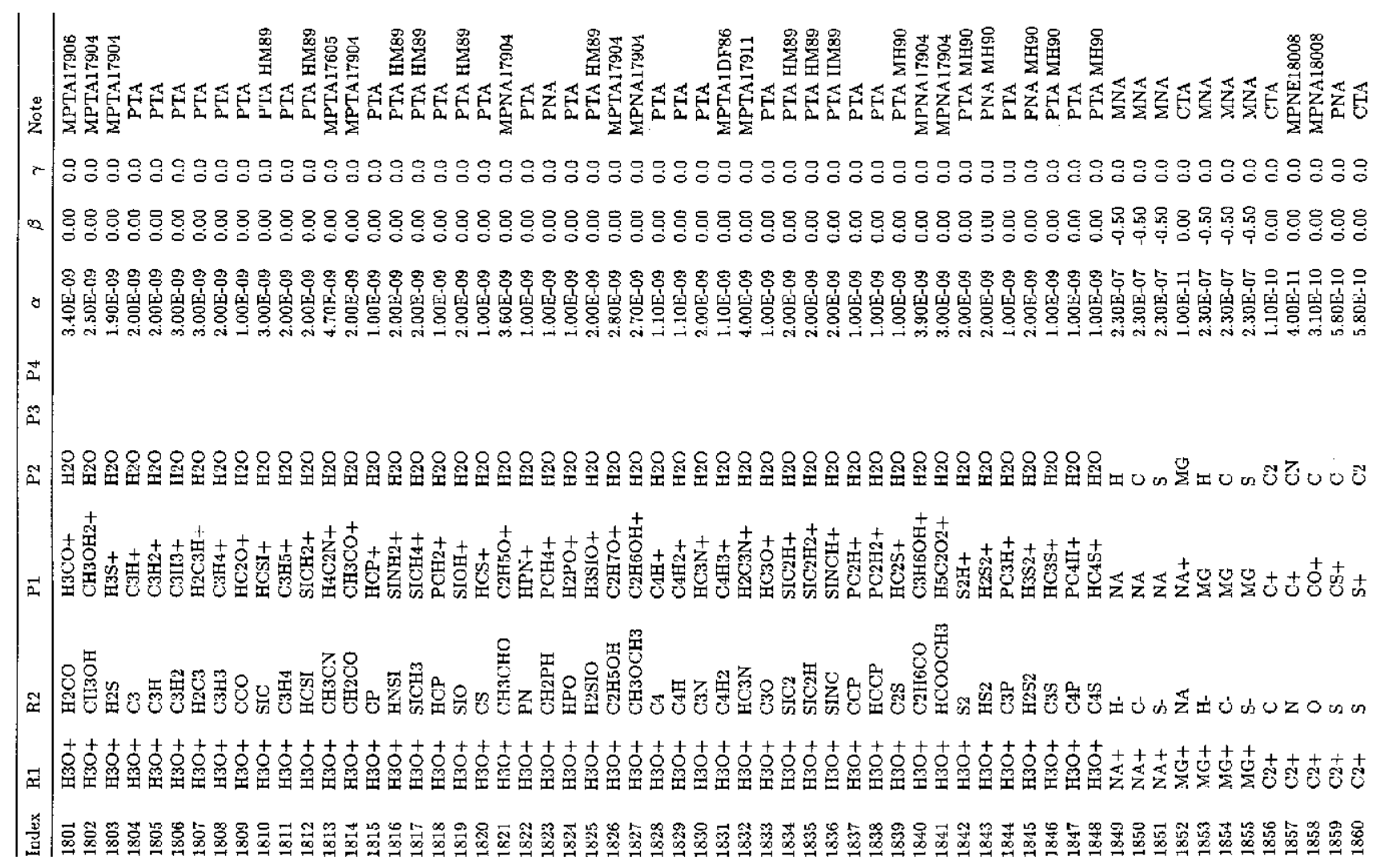


Table 4. continued

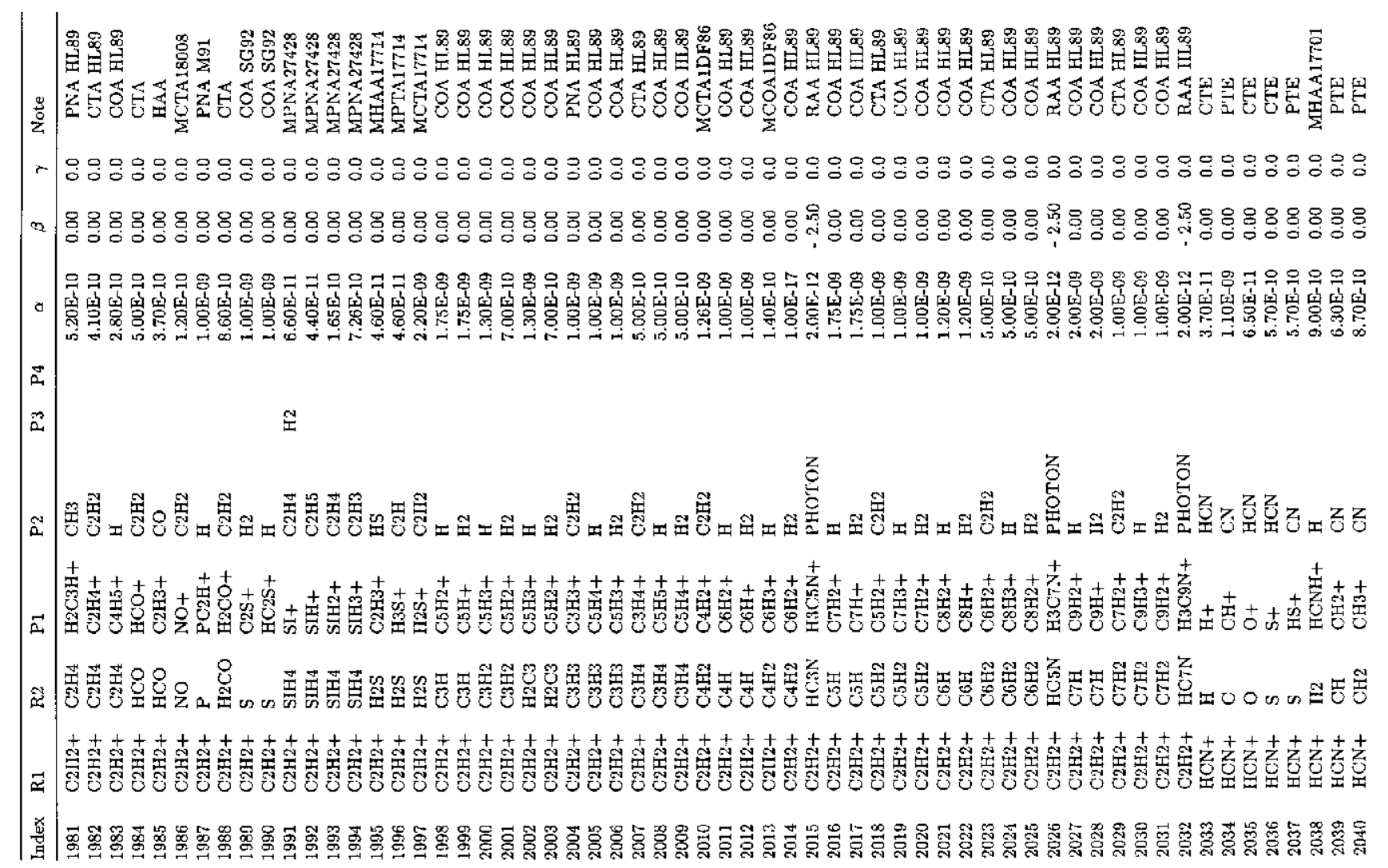

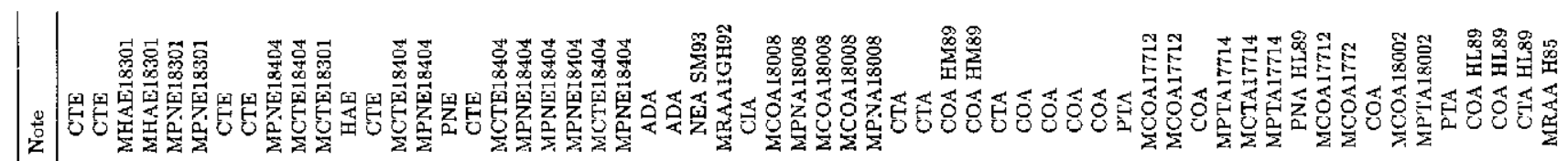

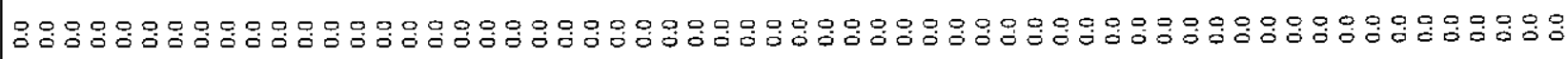

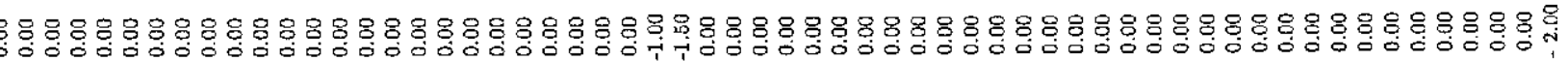

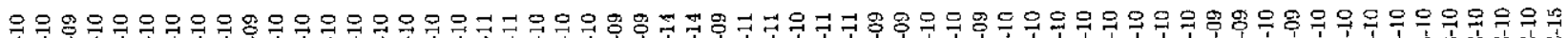

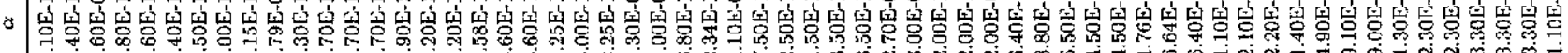

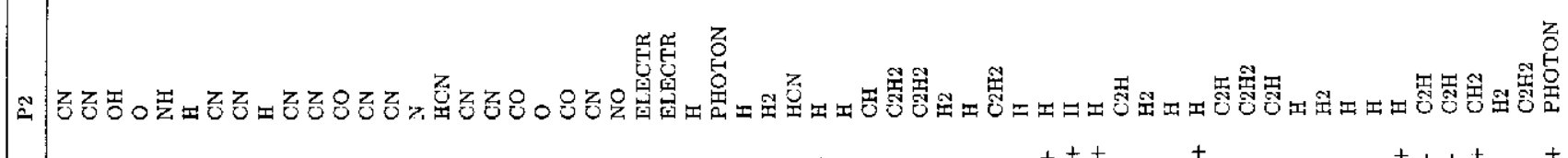

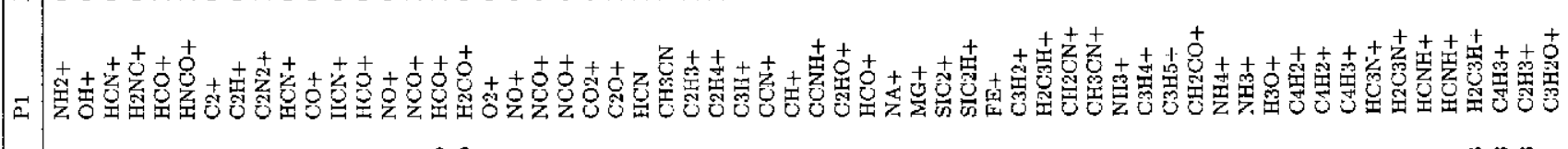

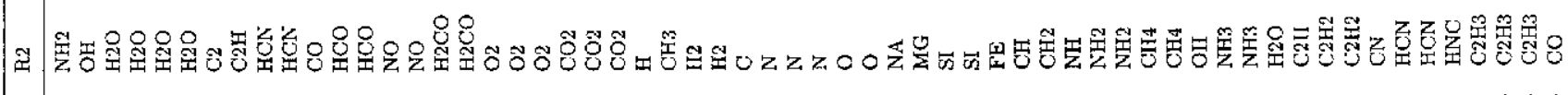

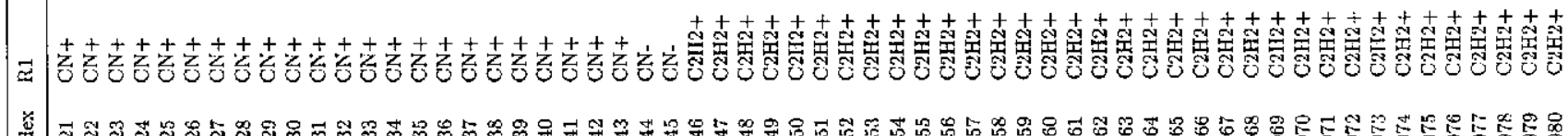

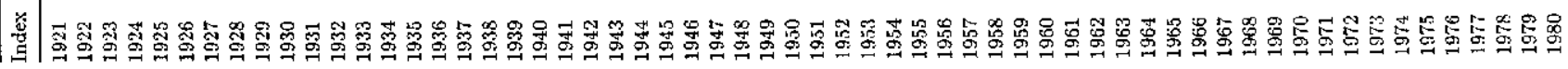


Table 4. continued

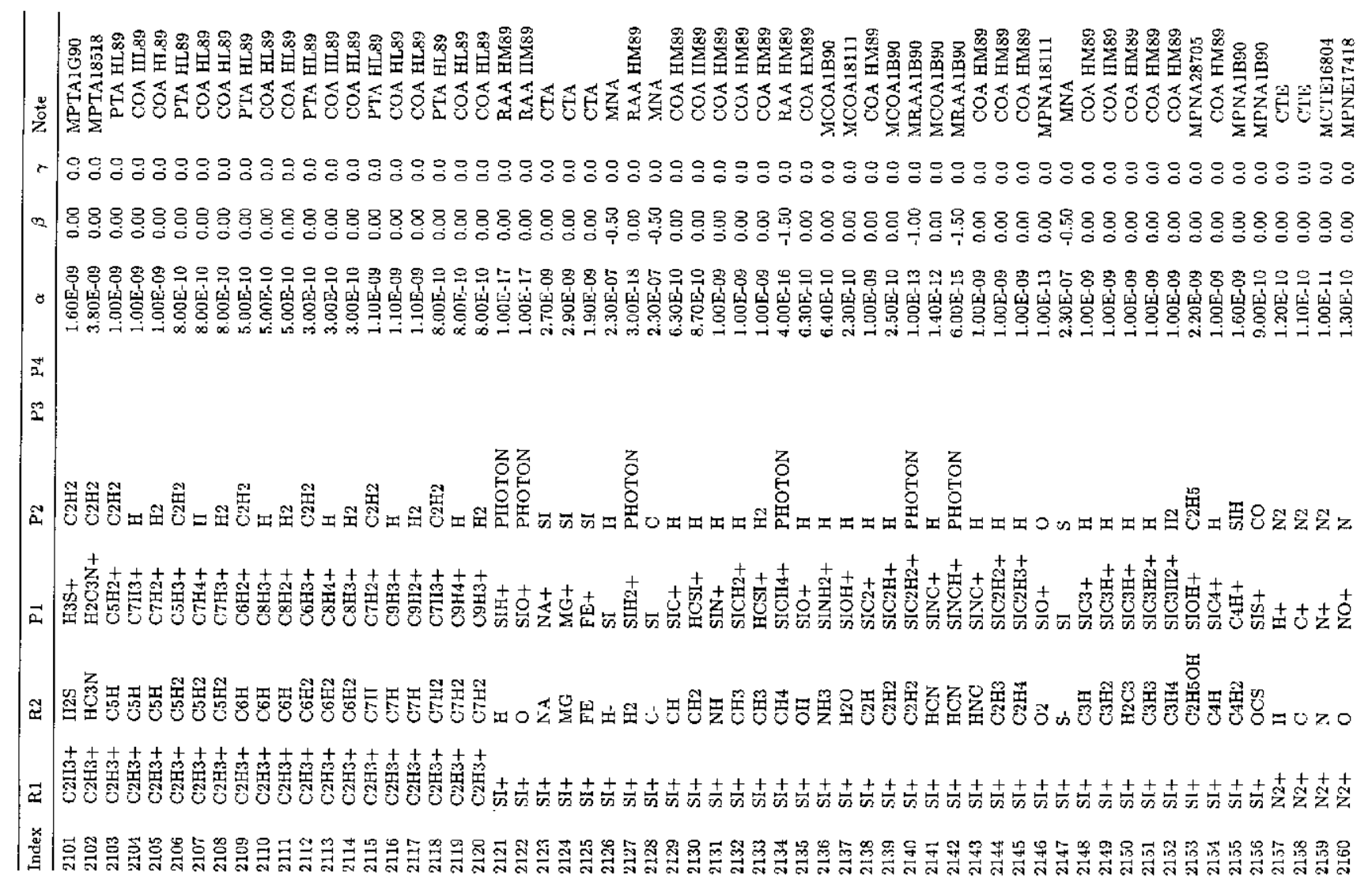

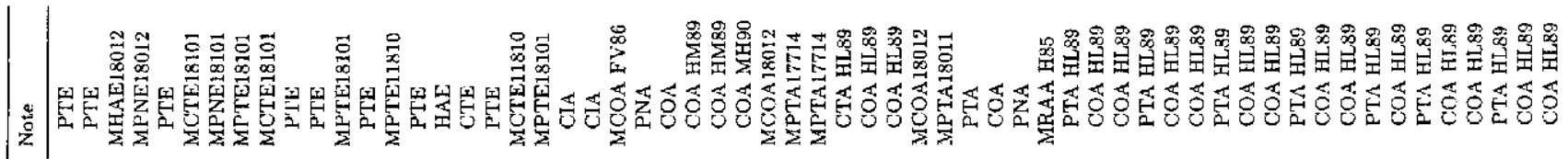

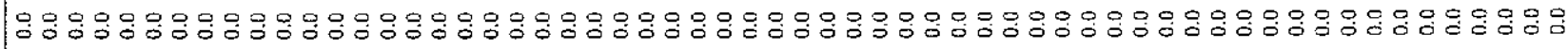

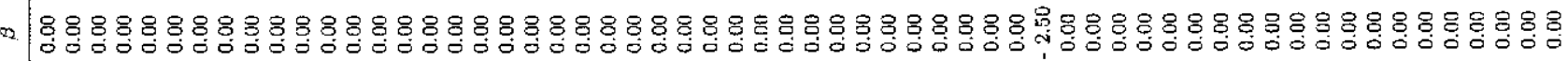

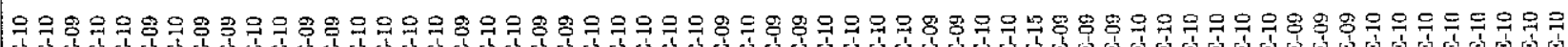

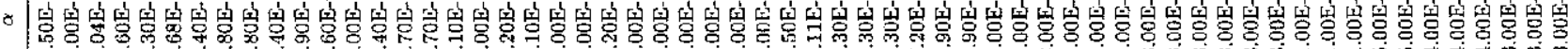

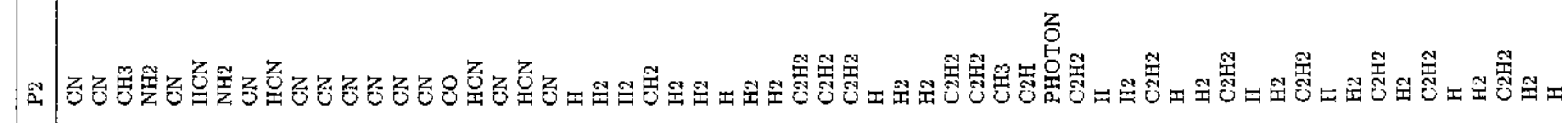

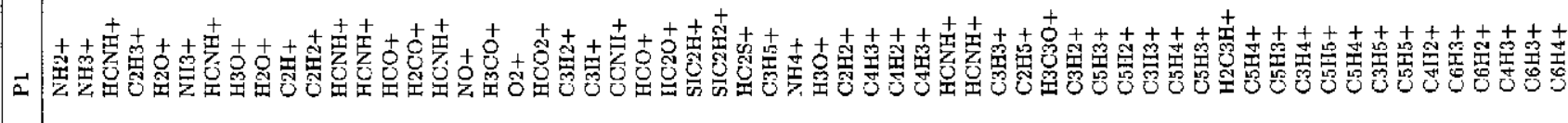

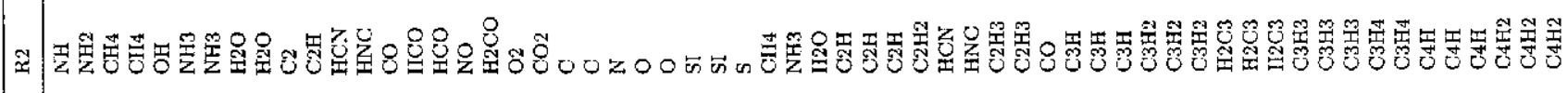

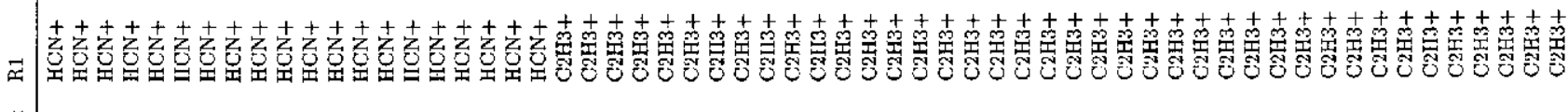

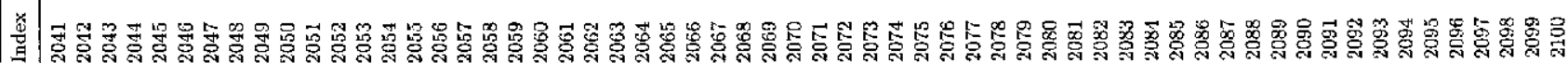


Table 4. continued

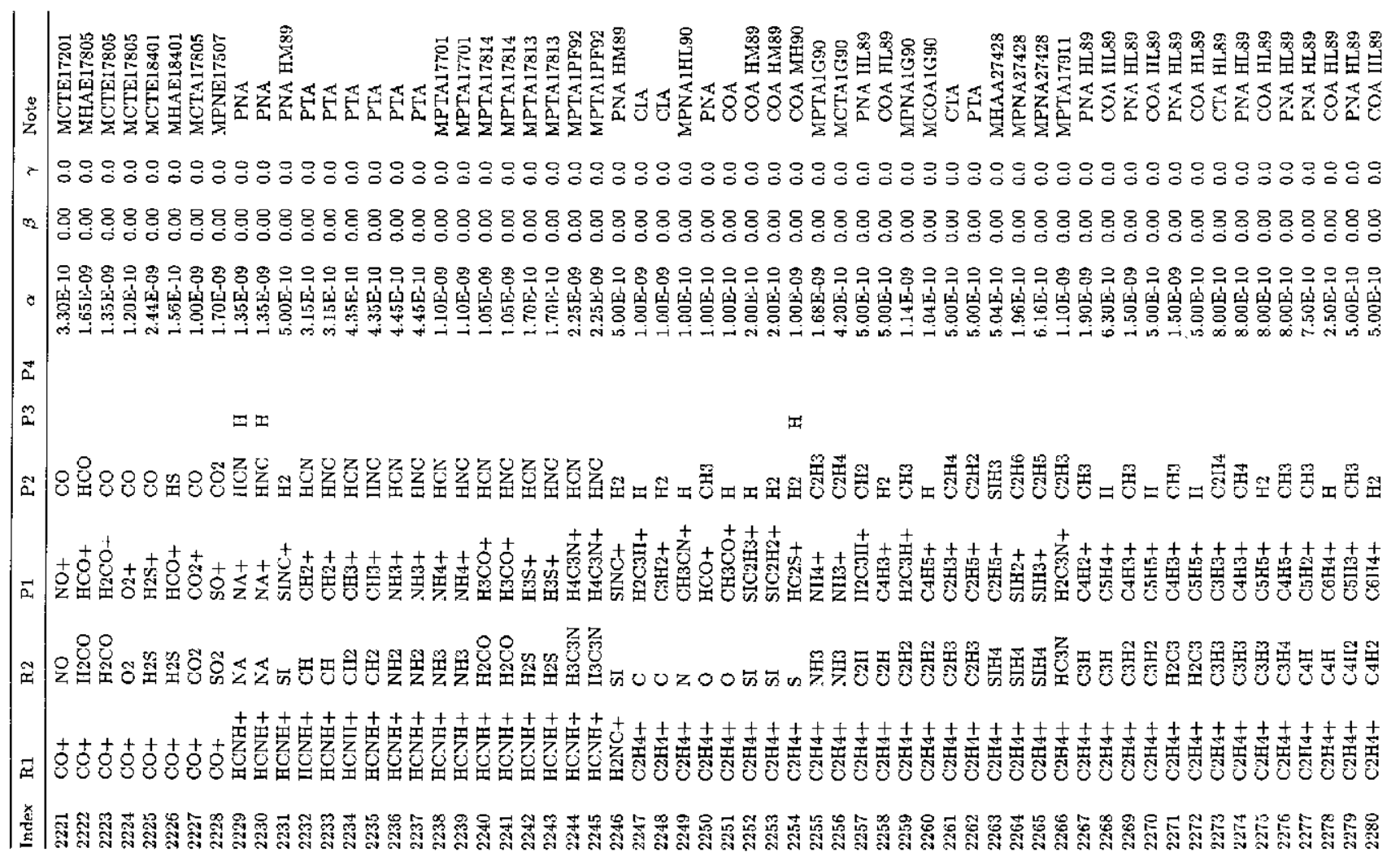

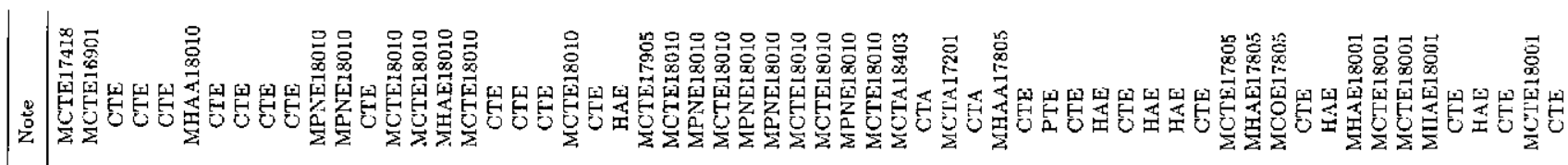

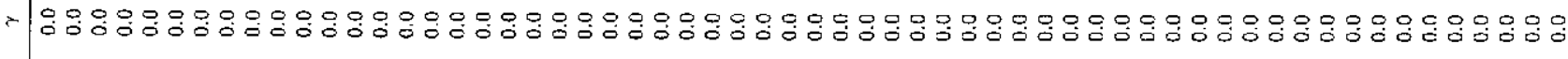

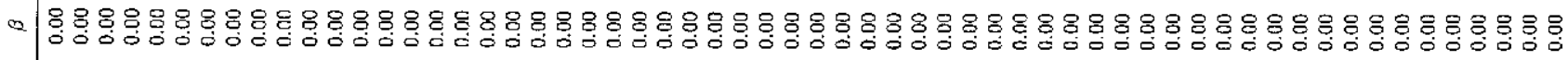

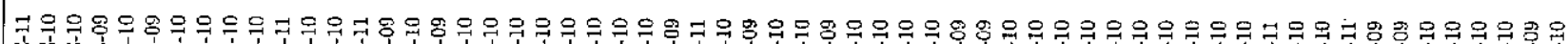

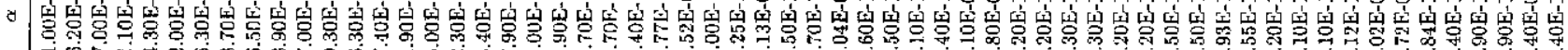
艺

zิ x

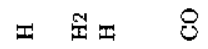

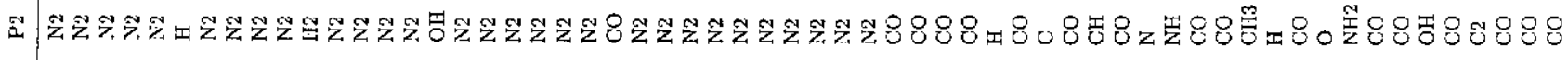

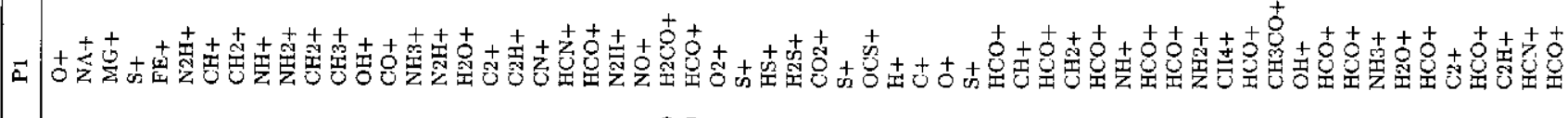

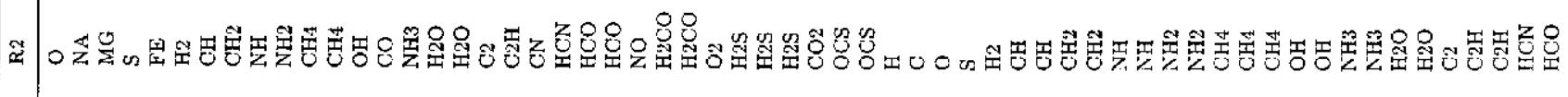

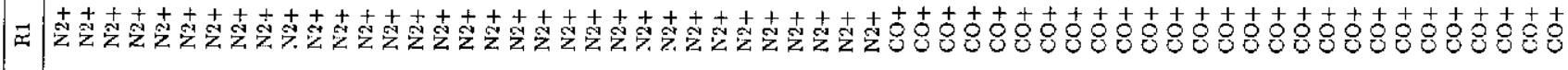

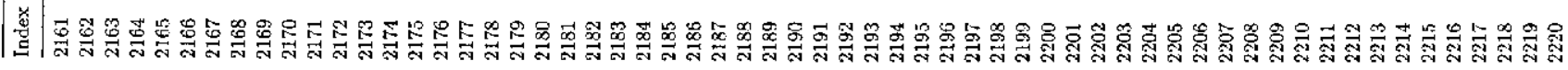


Table 4. continued

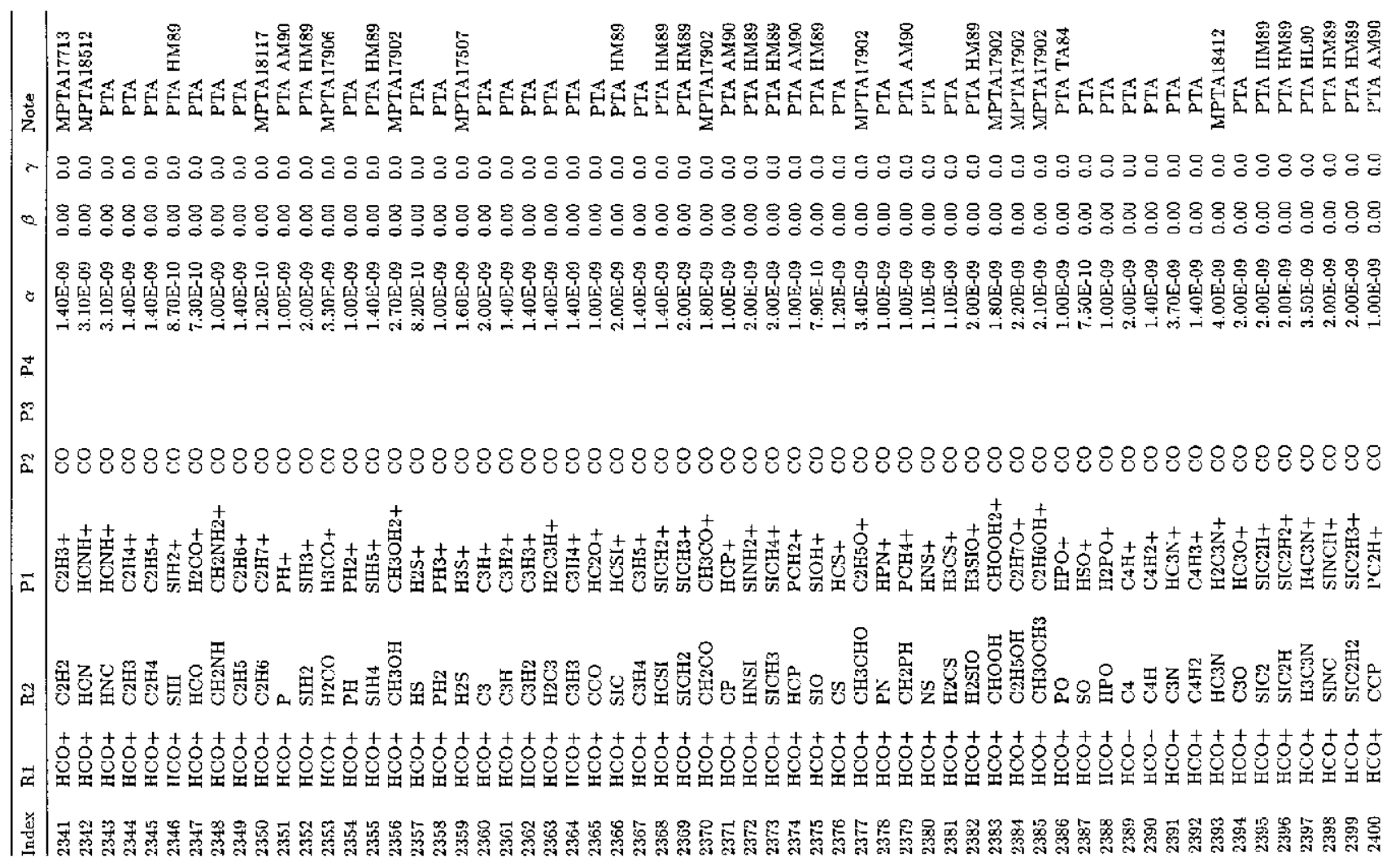

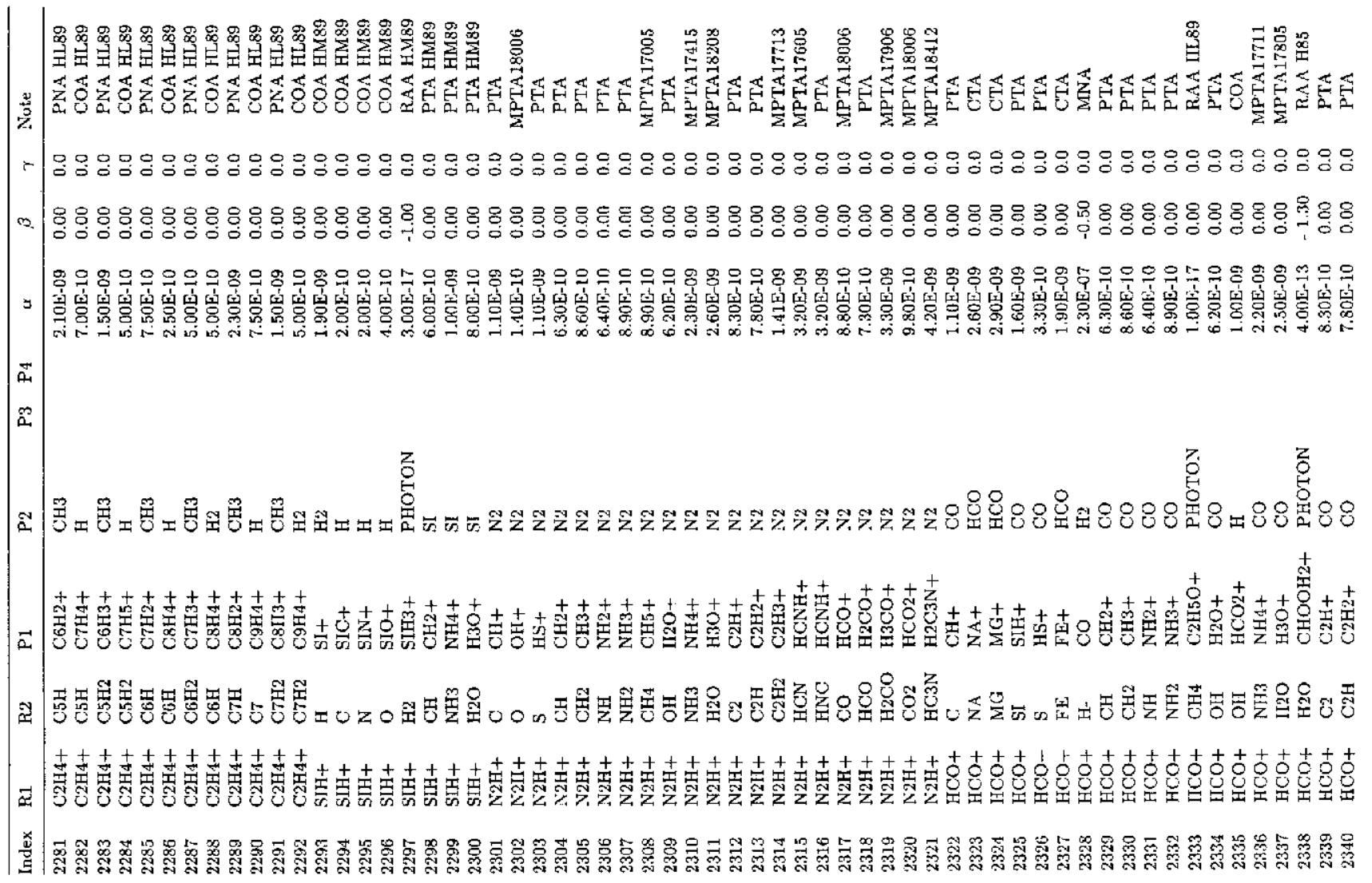


Table 4. continued

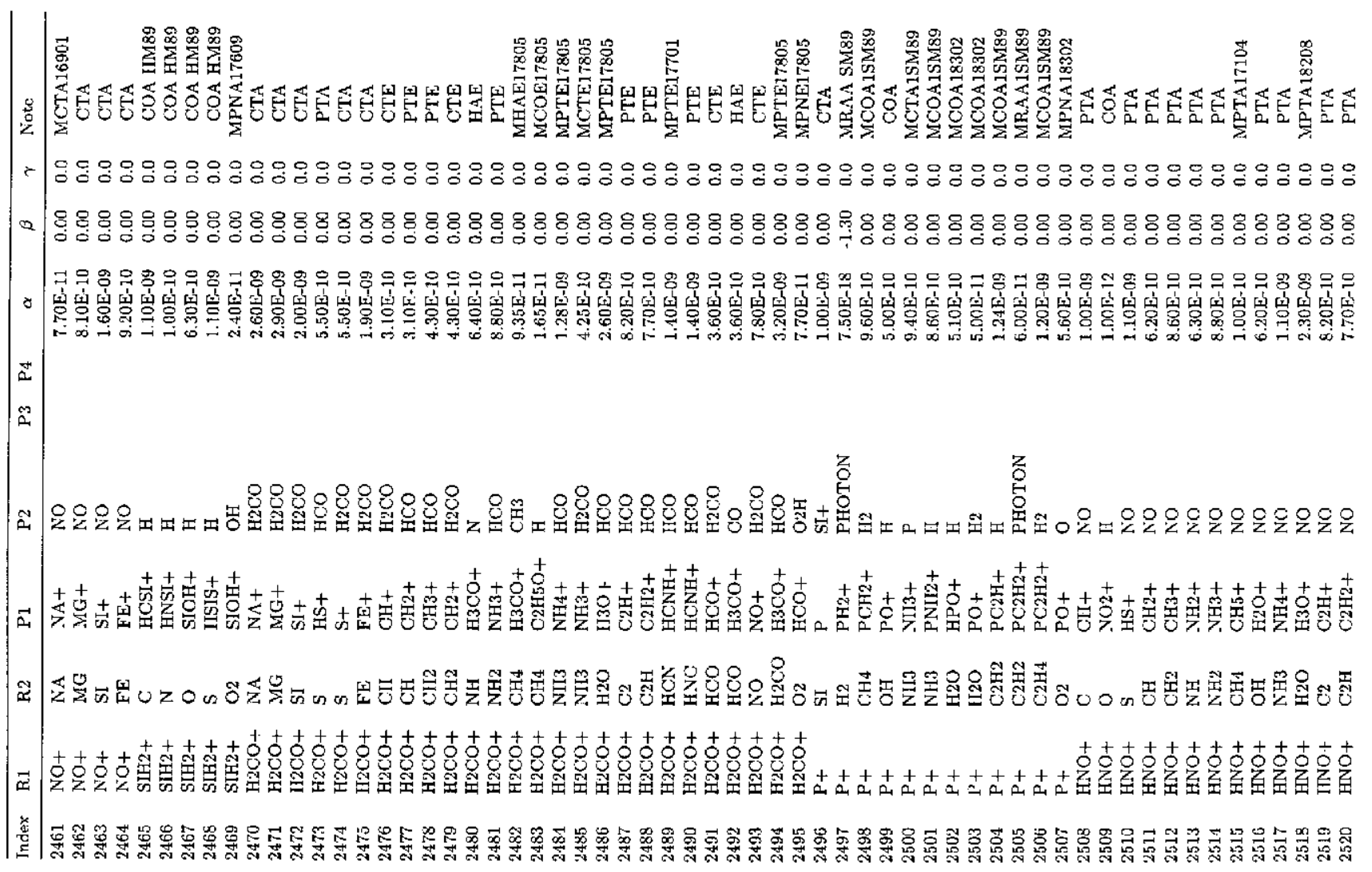

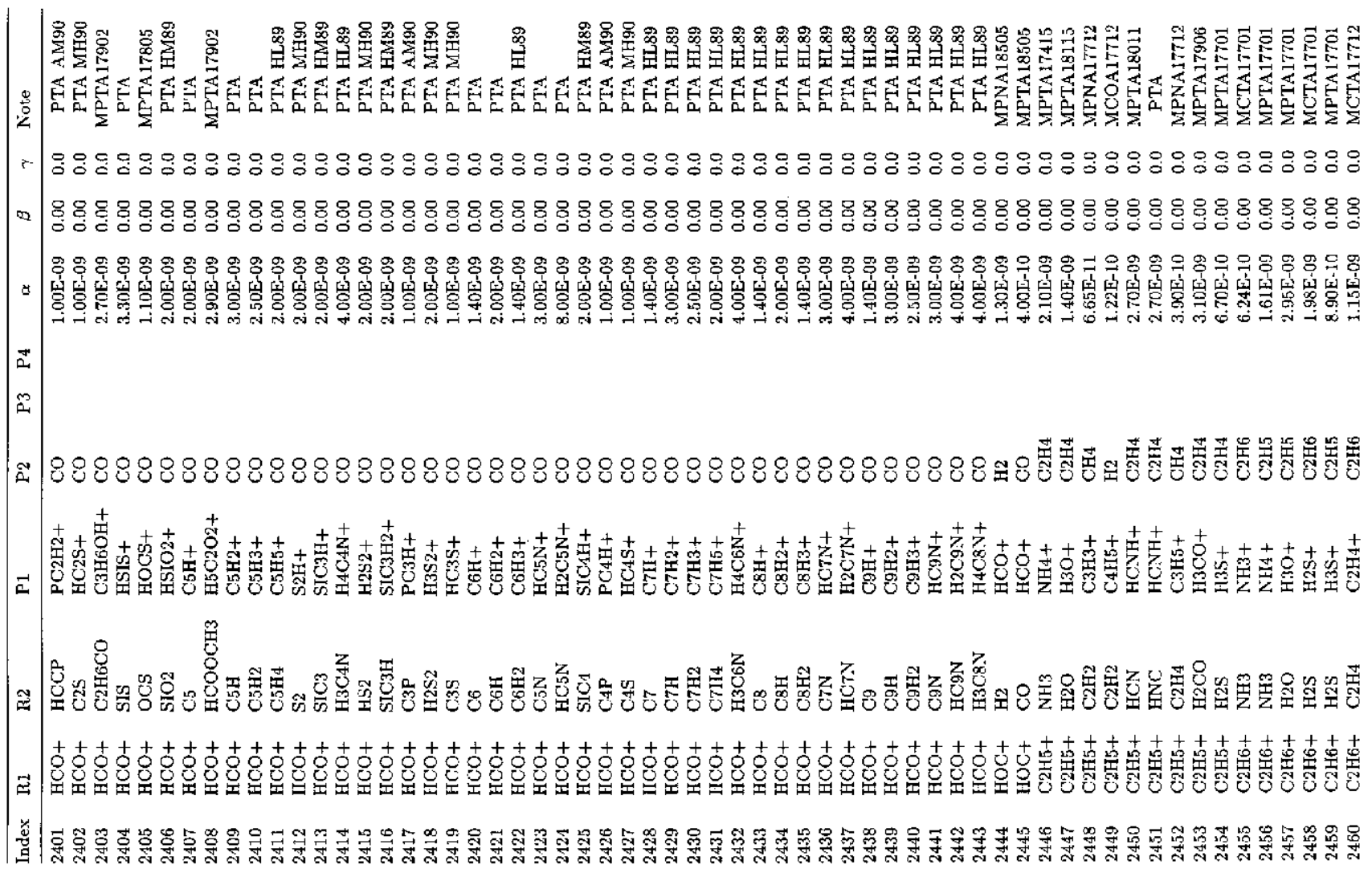


Table 4. continued

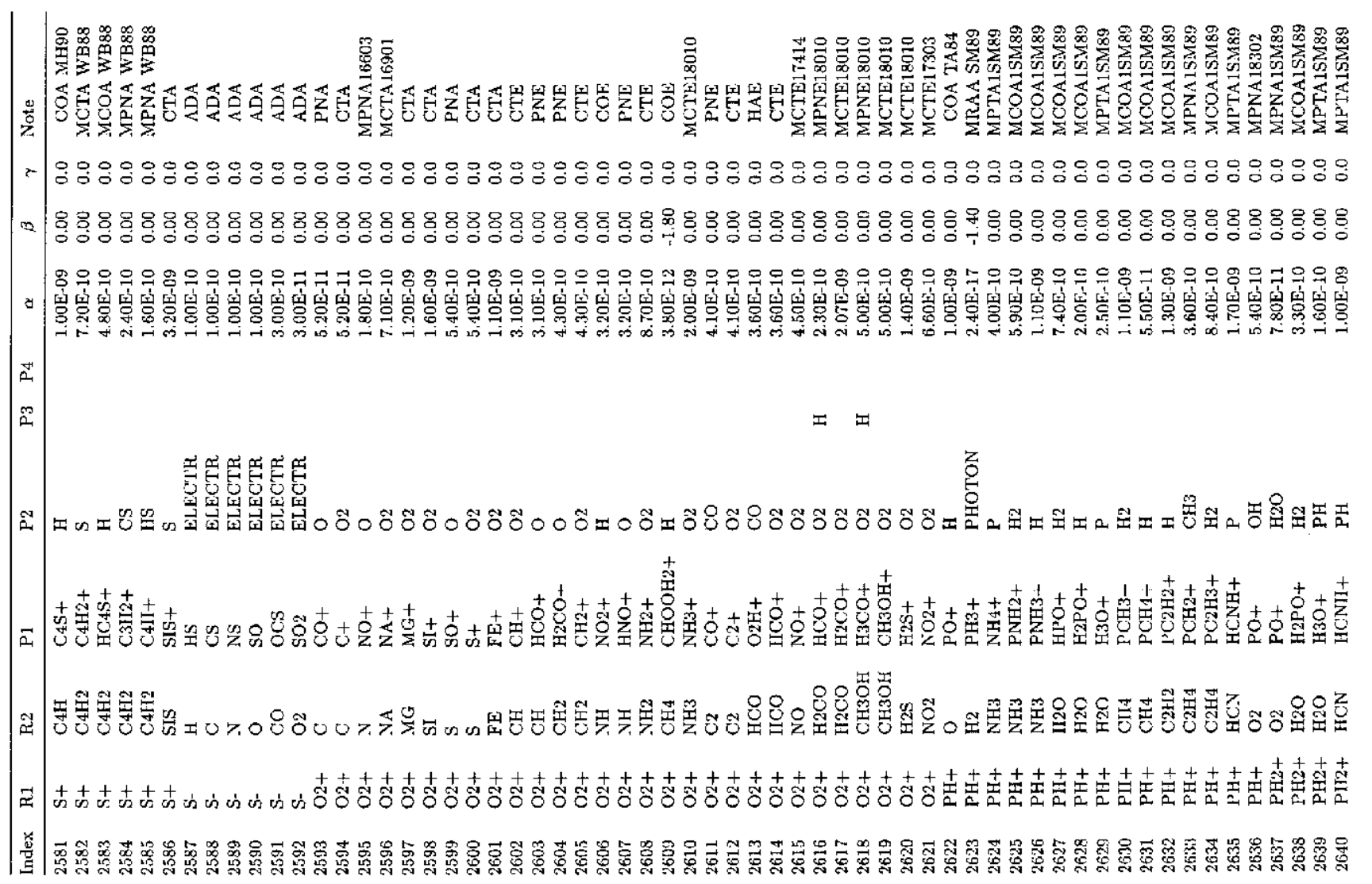

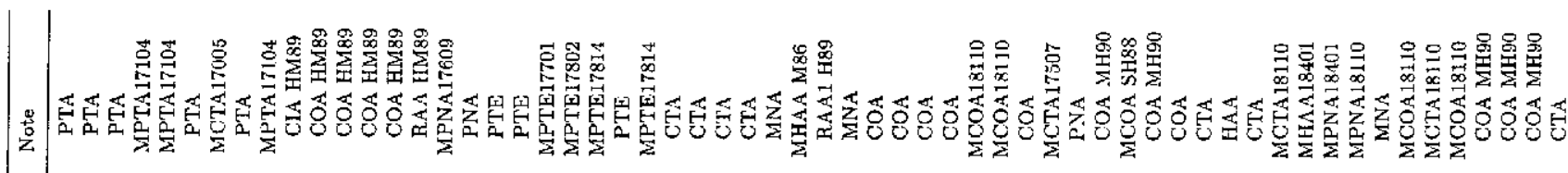

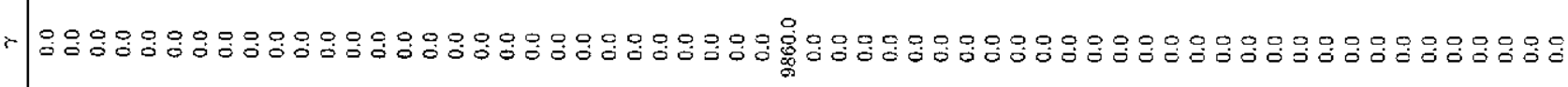

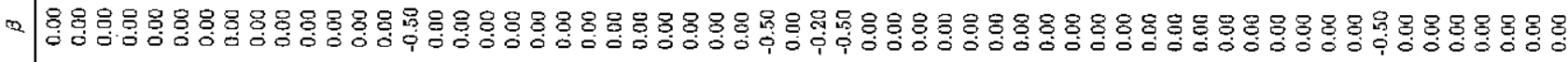

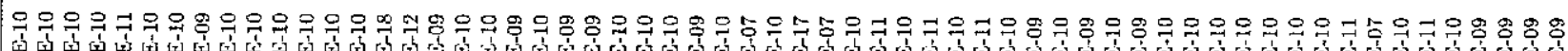

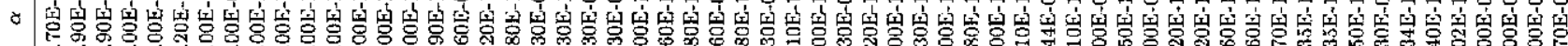

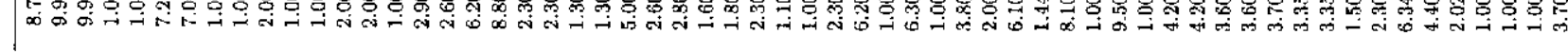

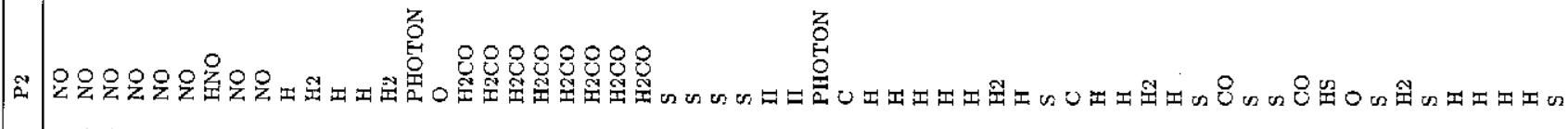

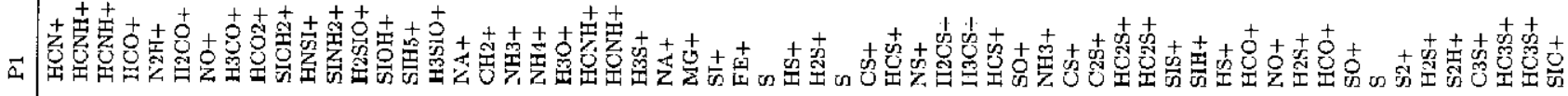

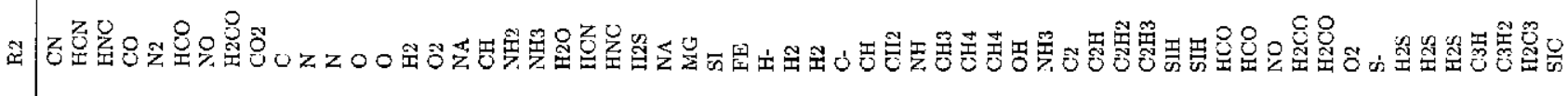

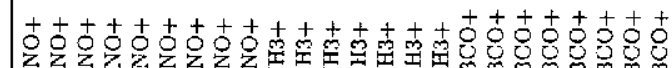

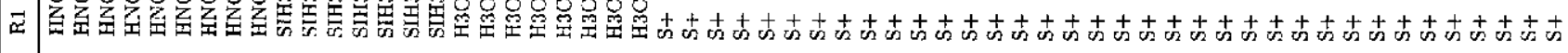

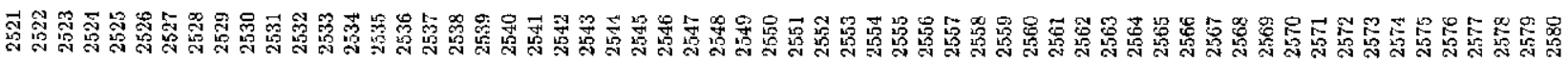


Table 4. continued

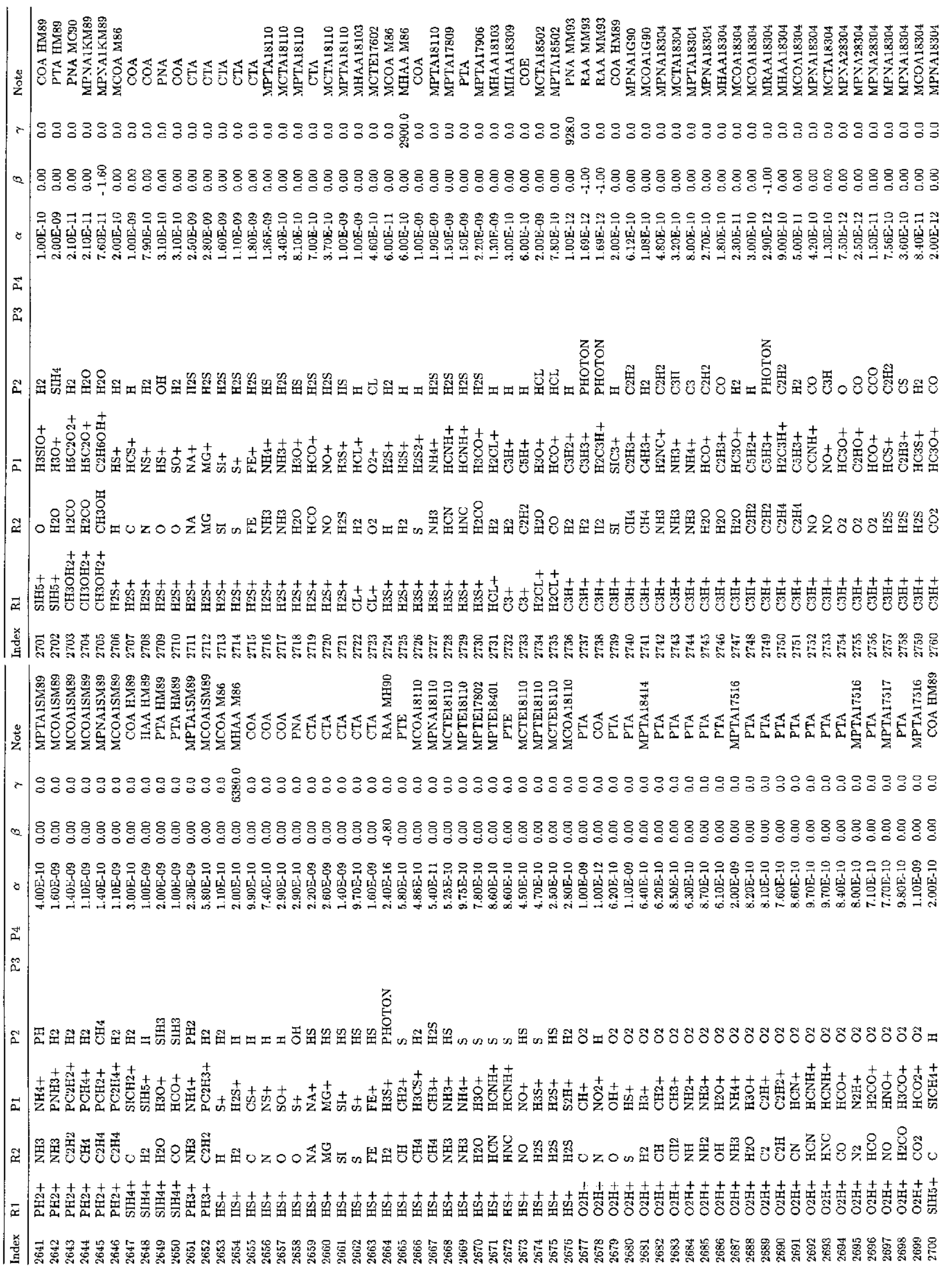


Table 4. continued

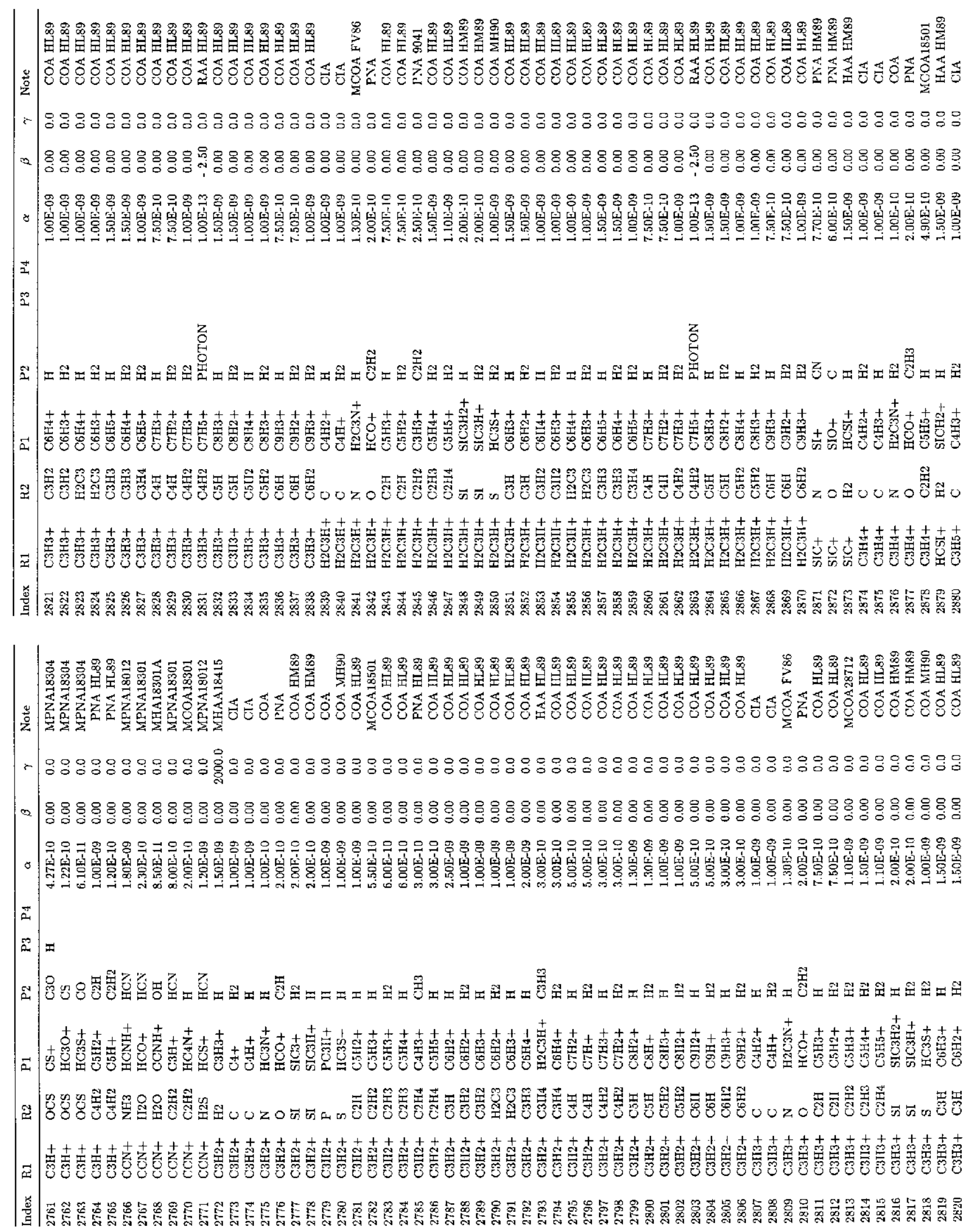


Table 4. continued
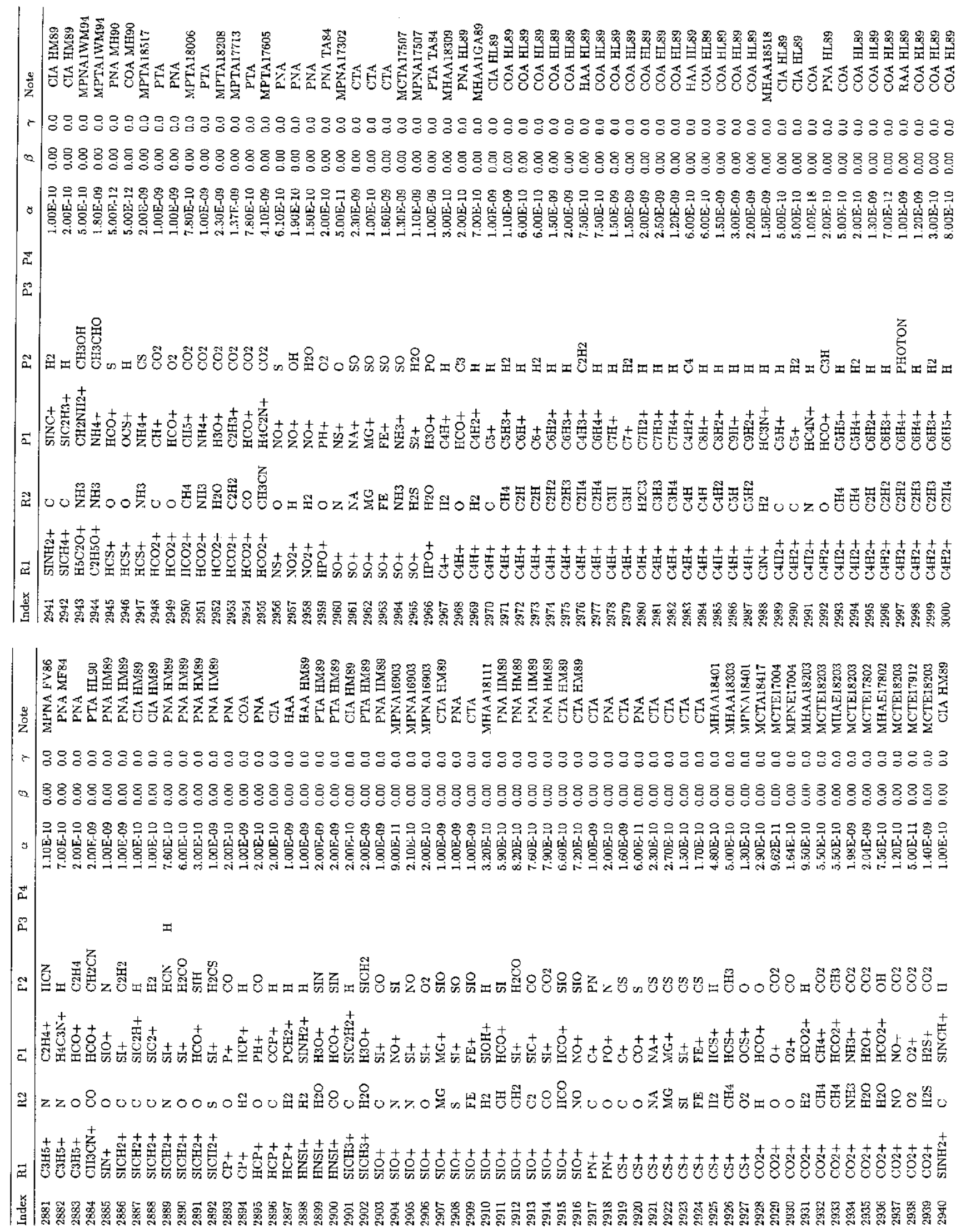
Table 4. continued

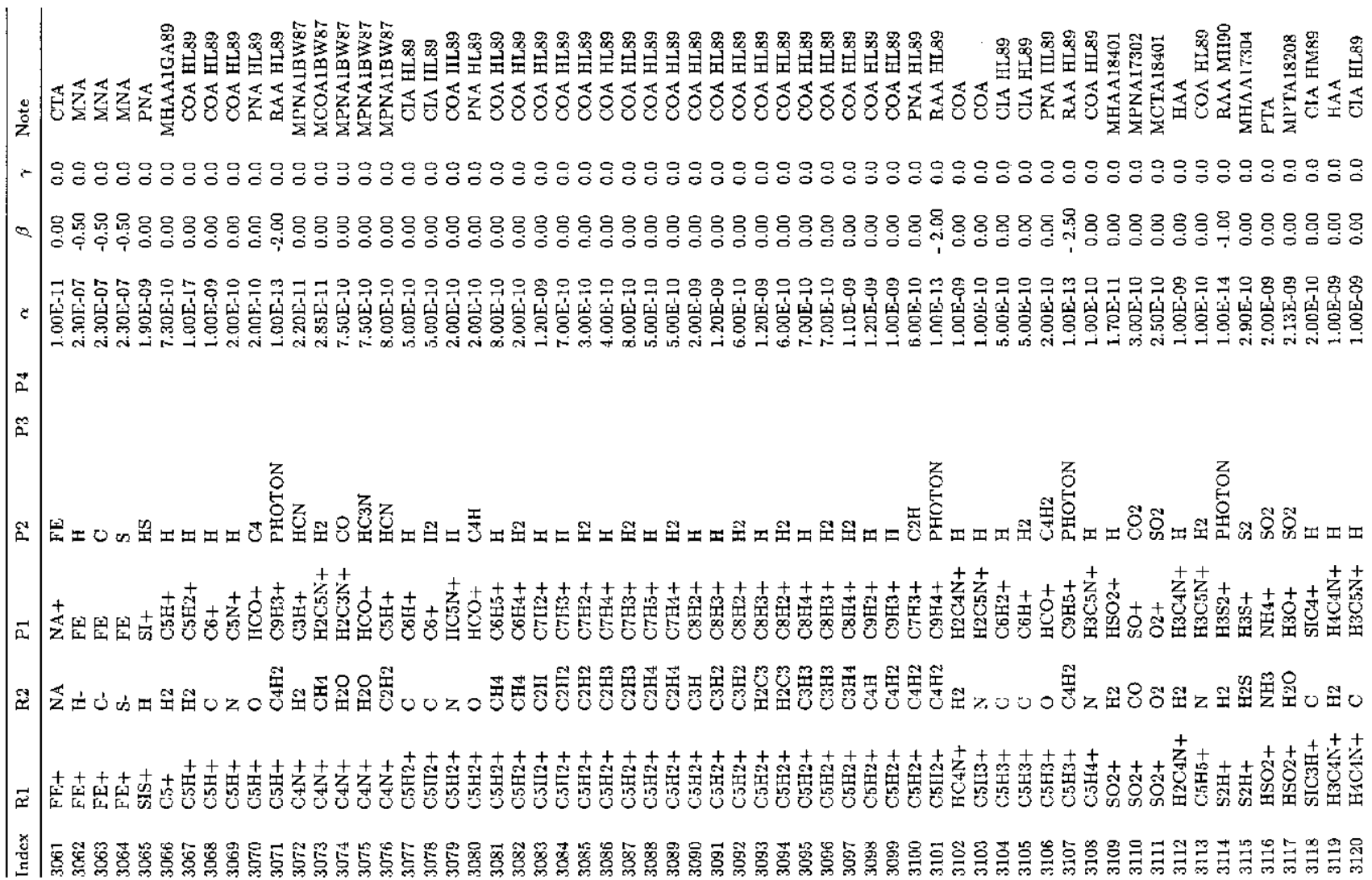

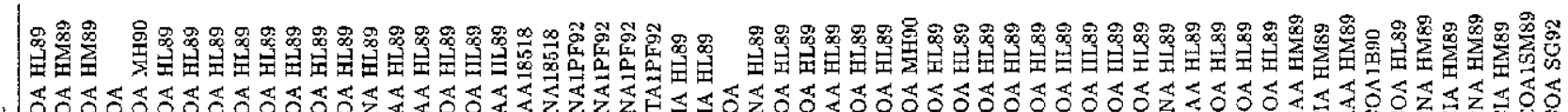

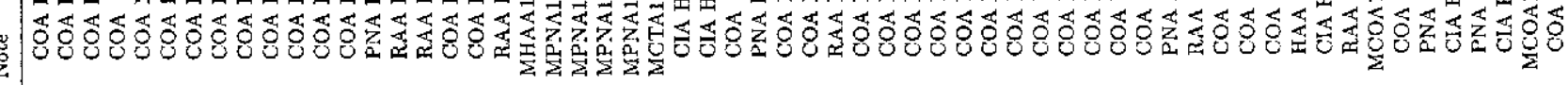

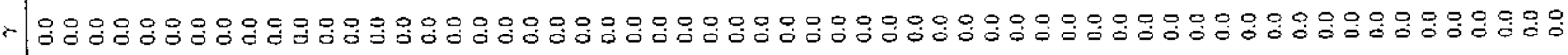

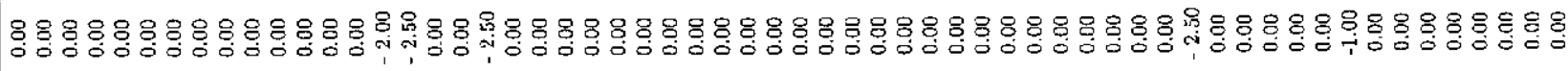

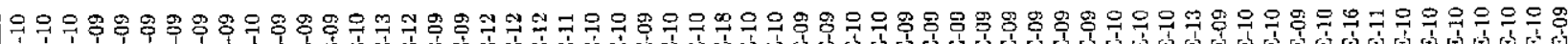

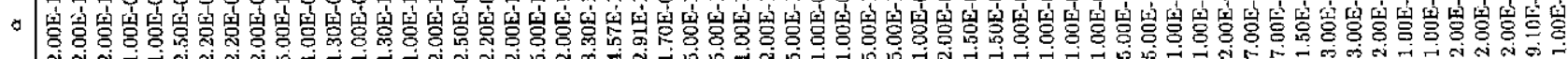
茫

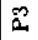

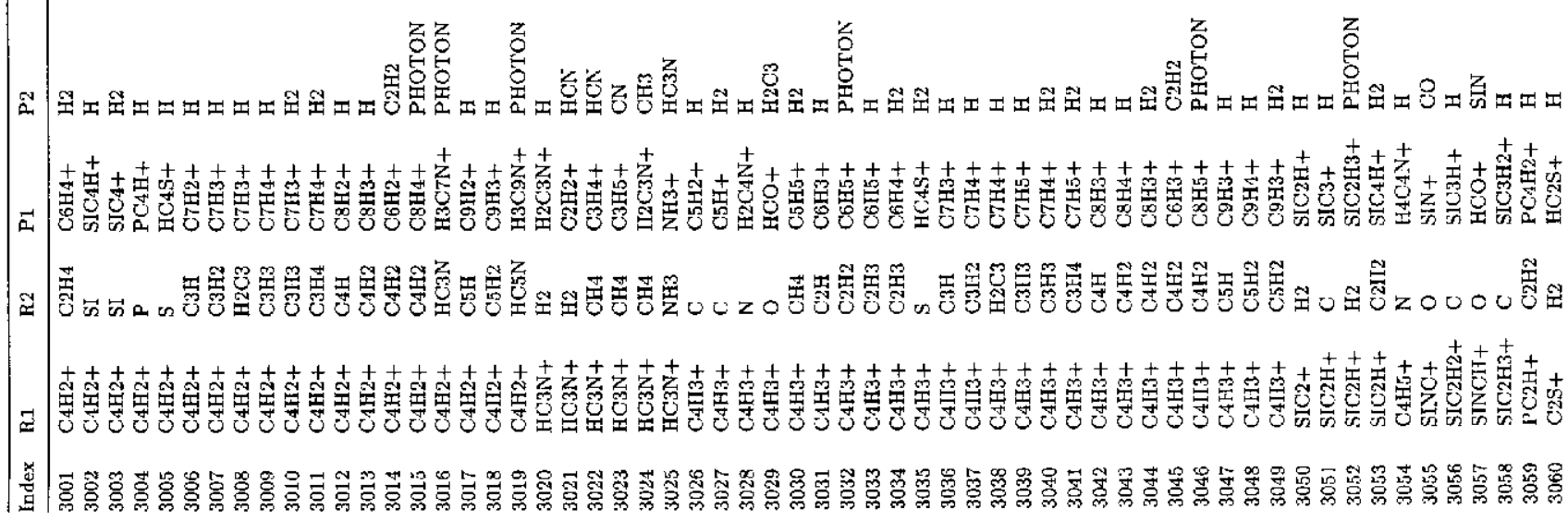


Table 4. continued

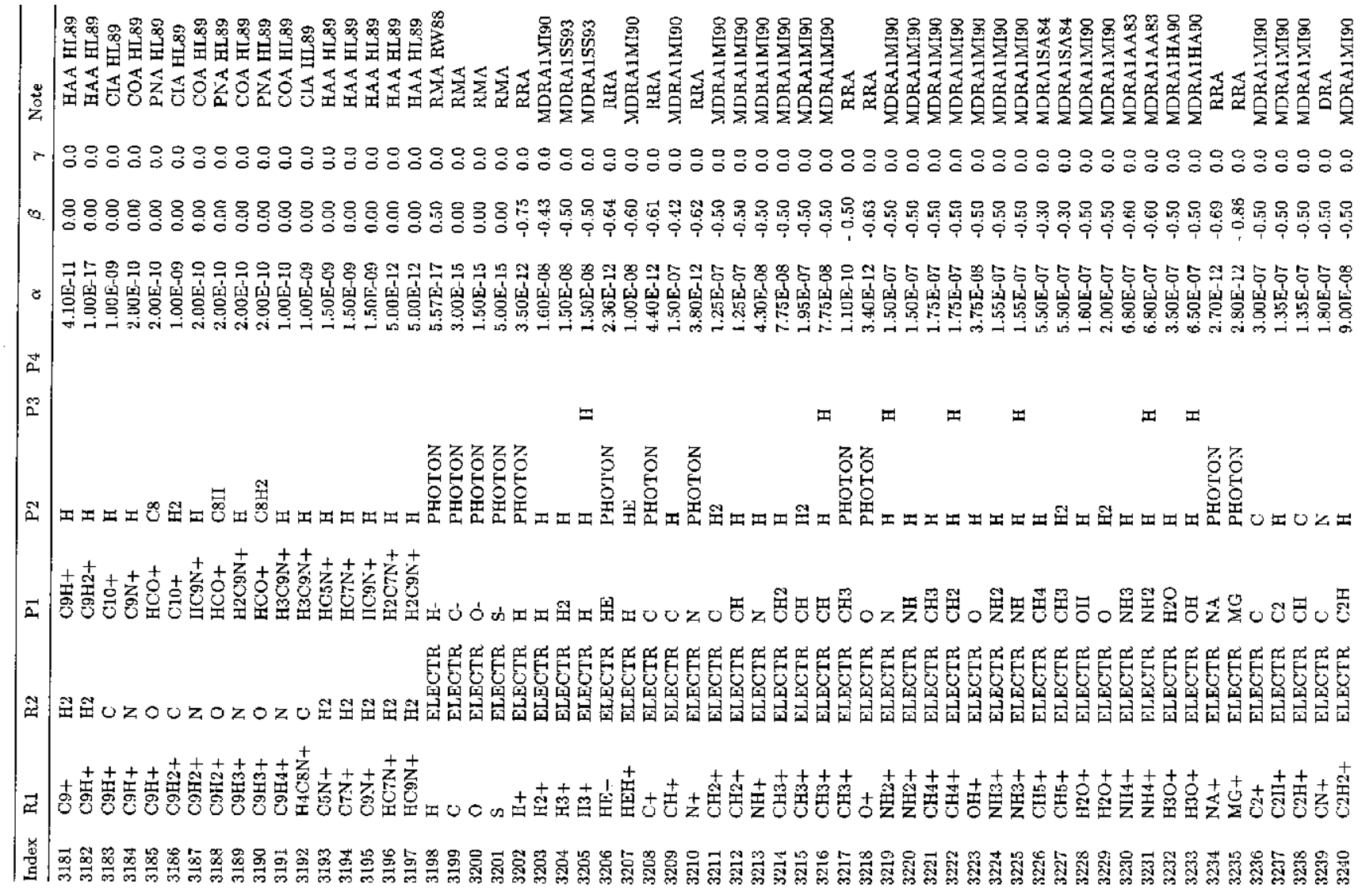

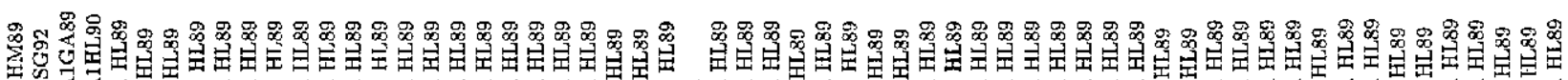

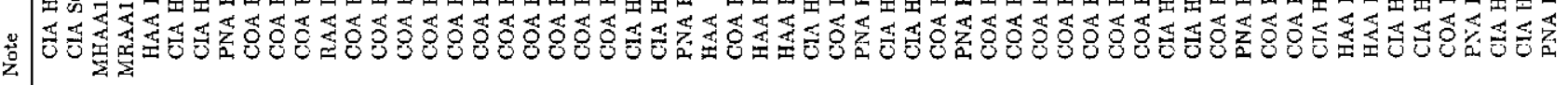

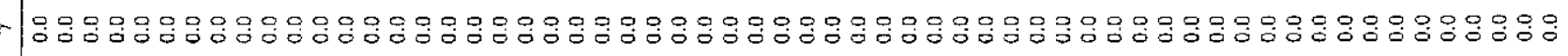

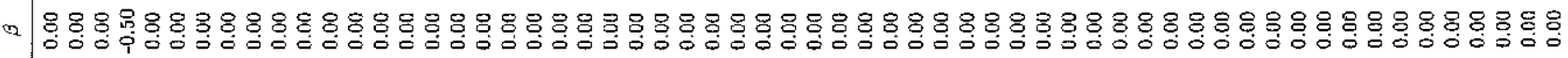

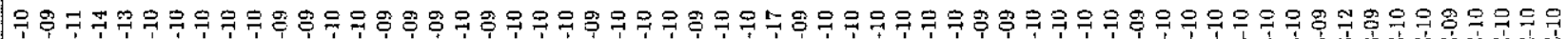

ه

茫

$\cong$

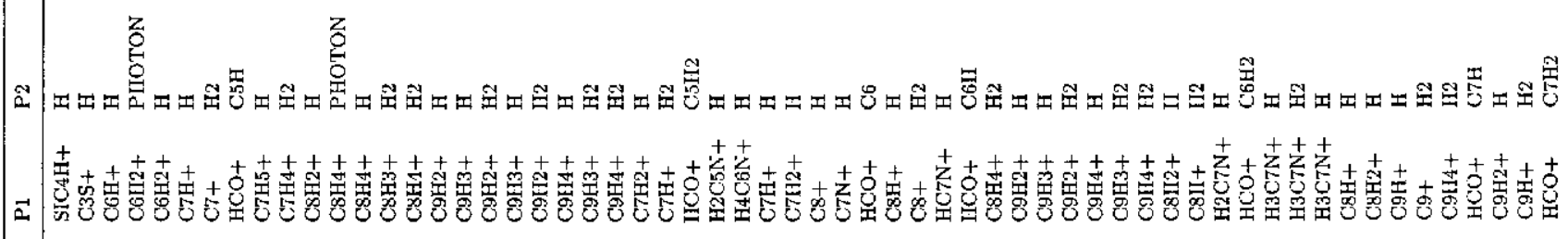

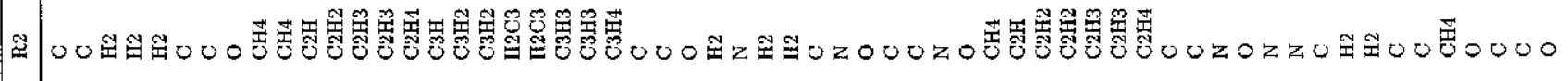

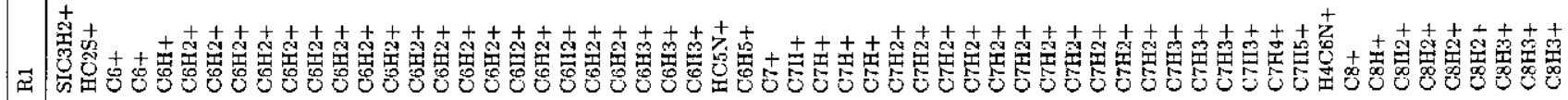

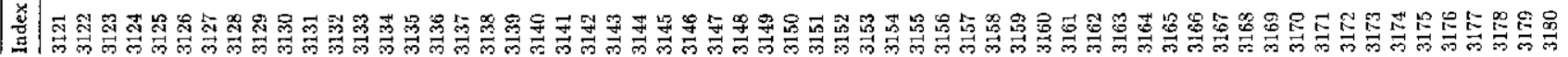


Table 4. continued

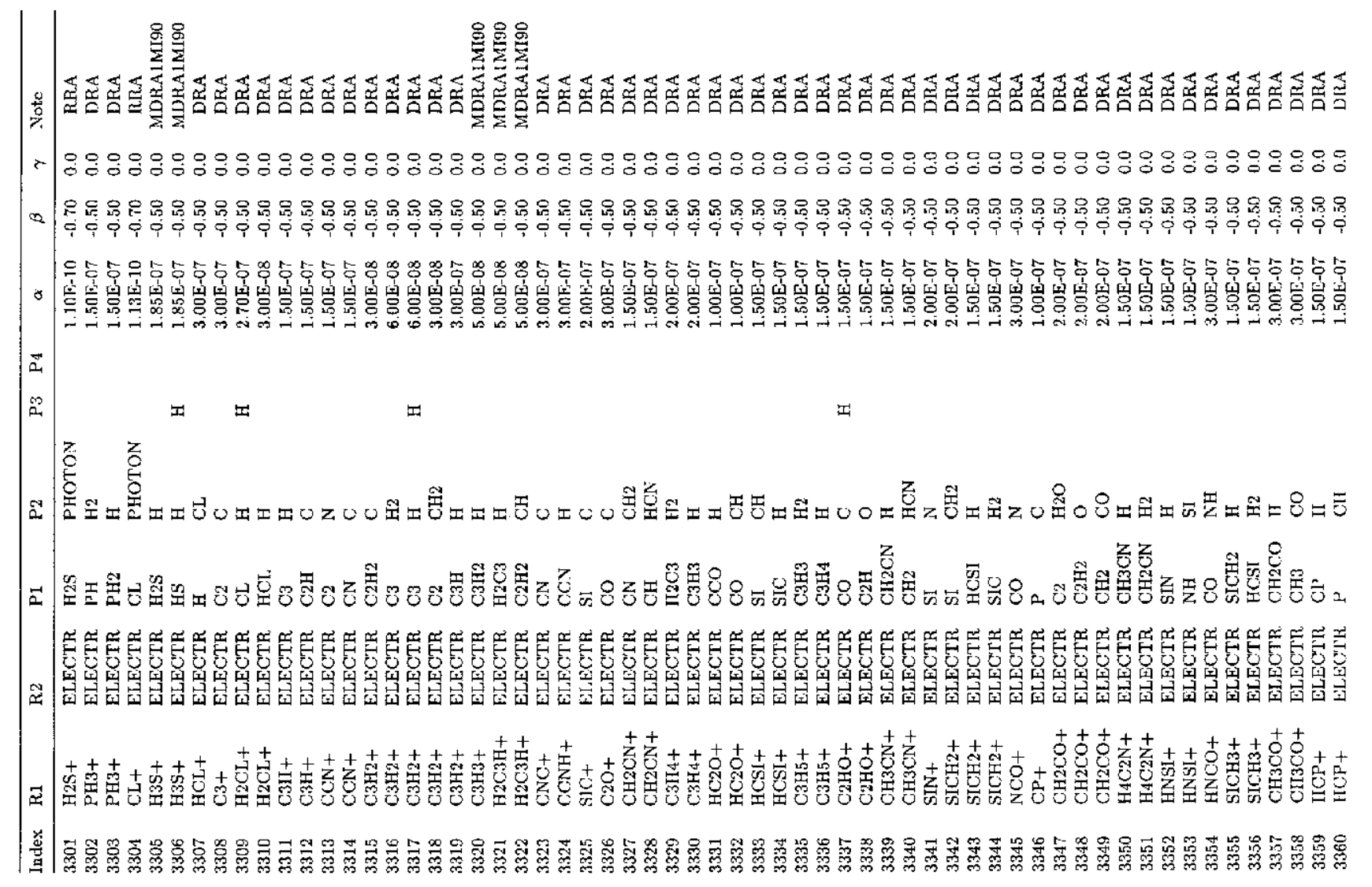

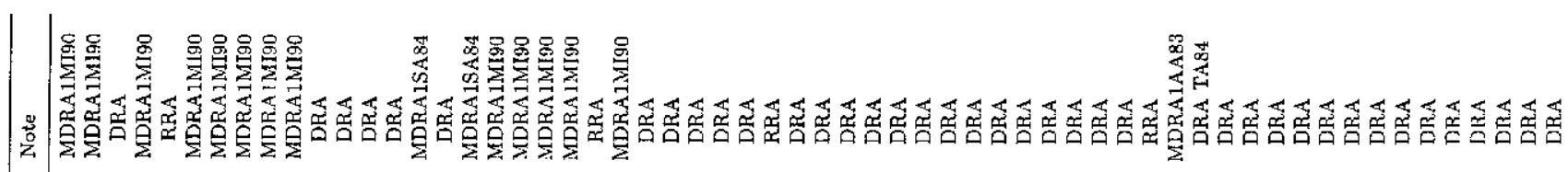

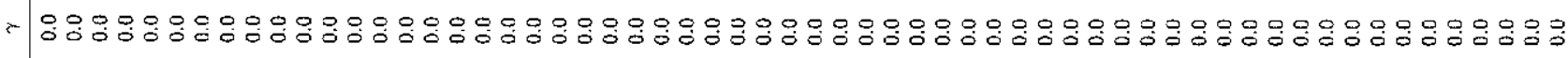

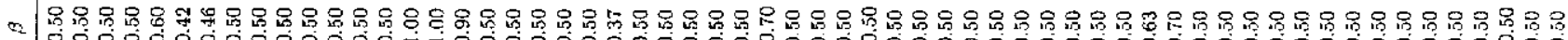

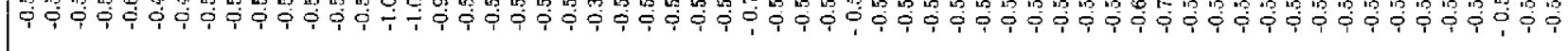

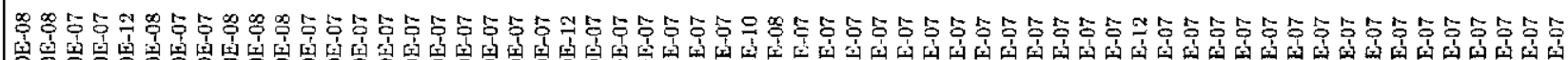

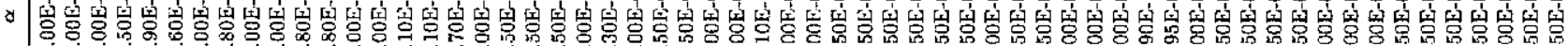
莎

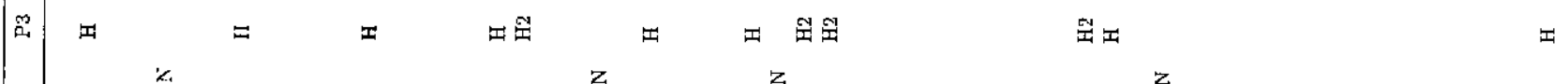

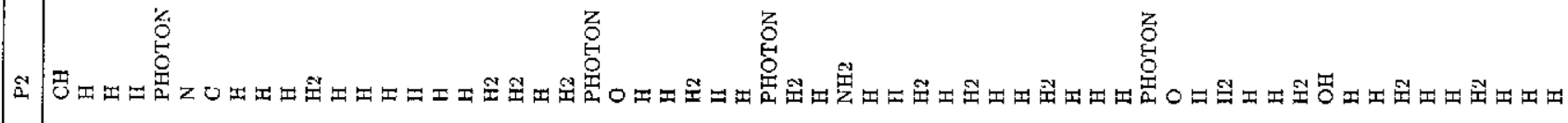

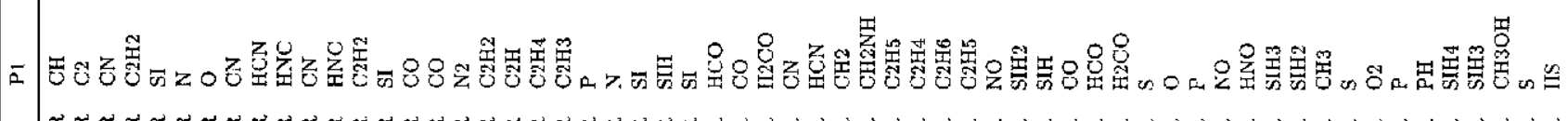

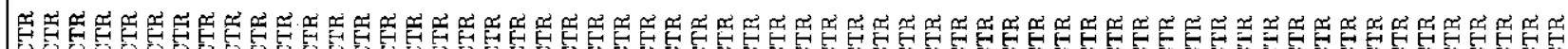

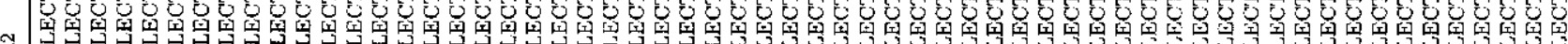

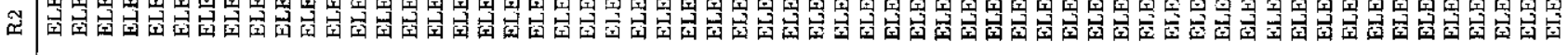

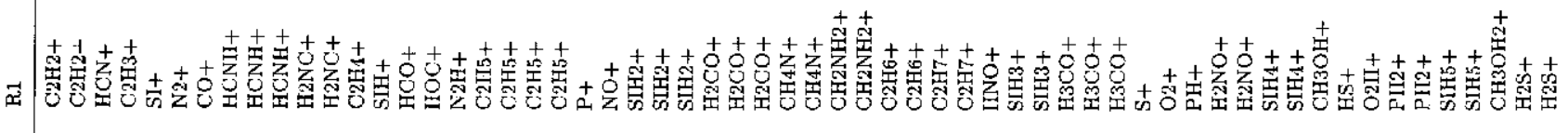

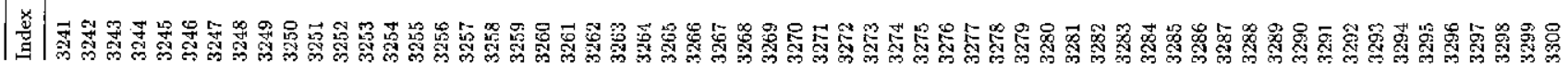


Table 4. continued

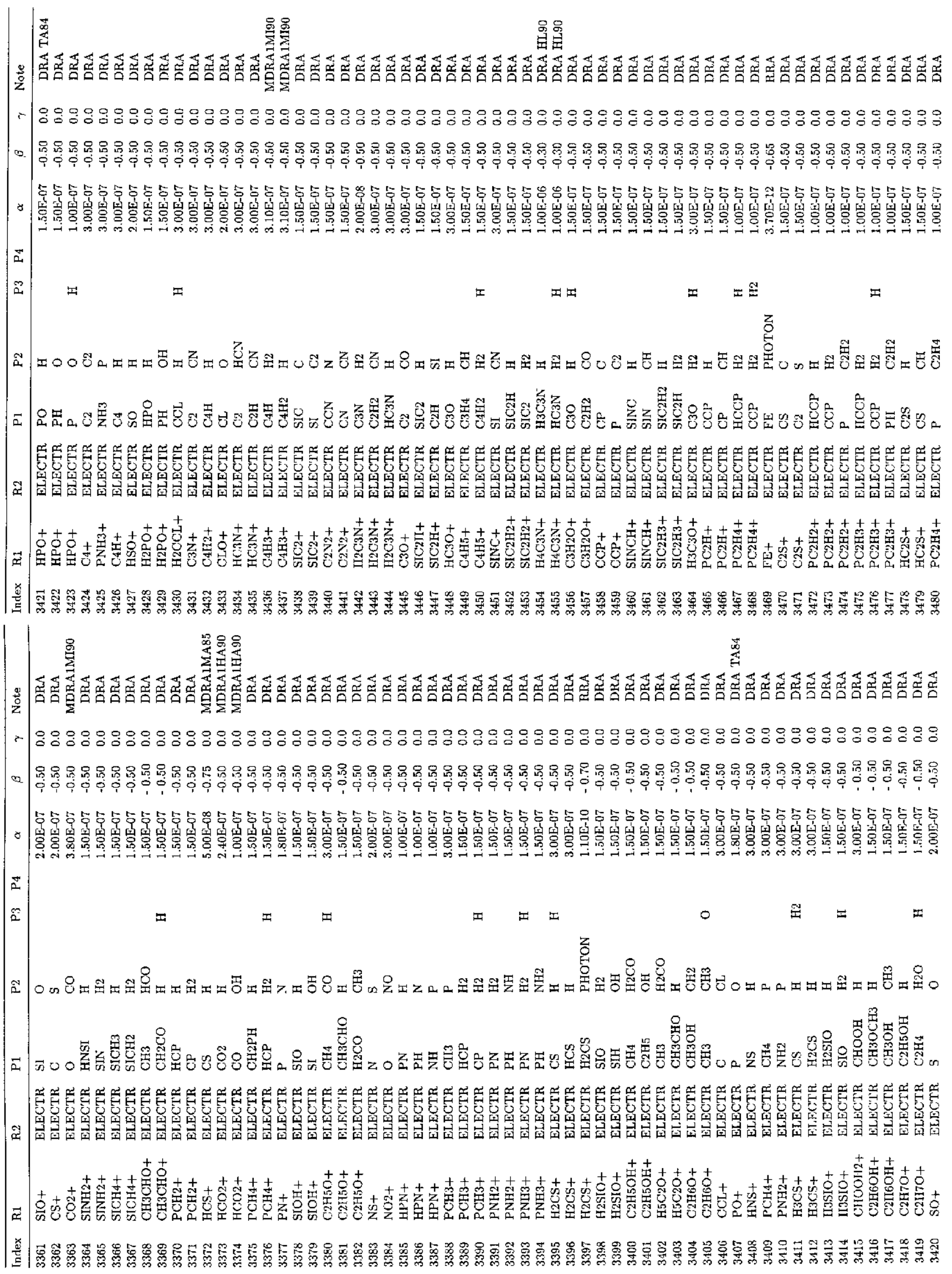


Table 4. continued

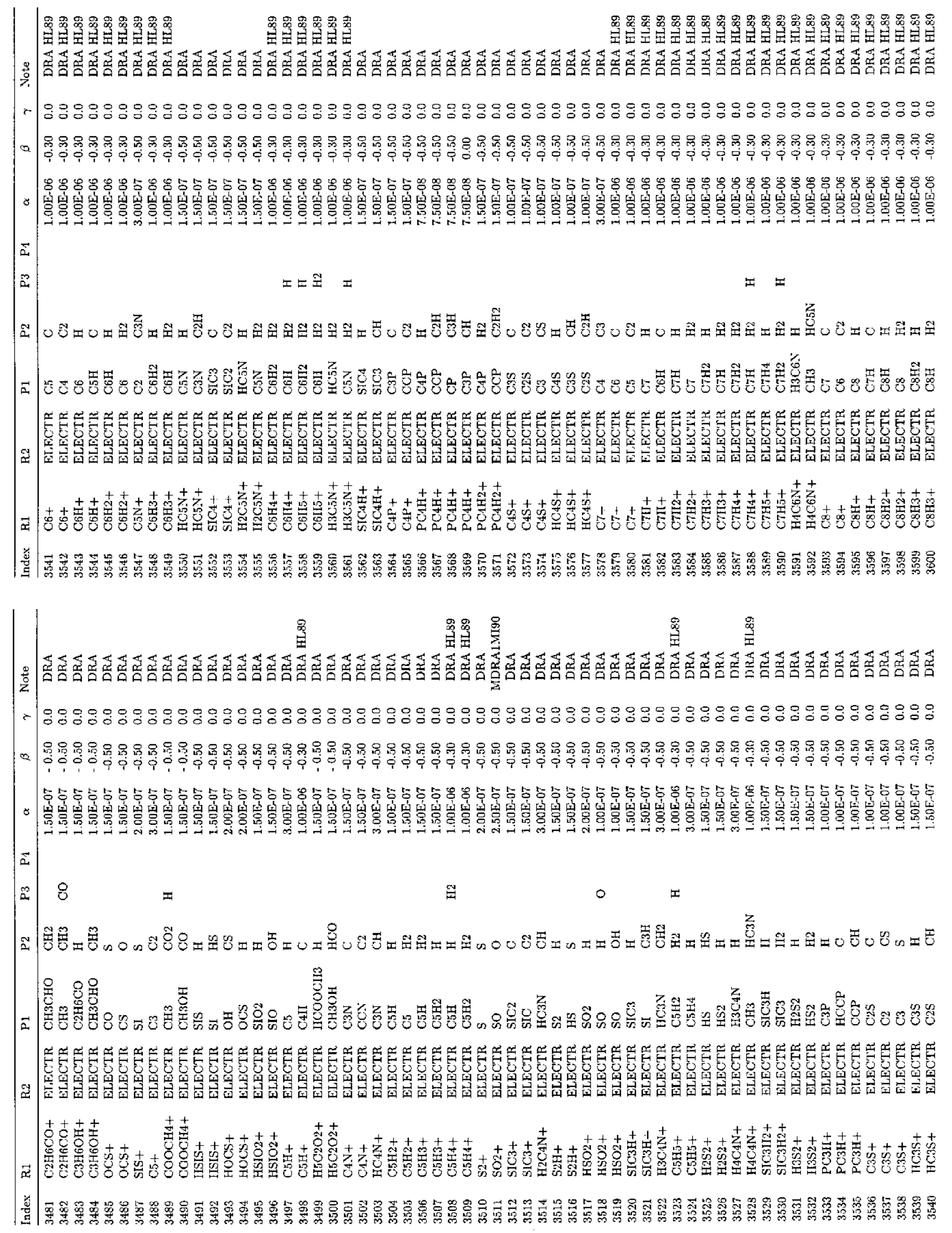


Table 4. continued

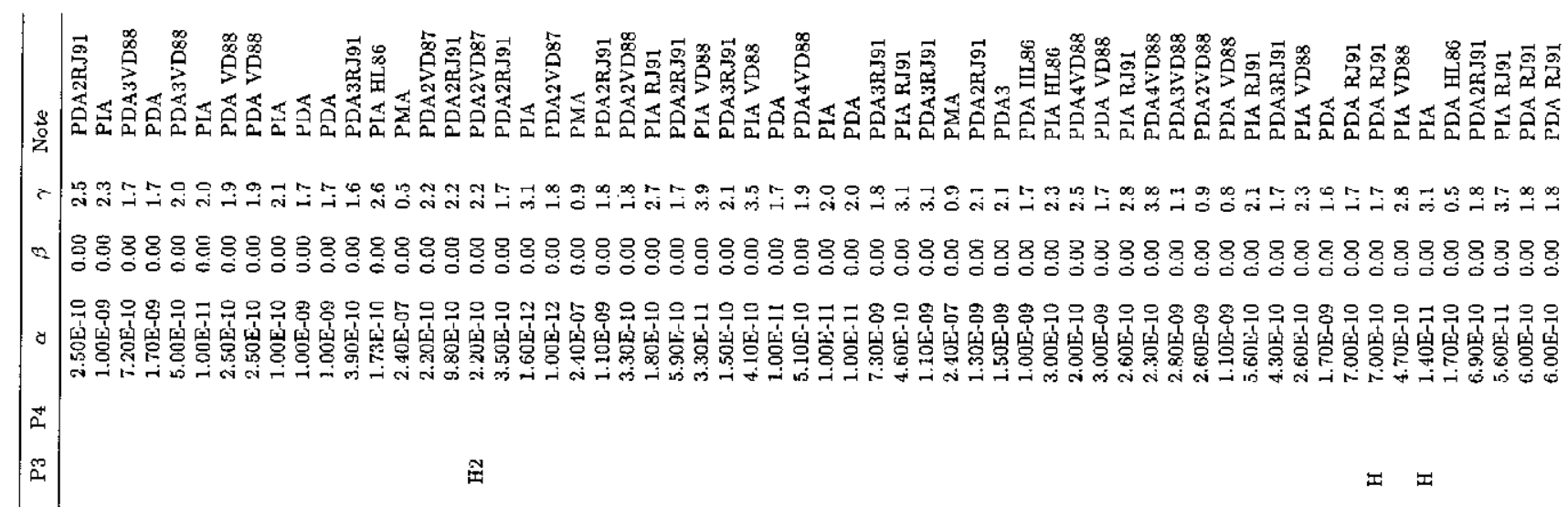

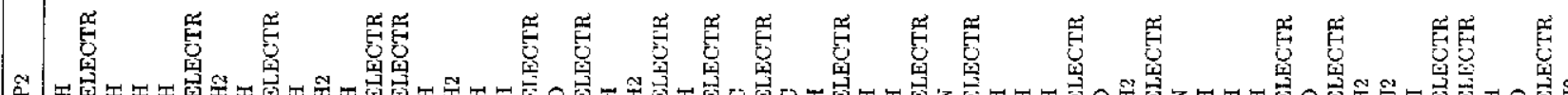

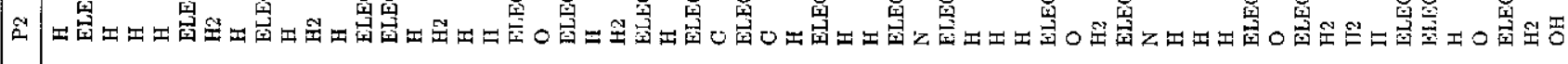

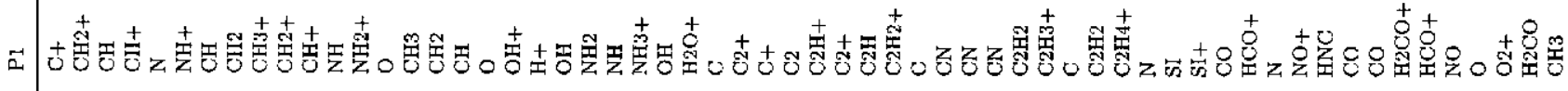

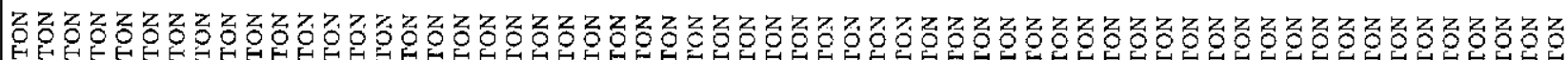

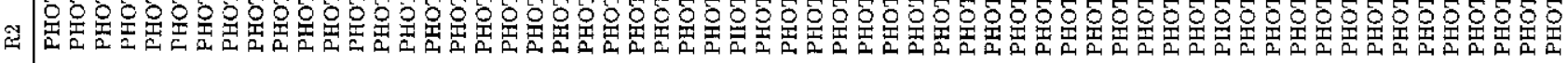

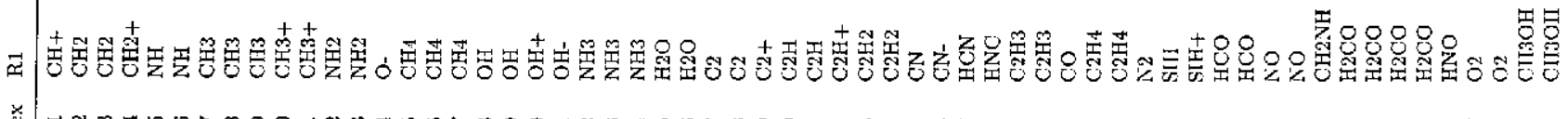

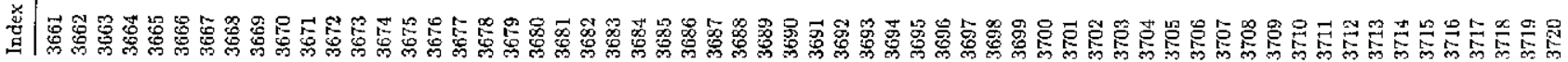

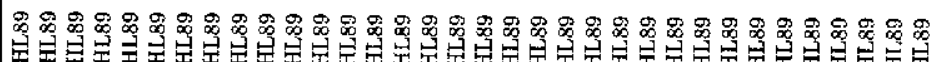

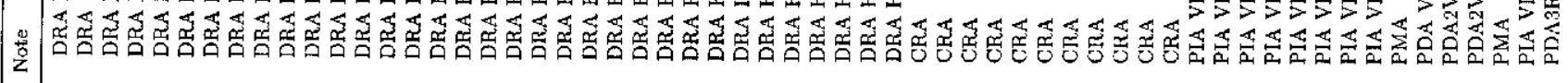

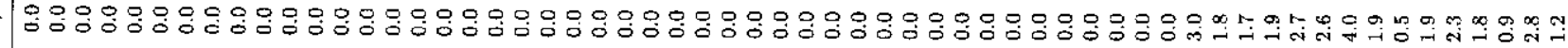

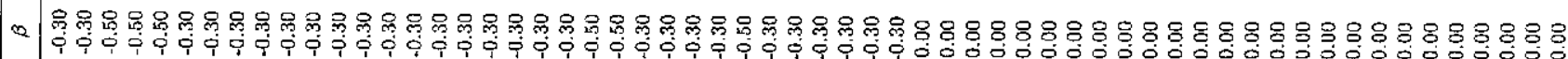

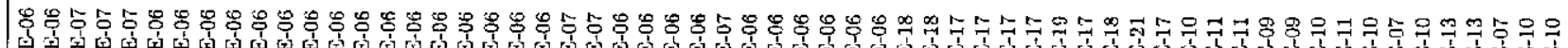

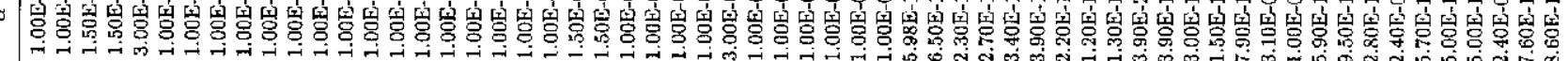

$\ddot{2}$

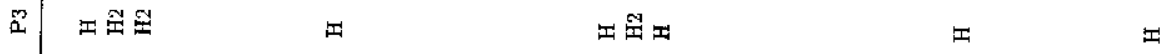

준

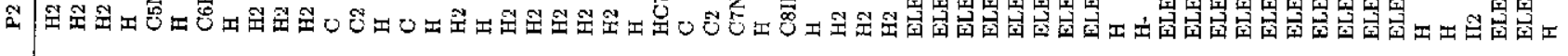

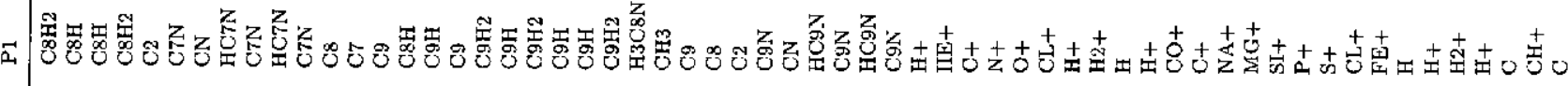

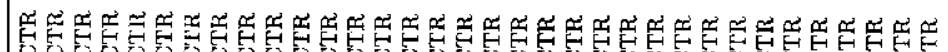

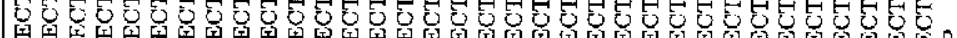

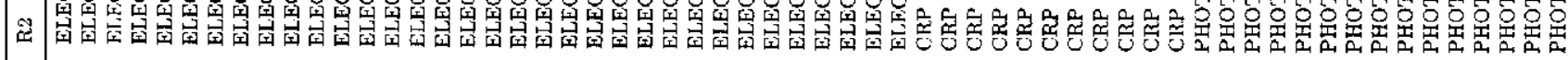

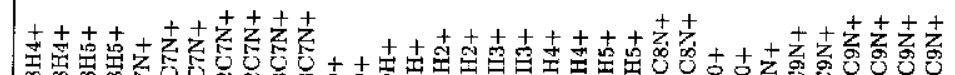

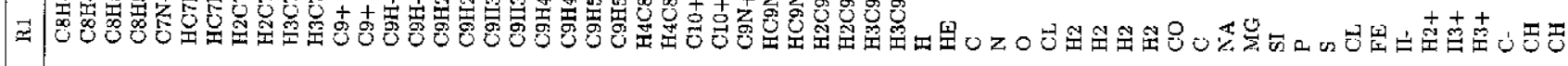

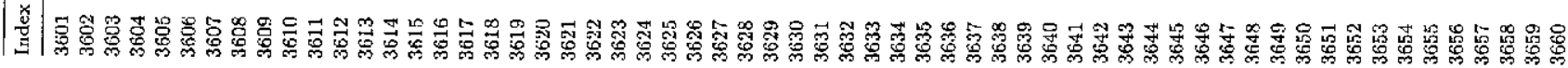


Table 4. continued
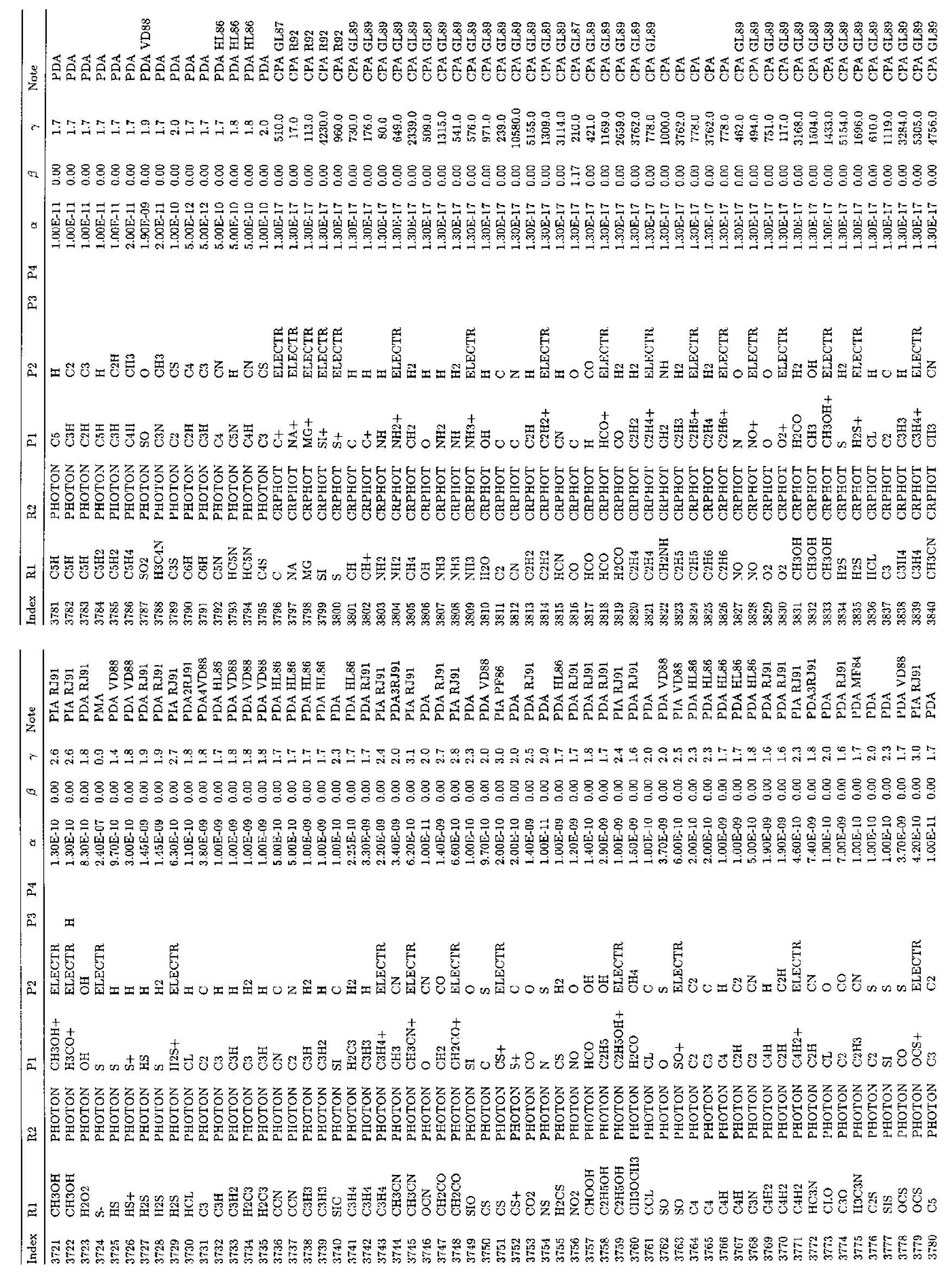
Table 4. continued

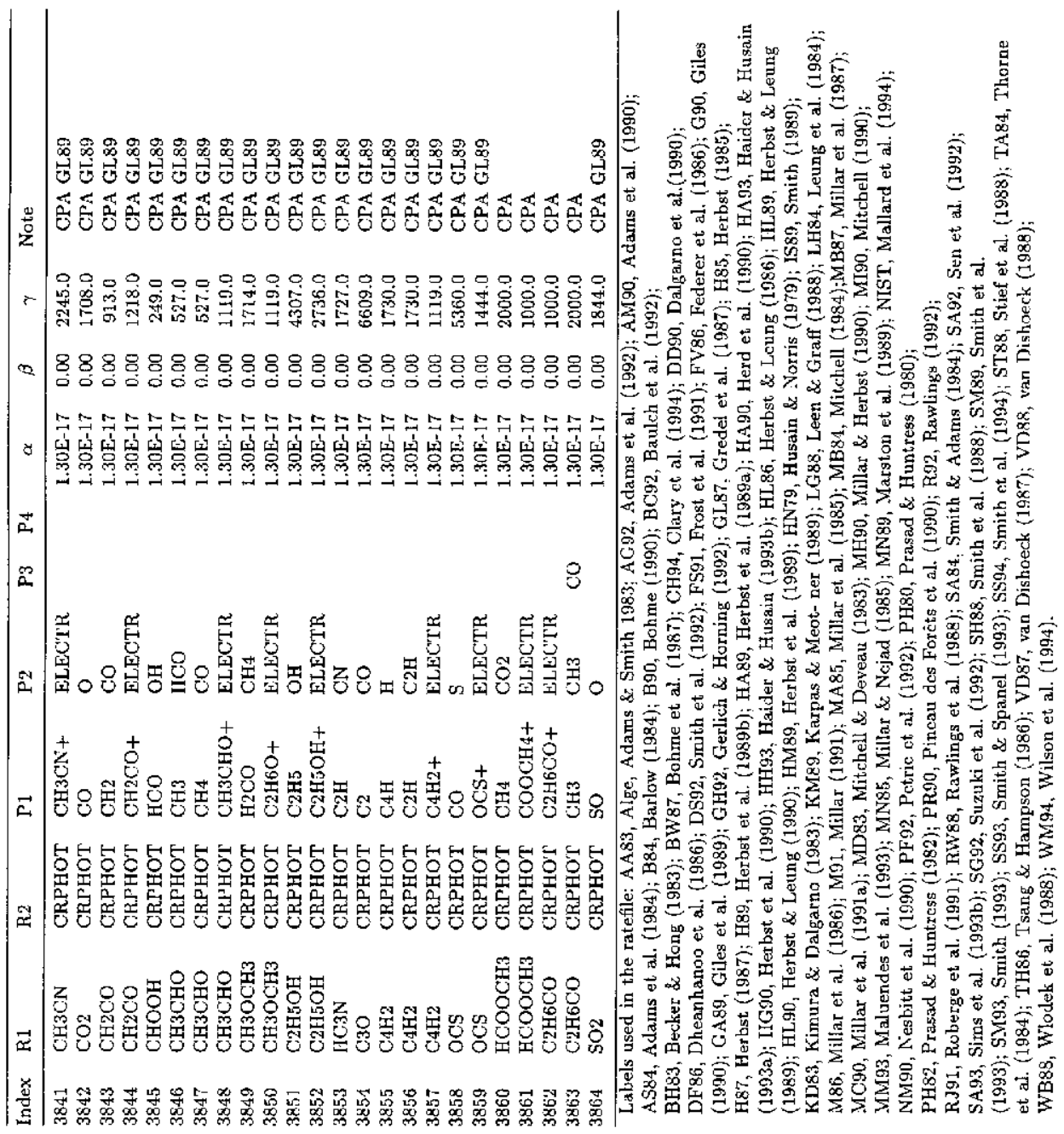

